The Geological Society of America

Digital Map and Chart Series 7

2010

\title{
Latest Quaternary glacial and periglacial stratigraphy, Wind River Range, Wyoming
}

\author{
Dennis E. Dahms* \\ Department of Geography, University of Northern Iowa, Cedar Falls, Iowa 50614-0406, USA \\ Peter W. Birkeland \\ Department of Geological Sciences, University of Colorado, CB 399, Boulder, Colorado 80309-0399, USA \\ Ralph R. Shroba \\ U.S. Geological Survey, M.S. 980, Denver Federal Center, Denver, Colorado 80225-0046, USA \\ C. Dan Miller \\ U.S. Geological Survey, Cascades Volcano Observatory, 5400 MacArthur Boulevard, Vancouver, Washington 98661, USA \\ Rolf Kihl \\ INSTAAR, University of Colorado, CB 450, Boulder, Colorado 80309-0450, USA
}

\begin{abstract}
We use relative dating criteria to document post-depositional alteration of till and periglacial deposits, and to map these deposits as facies of four allostratigraphic units (alloformations) in the Wind River Range. The alloformations are composed of till as well as rock-glacier, protalus-rampart, and rock fall deposits of latest Pleistocene and Holocene age. These deposits record paleoclimatic events over the past ca. 12.8 ka that influenced geomorphic processes in and near cirques and heads of glacial valleys of the Wind River Range. All of the type areas are on till. The oldest alloformation is the Temple Lake. Progressively younger units are the Alice Lake and Black Joe. The youngest unit is the Gannett Peak. Radiocarbon and cosmogenic radionuclide analyses provide numeric age control for these deposits. Combined numeric and relative age-data suggest the following broad age estimates for these alloformations: the Temple Lake is coeval with the Younger Dryas climate event (ca. 12,800-11,500 yr B.P.); Alice Lake is $>4500$ years old (ca. 6000 yr B.P.); Black Joe is ca. 1900 yr B.P. (minimum); and Gannett Peak is ca. 750-150 years old.
\end{abstract}

Keywords: Wyoming, Rocky Mountains, Wind River Range, Quaternary, glacial stratigraphy, relative dating.

\footnotetext{
*dennis.dahms@uni.edu

Dahms, D.E., Birkeland, P.W., Shroba, R.R., Miller, C.D., and Kihl, R., 2010, Latest Quaternary glacial and periglacial stratigraphy, Wind River Range, Wyoming: Geological Society of America Digital Map and Chart Series 7, 46 p., doi: 10.1130/2010.DMCH007.TXT. For permission to copy, contact editing@ geosociety. org. $@ 2010$ The Geological Society of America.
} 


\section{INTRODUCTION}

Despite many investigations since the late 1940s (Richmond, 1948), uncertainties persist concerning the latest Pleistocene and Holocene glacial and periglacial successions of the Wind River Range in west-central Wyoming. These uncertainties include the number of post-Pinedale glacial advances, the ages of these advances, and the valley-to-valley correspondence of their associated deposits. In order to help resolve these uncertainties, we mapped glacial and periglacial deposits in cirques and valleys in three extensive areas in the Wind River Range (Fig. 1). Our revised stratigraphy is based on mapping and data presented in this report. Until revisions by Dahms and Birkeland (2000) and Dahms (2002), the stratigraphic nomenclature used for postPinedale glacial and periglacial successions in a portion of the Wind River Range was borrowed from localities in Colorado, and did not reflect the findings of work done in the range. Since the range contains the type localities of the Pinedale and Bull Lake glaciations as well as those of two of the four post-Pinedale glacial events (Gannett Peak and Temple Lake) identified in the Wind River Range (Mears, 1974; Dahms, 2002, 2004a, 2004b, Dahms et al., 2003), we suggest that the type localities for deposits of the other two glacial events should also be described from deposits in the same range. We use various radiocarbon and cosmogenic dates to suggest ages for these deposits.

Three main areas of the Wind River Range were selected for study (Fig. 2). P.W. Birkeland and C. Dan Miller did the greater part of their fieldwork in the early 1970s. They concentrated on two areas in the southern and middle parts of the range, extending from Temple Peak on the south to just north of Baptiste and Grave Lakes on the north. These areas are at an altitude of $\sim 3100-3600 \mathrm{~m}$. They also worked in the northern part of the range at the termini of the Gannett and Dinwoody glaciers ( $\sim 3200-3600 \mathrm{~m})$. A minor amount of their work was published previously in Miller and Birkeland (1974). Dahms worked in the Stough Creek Basin and Deep Lake areas in the southern part of the range in the 1990s. Parts of this work were previously published in Dahms (2002). This report makes available previously unpublished data and provides a synthesis of our work in this key area of the Wind River Range.

In this report, all map units are informal allostratigraphic units (North American Commission on Stratigraphic Nomenclature, 1983) and correspond to the nomenclature of Dahms and Birkeland (2000) and Dahms (2002). For convenience, the tills of our four alloformations are referred to (from youngest to oldest) as Gannett Peak till, Black Joe till, Alice Lake till, and Temple Lake till. These tills at their type localities are referred to as type Gannett Peak till, type Black Joe till, type Alice Lake till, and type Temple Lake till. The moraine at the type locality of the Temple Lake till is referred to as the type Temple Lake moraine. Although Gannett Peak Till and Temple Lake Till are considered to be formal lithostratigraphic units, they were inadequately described (Richmond, 1957, 1965) and cannot be distinguished from other nearby till units on the basis of their lithologic characteristics. In this report we re-describe these two units and treat them as informal allostratigraphic units. As used in this report, the terms neoglaciation and neoglacial are informal terms that refer to a period of glacier growth and expansion in cirques in the western United States that began after the Altithermal (ca. 7500-5500 yr B.P.) and ended 150 years ago. Likewise, the term early Neoglacial is an informal term that has been used to refer to deposits that accumulated during the initial advance of neoglaciation.

The most important findings of our work are $(i)$ clear evidence for four post-Pinedale glacial advances preserved in many of the alpine valleys of the Wind River Range and (ii) the presence of a Younger Dryas glacial record, which in turn suggests that the Younger Dryas was a global-scale event whose signal was recorded in a region far from the Atlantic Ocean.

\section{BACKGROUND}

\section{Stratigraphy}

Hack (1943) and Moss (1949, 1951b) originally identified deposits corresponding to two post-Pinedale glacial events. From the geomorphic relations of deposits near Temple Lake, their early work shows that $(i)$ the deposits of their Temple Lake moraine predate the Altithermal (early Holocene, pre-neoglacial warm period) and (ii) their younger moraines correspond with their Little Glaciation (e.g., Little Ice Age). Richmond (1962, $1965)$ later used similar relative-age criteria as well as soils data to revise their interpretations. He identifies two separate Temple Lake moraines ("a" and "b") and considers them to be the products of older and intermediate neoglacial (post-Altithermal) advances in the range. Richmond also changed the name of Holmes and Moss' Little Glaciation to Gannett Peak. He designated till of the moraine at the foot of Gannett Glacier near Gannett Peak in the northern Wind River Range as the type locality for deposits of the Little Ice Age (Richmond, 1962, 1965; Benedict, 1968; Birkeland et al., 1971).

Currey (1974) reports a ${ }^{14} \mathrm{C}$ age of $6500 \pm 230 \mathrm{yr}$ for material from the bottom of a bog in the valley of Rapid Creek near Temple Lake. This was the first radiocarbon age reported from the alpine glacial sequence in the Wind River Range and, due to its position up-valley of the Temple Lake moraine, demonstrates that the deposits which comprise the moraine are preAltithermal. Concurrent with Currey's 1974 work, Miller and Birkeland (1974) present two lines of evidence concerning the Wind River Range alpine glacial succession. First, they present multiple relative-age criteria to corroborate Currey's evidence that deposits of the Temple Lake moraine at its type locality are pre-Altithermal. Second, they suggest that glacial deposits intermediate in age between the earliest neoglacial deposits (their "early Neoglacial") and the latest (Gannett Peak = Little Ice Age) represent an intermediate neoglacial ice advance. Miller and Birkeland (1974) introduce the term Audubon-equivalent for the intermediate unit to reflect its similarity to the Audubon 


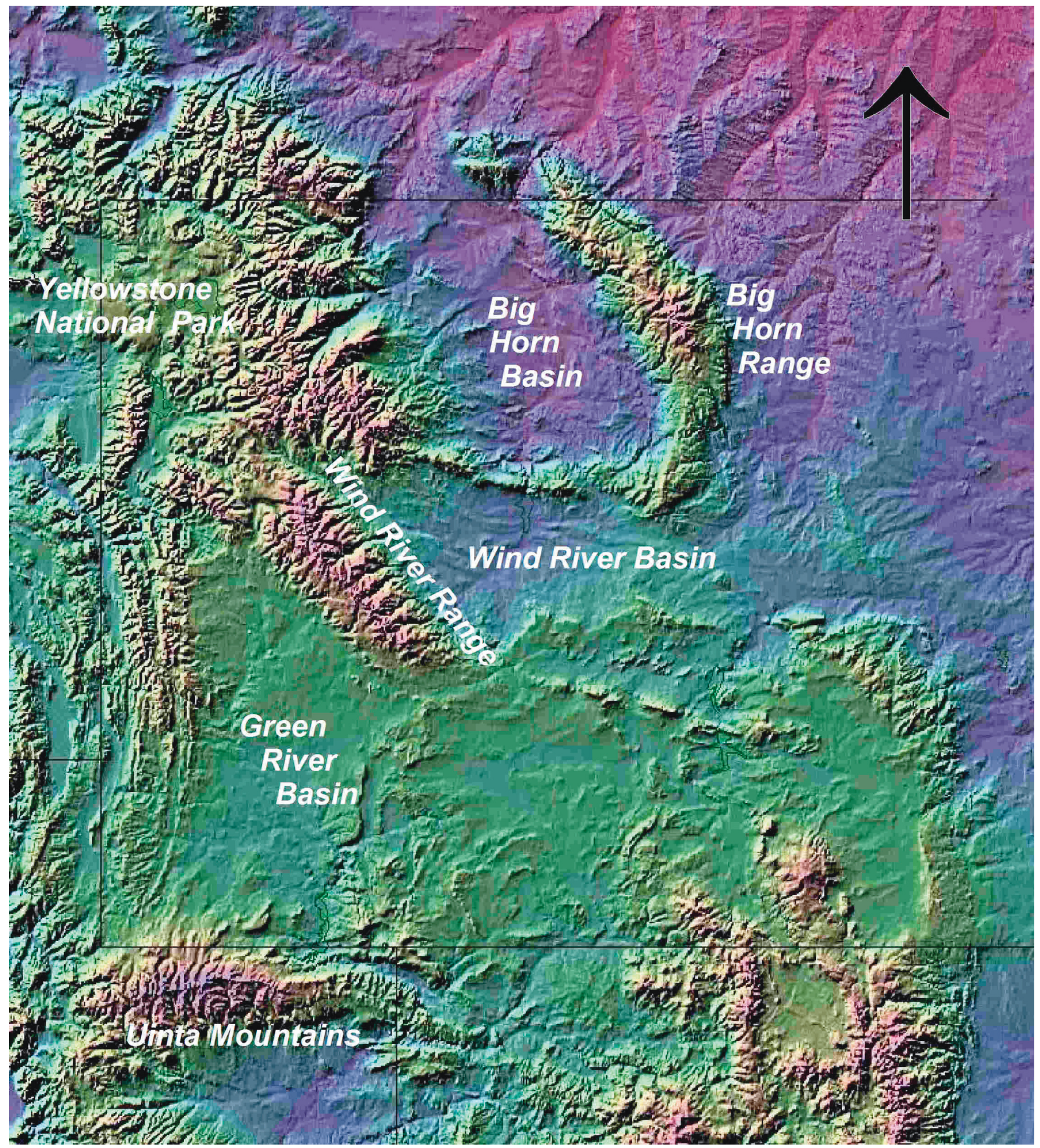

Figure 1. Digital image of the Middle Rocky Mountain region showing the location of the Wind River Range in relation to other important mountain ranges and features. Image from Chalk Butte, Inc., Boulder, Wyoming. 


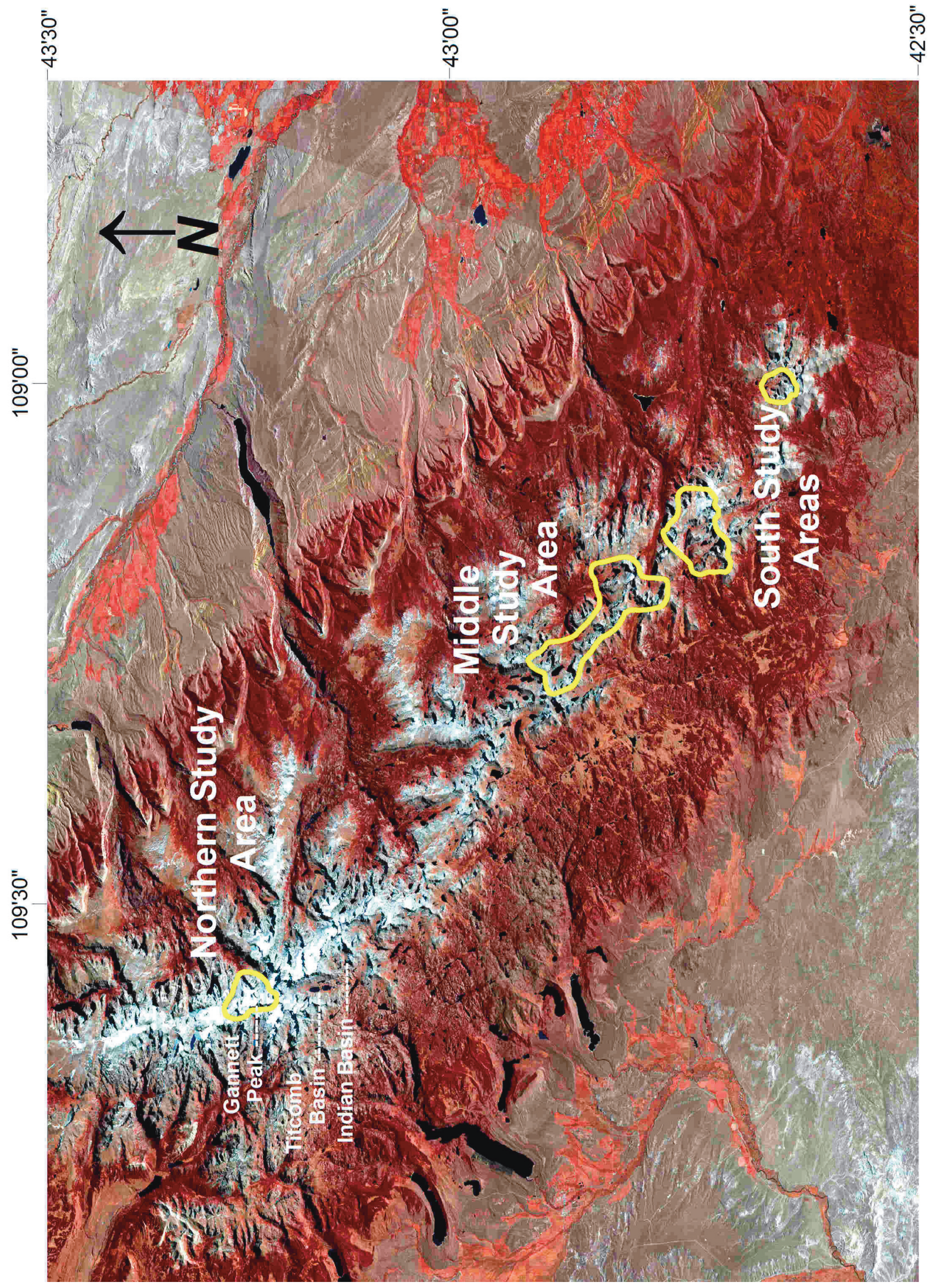

음

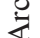

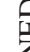

$\stackrel{2}{0}$

츨

苣

อे

ज

ம்

完

光

ลำ

.

힌

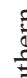

売

$\frac{0}{7}$

.

ह

z

I

$\Xi$

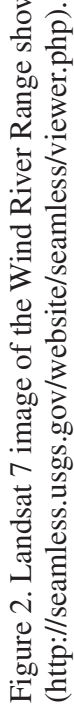


unit identified in the Colorado Front Range by Mahaney (1972). Thus, Miller and Birkeland (1974) describe a sequence of deposits in the valley of Rapid Creek near Temple Lake that corresponds to four episodes of post-Pinedale glacial activity in the Wind River Range (Temple Lake plus early, intermediate, and latest neoglacial advances).

In the northern Wind River Range, Mahaney (1978, 1984a, 1984b, 1987) identifies glacial deposits in and near Titcomb Basin which he correlates with the threefold succession of neoglacial deposits described by Miller and Birkeland (1974). Correlations of Mahaney's stratigraphic units with those near Temple Lake and elsewhere in the Wind River Range remain uncertain. To make such a correlation between our work and that of Mahaney would have required extensive field visits that we did not make. Davis (1988) provides a concise discussion of the stratigraphic issue concerning glacial deposits of Holocene age in the Wind River Range and elsewhere in the western United States.

One uncertainty concerns the age of the deposits that comprise the Temple Lake moraine at Temple Lake. Despite the evidence presented by Currey and by Miller and Birkeland (see above), Mahaney $(1978,1988)$ considers the age of these deposits questionable and proposes to abandon the term Temple Lake. This proposal was rejected by his peers who, for many reasons, continue to use the term (Davis, 1988; Zielinski and Davis, 1987, 1988; Dahms, 2002). The uncertainty concerning the age of Temple Lake deposits apparently was resolved by Zielinski and Davis (1987). They present ${ }^{14} \mathrm{C}$ ages for lake sediments down valley of the Temple Lake moraine of Hack (1943) and Moss (1951a, 1951b) that place the deposition of the deposits that comprise the moraine within the younger Dryas chron (Zielinski and Davis, 1987; Alley et al., 1993). Thus, Temple Lake deposits in the Wind River Range are considered to be the products of the latest Pleistocene (post-Pinedale) glacial activity in the Middle Rocky Mountains. Gosse et al. (1995a; revised in Gosse et al., 2003) subsequently present a series of ${ }^{10} \mathrm{Be}$ and ${ }^{26} \mathrm{Al}$ exposure ages from boulders on moraines in Titcomb Basin that were mapped by Mahaney as late Pinedale. The boulders have revised mean ages (after correction for snow cover) of $12.9 \mathrm{ka}$ $\left({ }^{10} \mathrm{Be}\right)$ and $13.1 \mathrm{ka}\left({ }^{26} \mathrm{Al}\right)$, which fall within the Younger Dryas chron (Alley et al., 1993).

Mahaney (1984b) suggests that a set of moraines below Harrower Peak in Indian Basin (adjacent to Titcomb Basin) represent an early post-Altithermal advance. He proposes that these deposits be considered the type locality for all tills previously correlated with the early Neoglacial advance in the Wind River Range and that the early Neoglacial deposits be termed Indian Basin. This proposal generally was ignored, since the term early Neoglacial had been in common use for several years and no change had been made in the unit's stratigraphic position (Davis, 1988). Furthermore, the cosmogenic ages reported by Gosse et al. (1995a, 1995b, 2003) show that in Titcomb Basin moraines mapped by Mahaney as purportedly early Neoglacial and Audubon-equivalent deposits are older than $10 \mathrm{ka}$. Thus, the deposits in Titcomb Basin that Mahaney would correlate with
Indian Basin clearly are not early Neoglacial in age; some of Mahaney's Indian Basin deposits are older than $10 \mathrm{ka}$. In support of the cosmogenic ages, P.T. Davis (1994, oral commun.) suggested the equilibrium line altitude (ELA) for Mahaney's (1984a, 1984b) Indian Basin moraine below Harrower Peak is too low for the moraine to be considered early Neoglacial in age and that it should be considered correlative to Temple Lake till at its type locality (Hack, 1943; Moss, 1951a, 1951b). Until this controversy is resolved, we prefer to use the name Alice Lake, a name introduced by Miller and Birkeland in the 1970s.

Later work by Dahms (2002 and new data in this report) in Stough Creek Basin and Deep Lakes cirque, south and east, respectively of Temple Lake, identifies deposits that correspond with the glacial succession identified by Miller and Birkeland (1974). Multiple relative-age criteria were used to identify glacial deposits in Stough Creek Basin that correlate with the Temple Lake, early Neoglacial, Audubon-equivalent, and Gannett Peak glacial events. Two preliminary cosmogenic nuclide ages from boulders on lateral moraines (Dahms, 2002) along with about 20 unpublished ages from samples of polished and striated bedrock (D. Fabel, 2009, written commun.) suggest that ice was absent from the floor of upper (southern) Stough Creek Basin by ca. $14 \mathrm{ka}$. These ages add credence to the interpretation that tills in moraines mapped as Temple Lake upvalley from the cosmogenic age sites are indeed post-Pinedale. Also, the multiple relative-age characteristics of the tills in Stough Creek Basin match those described on other deposits considered to be of Temple Lake age in the Wind River Range (Dahms, 2002; data in this report).

\section{Paleoecology and Paleoclimate}

The correspondence between glacial stratigraphy and limited paleoecological records for the Wind River Range is poorly constrained. Data on climate change recorded in lake sediments are only available from lakes in two alpine valleys in the range. Lake records from the valley of Rapid Creek near Temple Lake (Fall et al., 1995; Zielinski, 1989; Zielinski and Davis, 1987) and from Titcomb Basin (Gosse et al., 1999) suggest that as few as three or as many as seven millennial-scale climate variations may have occurred in the range since ca. 18,000 yr B.P. Accelerator mass spectrometry ${ }^{14} \mathrm{C}$-dated sediments from these lakes link at least three neoglacial climate events to specific moraines and their associated deposits. Although the total number and ages of post-Pinedale glacial events recorded in the sediment, organic matter content, and pollen data from the Titcomb Basin lakes remain unknown, preliminary analyses suggest five or six major post-Pinedale climate-change events, with neoglaciation possibly beginning by 6000 cal yr B.P. (Gosse et al., 1999; J.C. Gosse, 2000, written commun.). Data from lake sediment cores for the valley of Rapid Creek near Temple Lake suggest that the onset of neoglaciation occurred more recently ca. $3300{ }^{14} \mathrm{C}$ yr B.P. (Zielinski and Davis, 1989; Fall et al., 1995). Despite the above studies, much uncertainty remains concerning the onset and timing of neoglacial climate events in the Wind River Range. 
Lake sediment records from Yellowstone National Park provide the most complete record of late Pleistocene and Holocene climate change in the Middle Rocky Mountain region. Climate proxies in Yellowstone National Park correspond most directly to large-scale controls (e.g., seasonal cycles of insolation, atmospheric composition, and atmosphere-ocean interactions) varying over centennial-to-millennial periods (Meyer, et al., 1995; Millspaugh and Whitlock, 1995, 2003; Millspaugh et al., 2000; Mock and Brunelle-Daines, 1999; Whitlock and Bartlein, 1993, 2004). Evidence in these sediments for decadal-to-centennial climate change is not as clear.

\section{SETTING AND ENVIRONMENTAL FACTORS}

The Wind River Range is located in the Middle Rocky Mountains of west-central Wyoming (Fig. 1). The range is $\sim 225 \mathrm{~km}$ long and $48 \mathrm{~km}$ wide. The Continental Divide follows the crest of the range for a distance of ca. $200 \mathrm{~km}$. The range contains 47 of the 50 peaks in Wyoming above 4,000 m and the 63 glaciers in the range represent the largest total area of glaciers of any state in the Rocky Mountains of the conterminous U.S. (Denton, 1975). Most glaciers occupy northand east-facing cirques on the eastern side of the Continental Divide. The largest glaciers are east of the Continental Divide in the northern part of the range (e.g., Gannett, Dinwoody, Fremont, Knifepoint, and Bull Lake glaciers). Snow distribution in the range is most likely due to wind loading of snow (Meier, 1951), because most glaciers lie in either north- or east-facing cirques or are on broad uplands east of the divide (Meier, 1951; Naftz, 1993). Annual precipitation is locally as much as 700$1000 \mathrm{~mm}$ near the Continental Divide (Lowham, 1988; Marston et al., 1991; Naftz, 1993).

\section{Structure and Bedrock}

The Wind River Range is a large asymmetric anticline-like structure uplifted along the Laramide-age Wind River Thrust. The range has a core composed of Archean-age crystalline rock that underlies much of the study area (Hulsebosch, 1993). Rocks underlying the northern study area (Fig. 2) commonly consist of migmatitic gneiss associated with the 2.67-Ga Bridger batholith and 2.55 Ga quartz diorite plutons (Granger et al., 1971; Frost et al., 2000). The gneiss typically contains quartz, feldspar, and biotite, whereas the migmatite consists of the latter rock type as well as injected and melted and recrystallized granitic material. The quartz diorite consists of oligoclase or andesine, biotite, hornblende, quartz and minor amounts of microcline. Mediumgrained diabase dikes that contain labradorite, augite, and pigeonite cut the migmatites.

Rocks of the middle study area consist most commonly of calc-alkaline charnockitic plutons of the Louis Lake batholith $(2.63 \mathrm{Ga})$ that consist of minor diorite, quartz diorite, granodiorite, and granite (Frost et al., 2000). The migmatitic gneiss and Late Archean plutons described above for the north also are pres- ent locally. The most common rock type in the southern study area is weakly metamorphosed porphyritic quartz monzonite of the 2.63-Ga Louis Lake batholith (Pearson et al., 1971; Frost and Frost, 1993; Frost et al., 2000). The quartz monzonite typically contains phenocrysts of microcline in a groundmass of oligoclase, quartz, biotite, and locally, hornblende. Frost et al. (2000) also describes the Louis Lake batholith as a charnockite.

\section{Environmental Conditions}

Little instrumental data are available concerning the modern climate of the Wind River Range. Alpine sites provide most of the modern data. The period of maximum total precipitation is late spring through early summer; summer thundershowers are common. Long-term mean annual precipitation data are not available, but it is thought to be similar to that of the Front Range of Colorado, which receives nearly $100 \mathrm{~cm}$ of precipitation annually (Barry, 1973) in the alpine above $3450 \mathrm{~m}$. During a 122day sampling period in the summer of 1992 (June-October) two microclimate stations located at an altitude of $3383 \mathrm{~m}$ on Roaring Fork Mountain (to the east of Stough Creek Basin near the southern margin of the range) recorded summer air temperatures of 5-9 ${ }^{\circ} \mathrm{C}$ within $10 \mathrm{~cm}$ of the ground surface (R.W. Scott, 1999, written commun.). Daily maxima ranged from $10{ }^{\circ} \mathrm{C}$ to $16{ }^{\circ} \mathrm{C}$ and daily minimums ranged from $0{ }^{\circ} \mathrm{C}$ to $3{ }^{\circ} \mathrm{C}$.

Ice cores taken from Fremont glacier in the northern Wind River Range were examined by the U.S. Geological Survey for evidence of late-Holocene climatic and hydrologic changes (Naftz, 1993; Naftz and Miller, 1992; Naftz and Smith, 1993; Naftz et al., 1993, 2002). The records are relatively short, covering the last 300-350 yr, but they provide valuable information about annual hydrologic change. Ice-core data from July 11, 1990 to July 10, 1991 on Upper Fremont Glacier near the northern study area indicate the mean annual air temperature was $-6.9{ }^{\circ} \mathrm{C}$, with a minimum air temperature of $-35.9{ }^{\circ} \mathrm{C}$ and a maximum temperature of $13.3^{\circ} \mathrm{C}$. (Naftz and Miller, 1992). The mean daily temperature often exceeded $0{ }^{\circ} \mathrm{C}$ from about Julian day 160 through Julian day 260 (Naftz and Smith, 1993). These measurements indicate generally colder conditions exist between 3500 and $4000 \mathrm{~m}$ in the Wind River Range than the $-3.5^{\circ} \mathrm{C}$ mean annual temperature extrapolated from Mahaney’s (1978) lapse rate calculations for Titcomb Basin. Average air temperatures during storms, reconstructed from ice-core data from Upper Fremont Glacier, are estimated to have increased $\sim 3.5^{\circ} \mathrm{C}$ from the mid-1960s to the early 1990 s and nearly $5^{\circ} \mathrm{C}$ over the last $\sim 150$ years, between the end of the Little Ice Age (Gannett Peak glaciation) and the early 1990s (Naftz et al., 2002).

In 1951, the firn limit on glaciers in the range was $\sim 3660 \mathrm{~m}$ (Meier, 1951). The ELA is now generally higher in the Wind River Range. In 1991, the observed firn limit on Upper Fremont Glacier was $3990 \mathrm{~m}$ (Naftz et al., 1993). This limit is near the estimate of $3952 \mathrm{~m}$, derived by using an accumulation area ratio of 0.6 combined with the margins of the largest modern glaciers in the range (Naftz, 1993; 2005, written commun.). 


\section{FACIES OF ALPINE DEPOSITS IN THE WIND RIVER RANGE}

In most study areas our alloformations consists of several map units (facies), including till, protalus-rampart, rock-glacier, and rockfall deposits (Fig. 7; Table 1). Only for the Gannett Peak and Dinwoody glaciers (Fig. 3) did we map Gannett Peak deposits as an undivided unit, as we were unable to distinguish genetic units. Dahms mapped only till facies for post-Pinedale deposits in Stough Creek Basin and Deep Lakes Valley (Fig. 6).

Tills and rock-glacier deposits are the most common deposits mapped in this study (Figs. 3-6). In all the areas we mapped, most former and present glaciers and rock glaciers moved or are moving into the quadrant between north and east, off of steep cirque floors or valley walls. In the middle study area, all till units are present in cirques, some in front of modern glaciers (Fig. 4). Gannett Peak, Black Joe, and Alice Lake rock-glacier deposits are locally present. Protalus-rampart deposits are less abundant; those of Gannett Peak, Black Joe, and Alice Lake ages are recognized and are most common in the Cirque of the Towers. In the cirques of Stough Creek Basin, protalus-rampart deposits locally are common, but were not mapped (Fig. 6).

Till is the most common deposit in the central part of the southern study area, where till of four ages are locally present. Rock-glacier deposits are locally present; protalus-rampart deposits of equivalent ages are less abundant. Near the western and eastern limits of the southern study area, in (presumably) slightly drier microclimates, rock-glacier deposits are more common. Age ranges for rock glaciers are greatest in the eastern portion of the area.

Till is commonly recognized by its landform morphology, characterized by the presence of one or more arcuate ridges, convex in the direction of the ice flow. Large clasts in Gannett Peak and Black Joe tills are at least slightly rounded due to abrasion during glacial transport (e.g., Reheis, 1975), while similarsized clasts in the Alice Lake, Temple Lake, and Pinedale tills are progressively more rounded, reflecting increasing transport distance(s) and age. Sand and finer materials generally fill the interstices between clasts in and on the older tills so that these deposits commonly have a nearly continuous cover of tundra vegetation (chiefly alpine grasses and herbs). The Gannett Peak and Black Joe deposits generally have smaller amounts of interstitial material to support alpine vegetation and provide parent material for soils.

Rock-glacier deposits are tongue- or lobe-shaped bodies of angular rock rubble, with little or no matrix, that commonly merge upslope with talus (Wahrhaftig and Cox, 1959; Washburn, 1979; Giardino et al., 1987). Rock glaciers show morphological evidence of downslope movement. Ridges and furrows are common on rock glacier deposits. Usually, they are curved and are oriented concave toward the cirque headwall (source) as a result of differential flowage. Steep fronts or sides of rock glaciers are commonly at or near the angle of repose. The junction angle between the front and top of active rock glaciers is sharp, whereas that of inactive rock glaciers is rounded. Ages are assigned to rock-glacier deposits on the basis of relative-age criteria observed on the clasts, irrespective of whether the rock glacier is active or inactive.

The surface morphology of protalus-rampart deposits is similar to that of moraines, but stones on the latter are angular, interclast fines are absent, and the deposits are located close to talus along cirque headwalls (e.g., Washburn, 1979). Locally, protalusrampart deposits were difficult to distinguish from till deposited by small glaciers. We mapped protalus-rampart deposits in catchment areas too small to have contained a glacier.

Rockfall deposits are composed chiefly of angular blocks that lack interstitial matrix. They commonly form sheet-like deposits. Most deposits lie at distances from the bases of cirque headwalls that suggests they moved as high velocity rockfalls.

\section{RELATIVE-AGE METHODS}

It is often difficult to obtain numerical ages for glacial and periglacial deposits in the Rocky Mountains because of the scarcity of organic matter associated with deposits. Thus, workers differentiate and correlate deposits based chiefly on postdepositional characteristics (soils, rock-weathering, and biological properties) that can be measured in the field (see Beschel, 1957; Benedict, 1967, 1968; Birkeland, 1973; Birkeland et al., 1979, 1987; Colman et al., 1987; Dahms 2002). Because postdepositional properties change progressively over time, suitable methods at selected sites can be utilized to recognize and distinguish map units. Wherever possible, we assign ages to our stratigraphic (map) units based on the most recent published and unpublished numeric ages.

Semiquantitative relative-age (RA) methods are used to differentiate among, and provide approximate ages for, deposits in this study (e.g., Birkeland et al., 1979). Lichenometry, rock weathering, thickness of loess mantle, and soil-profile development are used in combination to characterize deposits because each method provides only a minimum age estimate and each method has a limited time span over which it is useful for estimating ages (Birkeland, 1973, figure 11 therein). At some sites, different RA methods suggest different ages for the same deposita very real problem when using RA methods in stratigraphic studies. One must make a judgment as to which method(s) gives the most reliable indication of age. In most instances, we have taken the oldest indicated age as being closest to the true age because geomorphic processes such as spalling occasionally may make a deposit appear younger than its true age. The ranges in relative-age data for recognizing and distinguishing map units are described in Table 1.

Moss (1951a, 1951b) first demonstrated the usefulness of RA methods for differentiating late Pleistocene and Holocene tills in the Wind River Range. Additional RA data, numeric ages, and correlation of deposits in the Wind River Range are provided by Richmond (1965, 1986), Currey (1974), Dahms (2002, 2004b), Dahms et al. (2003), Davis et al. (1998), Fall et 
TABLE 1. DESCRIPTION OF MAP UNITS AND DESCRIPTION OF RELATIVE-AGE CRITERIA FOR THEIR RECOGNITION (NORTHERN, MIDDLE, AND SOUTHERN AREAS)

Qg Gannett Peak alloformation (latest Holocene). Deposits of this alloformation are closest to the cirque headwalls and valley sidewalls. Till, rock-glacier, protalus-rampart, and rockfall deposits are included in this unit. Little post-depositional alteration has occurred (Tables 2-6). Vegetation is generally absent. Lichen cover is $<10 \%$ for any boulder and $<1 \%$, on average, for the deposit. The range in lichen diameters is as follows: Rhizocarpon geographicum, s.I., absent to $35 \mathrm{~mm}$; Lecanora thomsonii, absent to 95 $\mathrm{mm}$; Lecidea aspicilia, absent to $84 \mathrm{~mm}$; Lecidea atrobrunnea, absent to $72 \mathrm{~mm}$; and C. elegans, absent to $70 \mathrm{~mm}$ The deposits show no rock weathering, and loess is absent. Soil development is limited to $6 \mathrm{~cm}$ or less of very weak oxidation, and/or $2 \mathrm{~cm}$ of A-horizon development (Tables 2, 3). Only at Dinwoody Glacier (Fig. 3) were we able to differentiate younger (Gpty) and older (Gpto) Gannett Peak tills, and the separation there was based only on lichen data (Tables 4-6).

Qbj Black Joe alloformation (late Holocene). Deposits of this alloformation usually are immediately downvalley or downslope of those of the Gannett Peak alloformation. Till, rock-glacier, and protalus-rampart deposits are included in this unit and exhibit sufficient postdepositional alteration to be readily differentiated from both younger and older deposits (Tables 2-6). Vegetation is generally absent, or covers $<5-10 \%$ of the surface. Lichen cover per boulder ranges from $10 \%$ to $85 \%$, and cover for a site varies from $10 \%$ to about $65 \%$, but most deposits have an average lichen cover of $<40 \%$. Lichen diameters vary in size as follows: R. geographicum, s.I., $10-70$ mm; L. thomsonii, 60-171 mm; L. aspicilia, 40-190 mm; L. atrobrunnea, 30-176 mm; and C. elegans, 35-67 mm. Surface boulders are slightly weathered and characteristics vary as follows: feldspar phenocryst relief, 0-7 mm; oxidation, none to oxidized, but most are slightly oxidized; weathering, none to $88 \%$, but most sites have values of less than $~ 10 \%$; pitting, none to $35 \%$, and commonly the pits are quite subtle; and depth of pits, $0-40 \mathrm{~mm}$. A subtle, thin surface spalling was also recognized on some clasts. Loess is absent. Soils include A/Cox profiles, or just Cox horizons; the Cox horizons are subtle, and thicknesses range from 5 to $15 \mathrm{~cm}$.

Qal Alice Lake alloformation (middle Holocene). Deposits of this alloformation usually lie between those of the Black Joe alloformation (upvalley or upslope) and the Temple Lake alloformation (downvalley or downslope). Till, rock-glacier, protalus-rampart, and rockfall deposits are included in this unit. Sufficiently distinctive post-depositional alteration features are present to allow these deposits to be readily differentiated from those of the Black Joe alloformation, but there are some problems in differentiating the Alice Lake alloformation from the Temple Lake alloformation. Till of this alloformation may have a full alpine tundra vegetation cover. Lichen cover varies from $75 \%$ to $90 \%$ per boulder, and most boulders have a lichen cover of about $85 \%$. We have fewer data than for other alloformations on average lichen cover per deposit, but the range is $35 \%$ to $85 \%$. The range of thallus diameters is 5 to $138 \mathrm{~mm}$ for R. geographicum, s.l., with few thalli found at the lower end of the size range. The ranges of sizes for the other lichens are: L. thomsonii, 80-115 mm; L. aspicilia, 131-181 mm; and L. atrobrunnea, 79-215 mm. It should be noted, however, that the latter three lichen species probably reach senescence in a couple of thousand years and therefore are providing only information on the minimum age of deposits of this alloformation. Weathering is fairly well developed. The range in weathering parameters is as follows: feldspar phenocrysts, 10-20 mm relief; surfaces are slightly oxidized to oxidized, with the latter class dominant; weathered clasts range from $2 \%$ to $64 \%$, with most sites grouped toward the middle of the range; pitting, $15 \%$ to $66 \%$, and depth of pits, $35-120$ $\mathrm{mm}$, with most boulders pitted to depths $<100 \mathrm{~mm}$. This is the youngest deposit for which a surface layer of loess or mixed loess is present, and its thickness ranges from 0 to $33 \mathrm{~cm}$. The analyzed soils are mostly A/Bw or Bt/Cox profiles, with a B-horizon thickness range of 6-14 cm. Where the Cu horizon is encountered, it is at a depth greater than $12 \mathrm{~cm}$; for many soils, however, Cu material was not encountered in soil pits that ranged from 27 to $72 \mathrm{~cm}$ deep. For soils described in the field but not analyzed (Table 3), B-horizon thicknesses vary from 4 to $41 \mathrm{~cm}$, but most are $<30 \mathrm{~cm}$ thick. If the Cu horizon is present in shallow soils, it is at $15 \mathrm{~cm}$ or more depth.

QtI Temple Lake alloformation (latest Pleistocene). Deposits of this alloformation usually lie downvalley or downslope of those of the Alice lake alloformation. Till, rock-glacier, protalus-rampart, and rockfall deposits are included in this unit. Only a few post-depositional alteration features distinguish this alloformation from the Alice Lake alloformation (Tables 2-6). Vegetation (full cover) and lichen data ( $R$. geographicum diameter 60-141 mm) cannot be used to distinguish this unit from the Alice Lake alloformation because vegetation is often the same and lichens have reached nearly maximum diameters and percent cover on the Alice Lake deposits, or even on still younger deposits for some lichen species. Data on weathering features are as follows: surface clasts are oxidized; $17 \%$ to $84 \%$ of clasts are weathered and $>50 \%$ of the clasts are weathered on most deposits; $31 \%$ to $79 \%$ of the clasts are pitted; pit depths vary from 75 to $250 \mathrm{~mm}$, with most values $>100 \mathrm{~mm}$. Loess or loess mixed with local parent material varies in thickness from 0 to $46 \mathrm{~cm}$; loess is absent at only one site. The analyzed soils are A/Bt or Bw/Cox profiles (Table 2), with a B-horizon thickness that ranges from 11 to $36 \mathrm{~cm}$. Cu material was never encountered even though the soil pits ranged from 43 to $146 \mathrm{~cm}$ in depth. For soils described in the field (Table 3), the B-horizons vary in thickness from 6 to $50 \mathrm{~cm}$, and where Cu material was encountered, it is at a depth of 32 $\mathrm{cm}$ or more. Although there is considerable overlap in data between the Temple Lake and Alice Lake alloformations (Table 3), the two can best be distinguished on depth of pitting and B-horizon properties (especially thickness and color).

Qp Till of Pinedale glaciation (late Pleistocene). Pinedale glacial deposits mapped here have muted moraine morphology and lie immediately downvalley of deposits of the Temple Lake alloformation. Data for these deposits consist chiefly of soil profile development in Stough Creek Basin (data in Dahms, 2002) and isolated profiles elsewhere. Soils are A/Bt(Bw)/Cox under tundra or $\mathrm{A} / \mathrm{E} / \mathrm{Bs} / \mathrm{Cox}$ profiles under forest with B-horizon thicknesses that range from 10 to $46 \mathrm{~cm}$. Munsell colors often are $7.5 \mathrm{YR}$ hues under forest and less often under tundra. Cu material was encountered from 62 to $80 \mathrm{~cm}$. There is considerable overlap in data among the soil profiles developed under tundra on the Temple Lake alloformation and the Pinedale alloformation. 


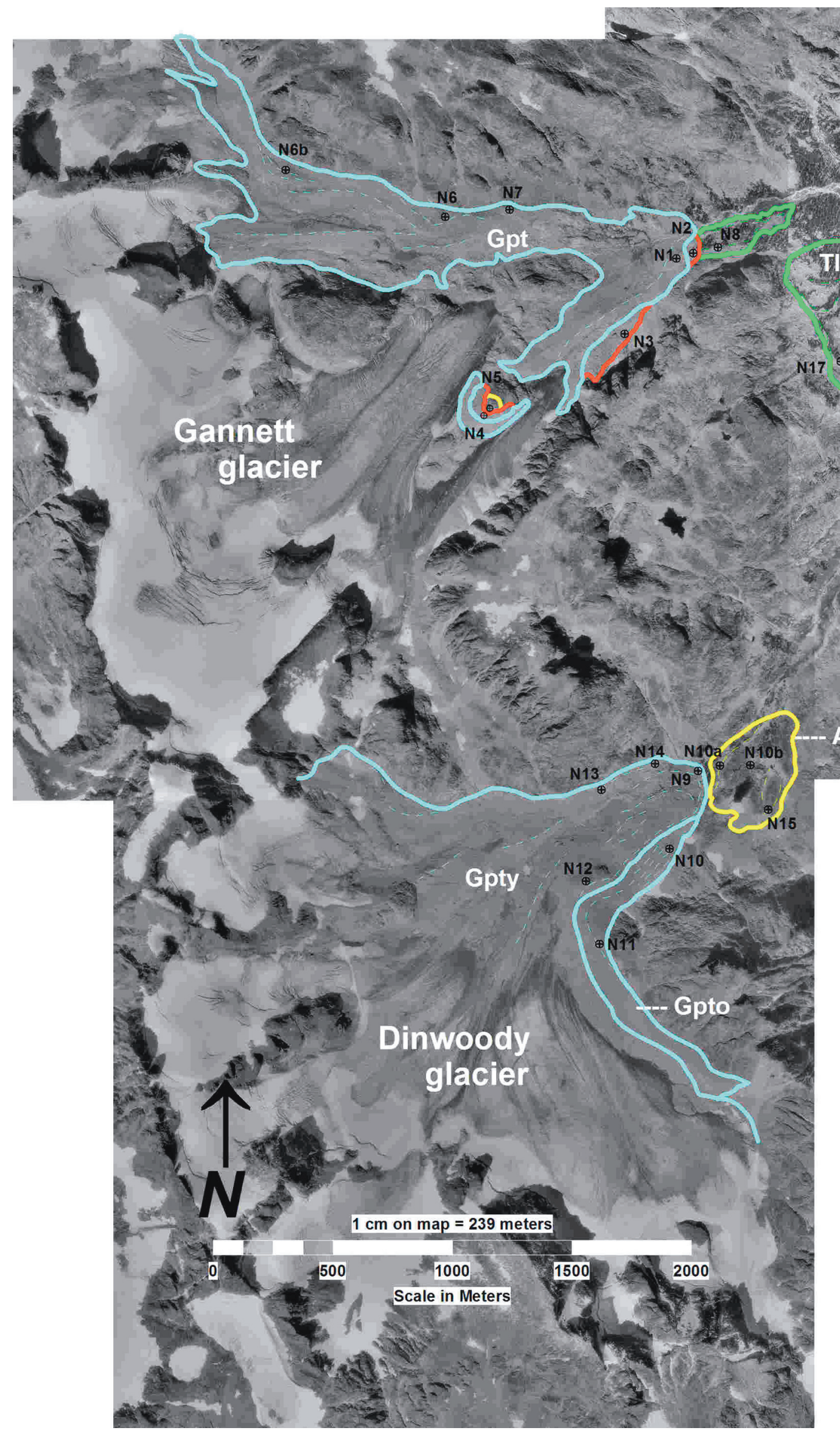

Figure 3. Map of the late Quaternary glacial and periglacial deposits in the northern area of the Wind River Range, near the termini of Gannett and Dinwoody glaciers. The image includes portions of the eastern Gannett Peak and western Wind River Peak U.S. Geological Survey digital orthophoto quadrangles. USGS vertical air photographs ECE-2-93 (1957), ECE-4-42 (1958), and ECE-4-44 (1958) were used as the original base for the map units. Explanation of colors, lines, and symbols given in Figure 7. 


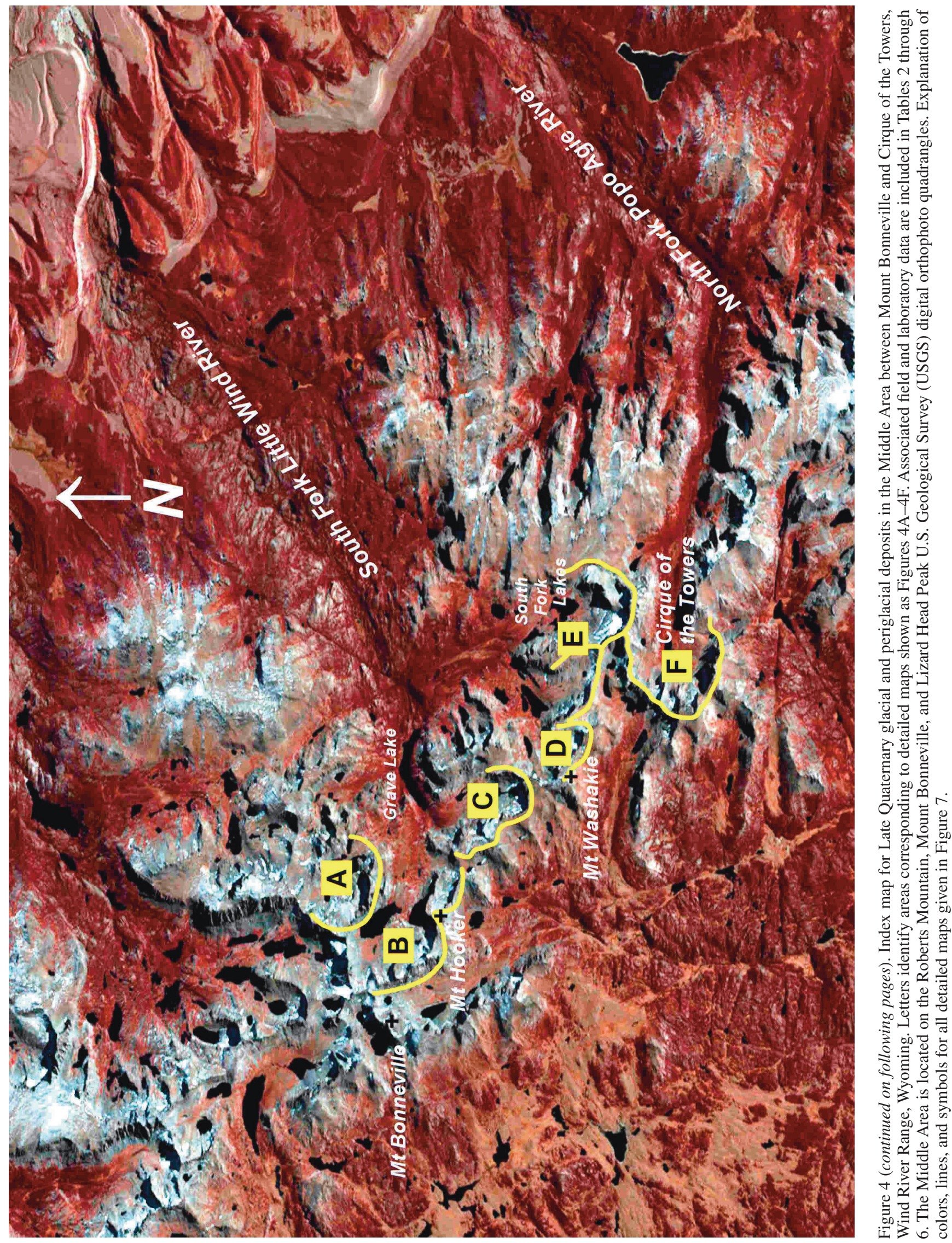




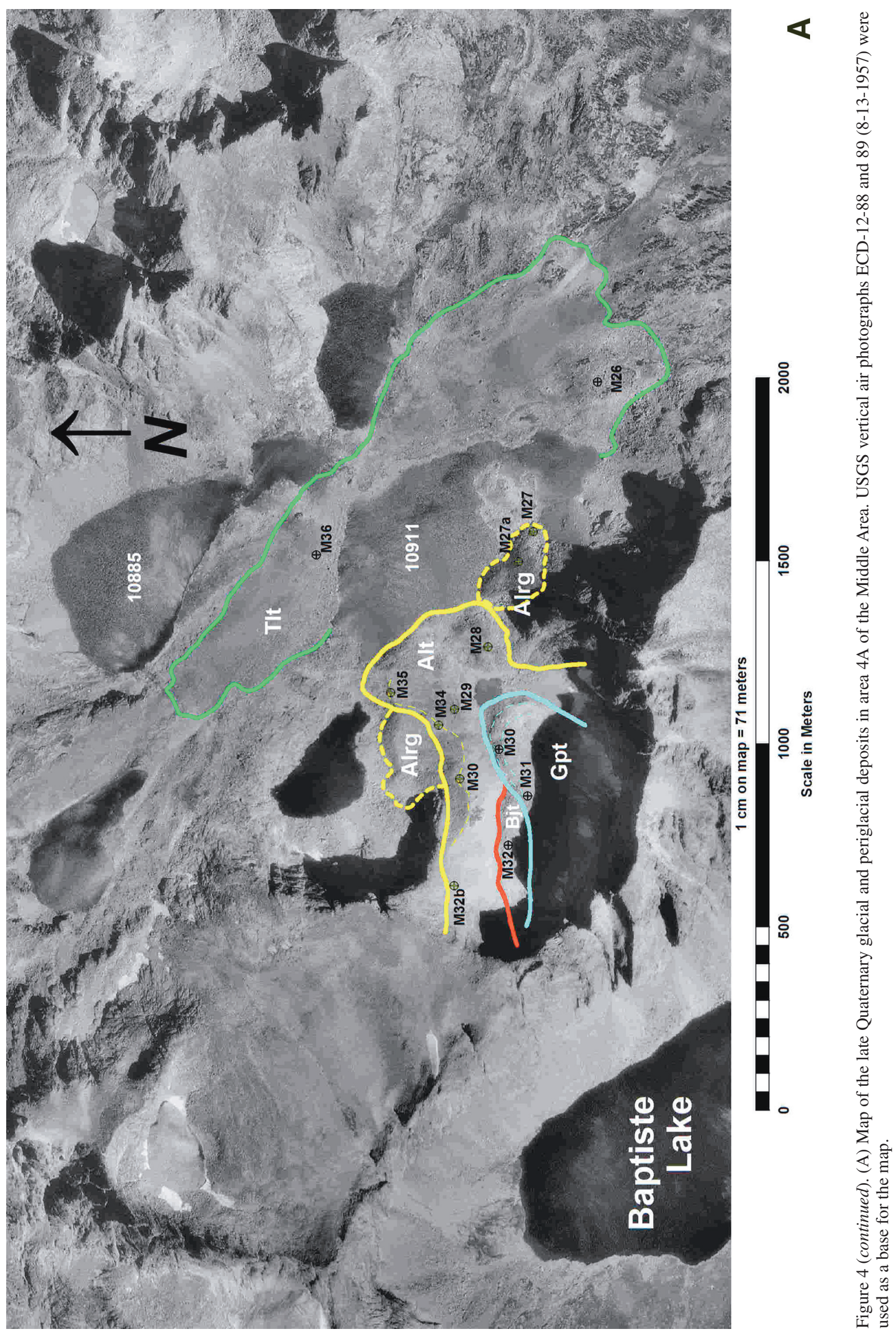




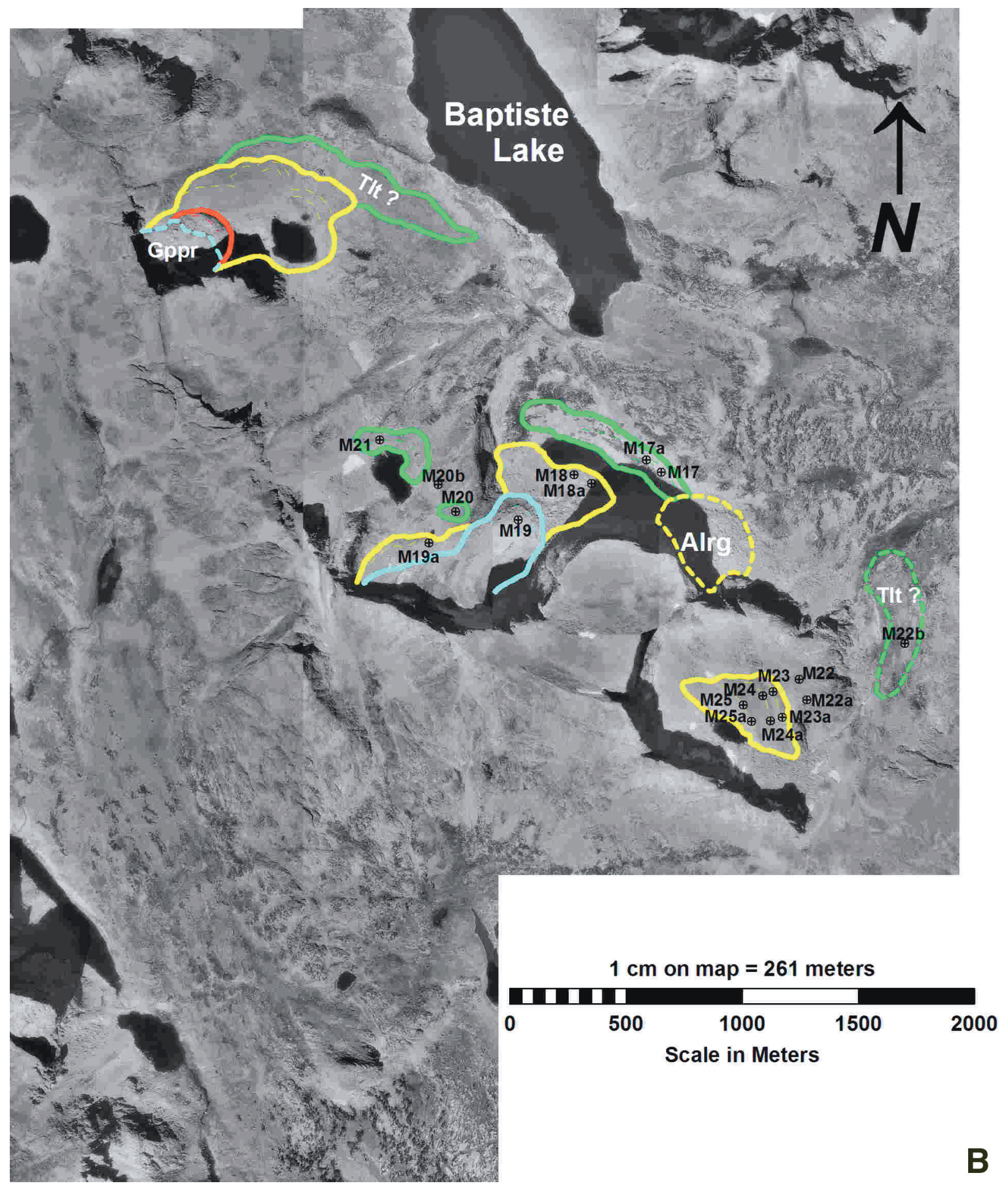

Figure 4 (continued). (B) Map of the late Quaternary glacial and periglacial deposits in area 4B of the Middle Area. USGS vertical air photographs ECD-11-88 and 89 (8-3-1957) were used as a base for the map. 



Figure 4 (continued). (C) Map of the late Quaternary glacial and periglacial deposits in area 4C of the Middle Area. USGS vertical air photographs ECD-12-86 and 87 (8-13-1957) were used as a base for the map. 
14

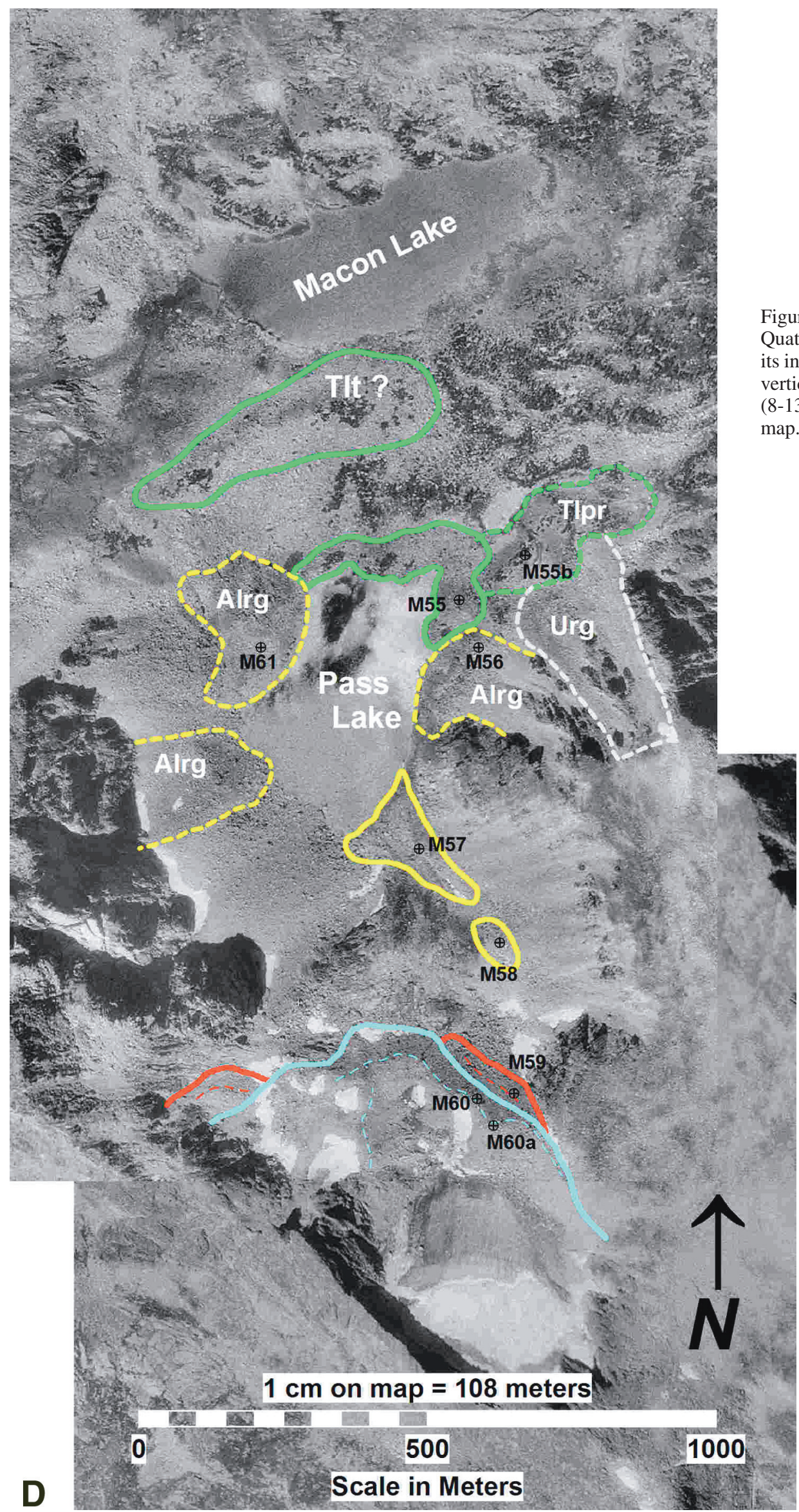

Figure 4 (continued). (D) Map of the late Quaternary glacial and periglacial deposs in area 4D of the Middle Area. USGS vertical air photograph ECD-12-85 8-13-1957) was used as a base for the map. 




Figure 4 (continued). (E) Map of the late Quaternary glacial and periglacial deposits in area 4E of the Middle Area. USGS vertical air photographs ECD-11-100 and 101 (8-3-1957) were used as a base for the map. 


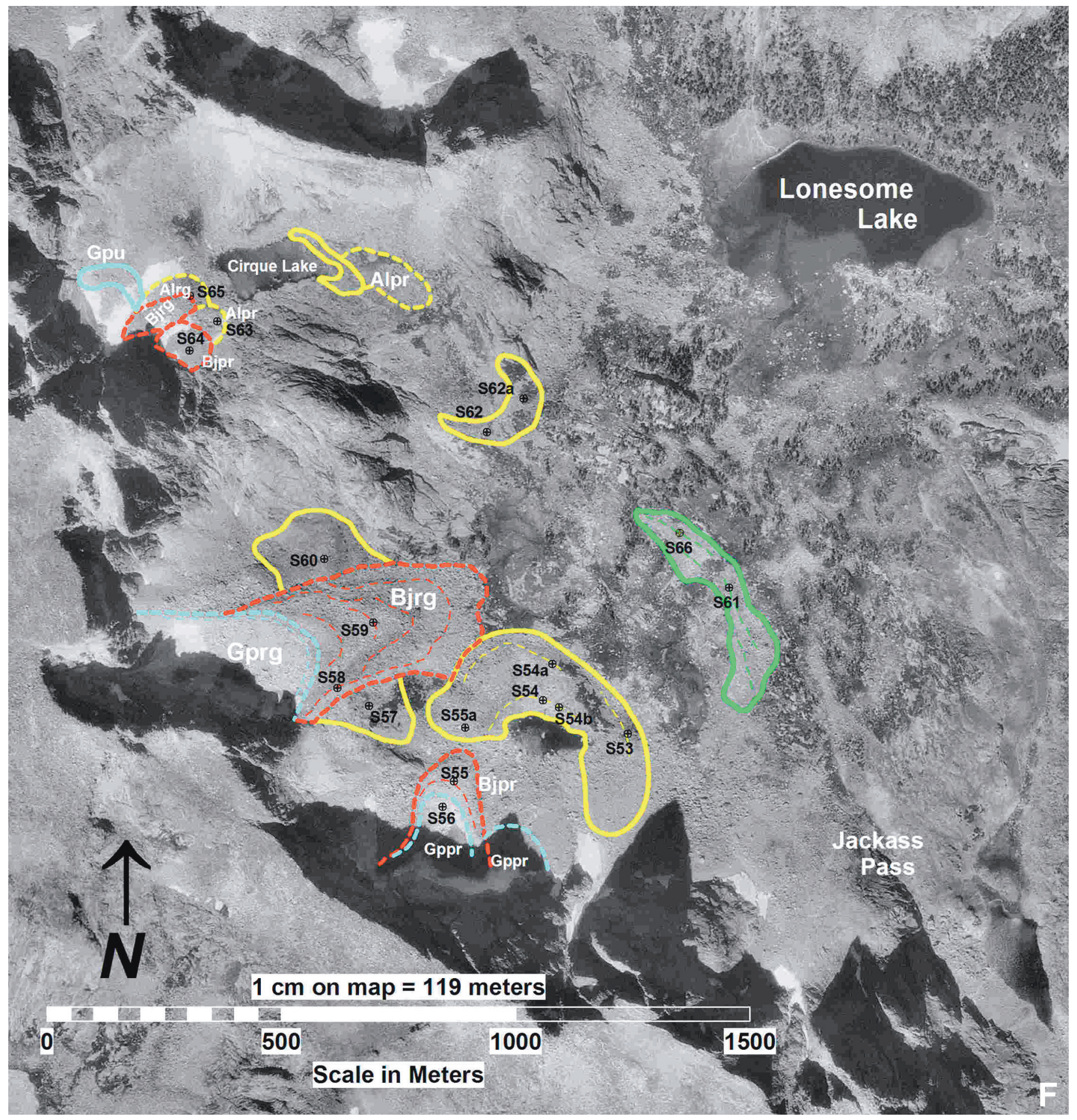

Figure 4 (continued). (F) Map of the late Quaternary glacial and periglacial deposits in area 4F of the Middle Area. USGS vertical air photographs DZT-13-160 and 161 (9-22-1955) were used as a base for the map. 


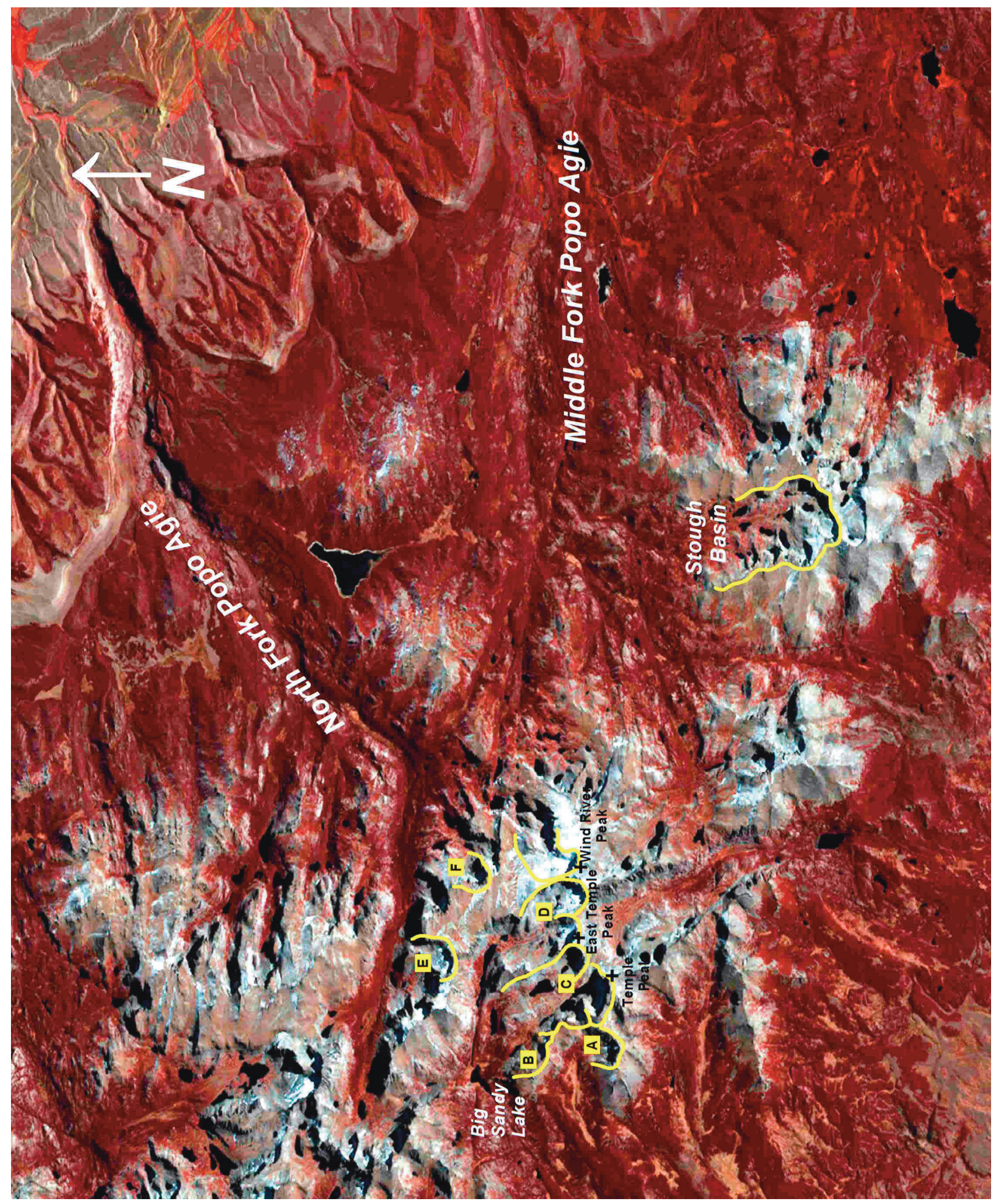

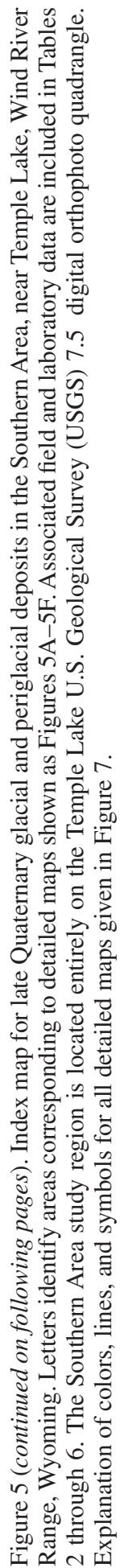






Figure 5 (continued). (A) Map of the late Quaternary glacial and periglacial deposits in area 5A of the Southern Area. USGS vertical air photograph DZT-18-182 (9-22-1955) was used as a base for the map. 


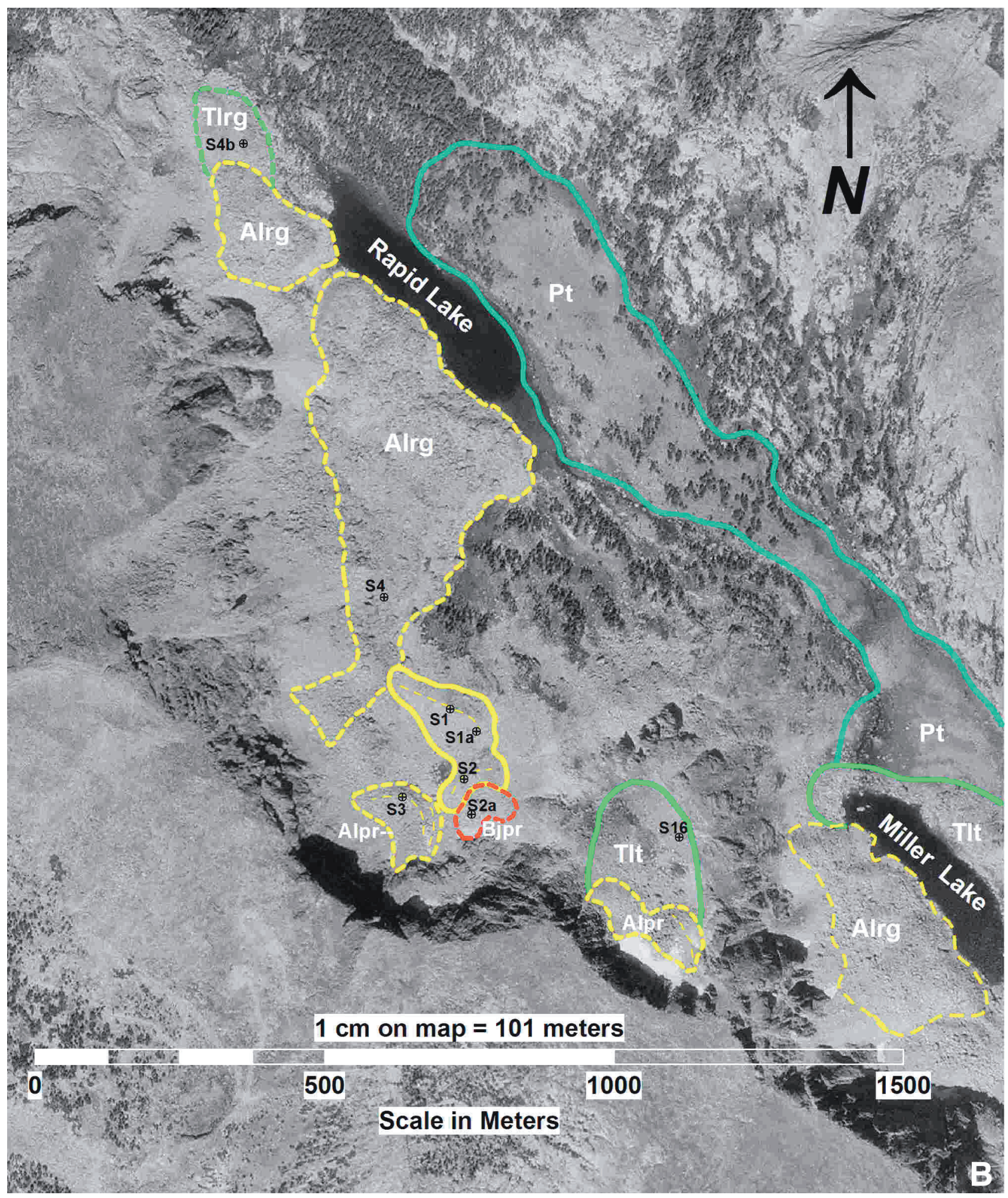

Figure 5 (continued). (B) Map of the late Quaternary glacial and periglacial deposits in area 5B of the Southern Area. USGS vertical air photograph DZT-18-184 (9-22-1955) was used as a base for the map. 


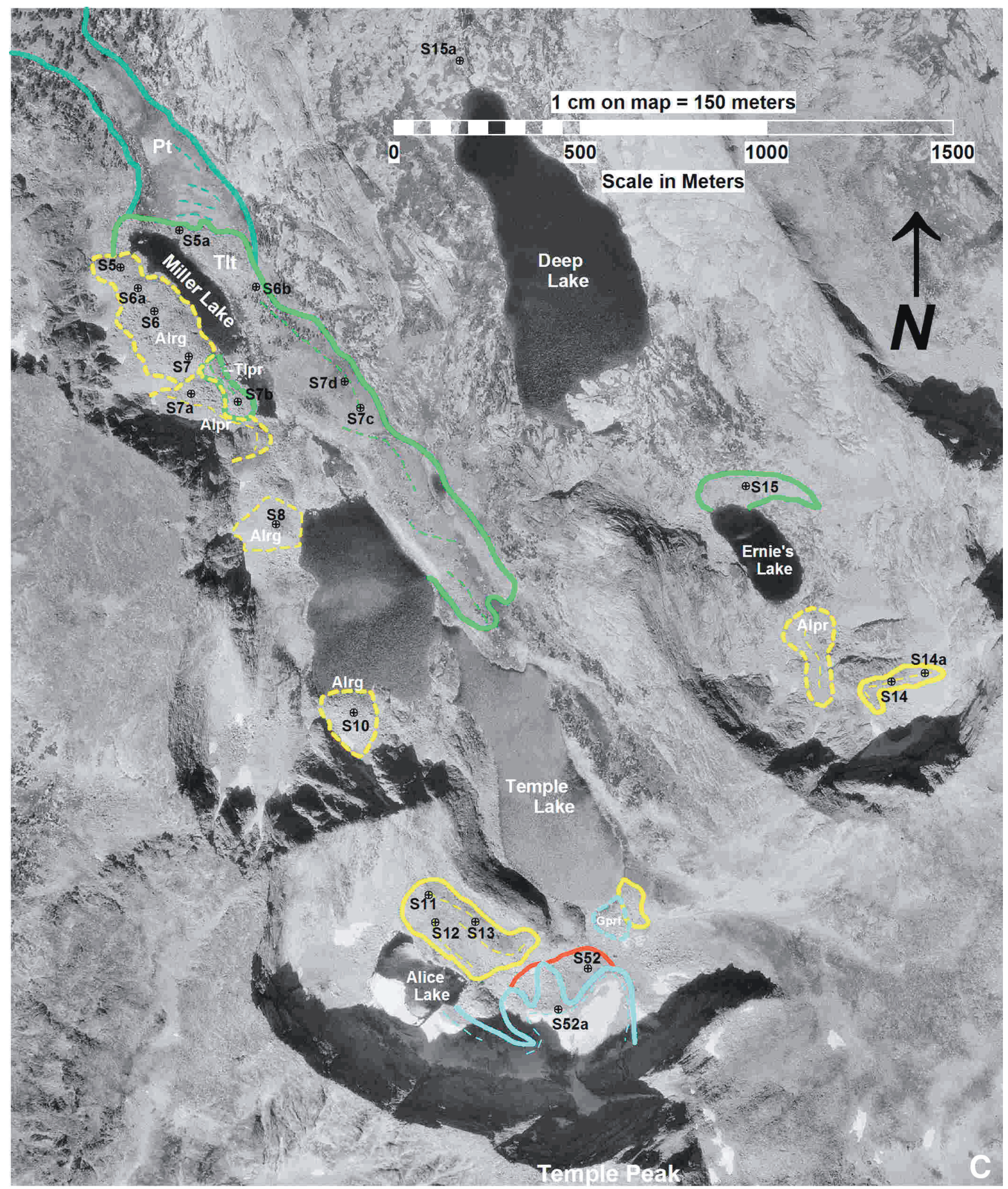

Figure 5 (continued). (C) Map of the late Quaternary glacial and periglacial deposits in area 5C of the Southern Area. USGS vertical air photographs DZT-23-21 and 22 (10-14-1955) were used as a base for the map. 

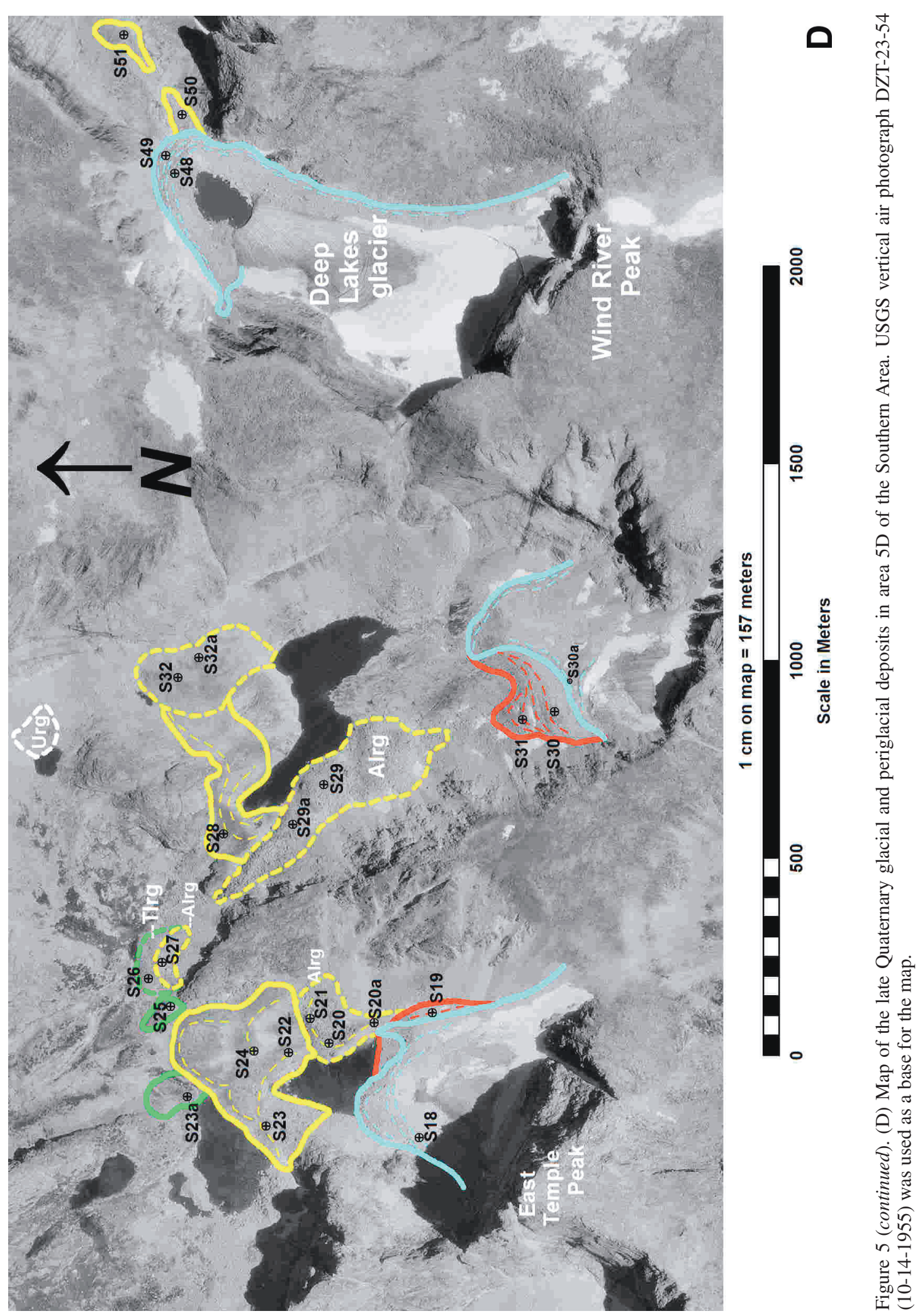




Figure 5 (continued). (E) Map of the late Quaternary glacial and periglacial deposits in area 5E of the Southern Area. USGS vertical air photograph DZT-23-25 (10-14-1955) was used as a base for the map. 

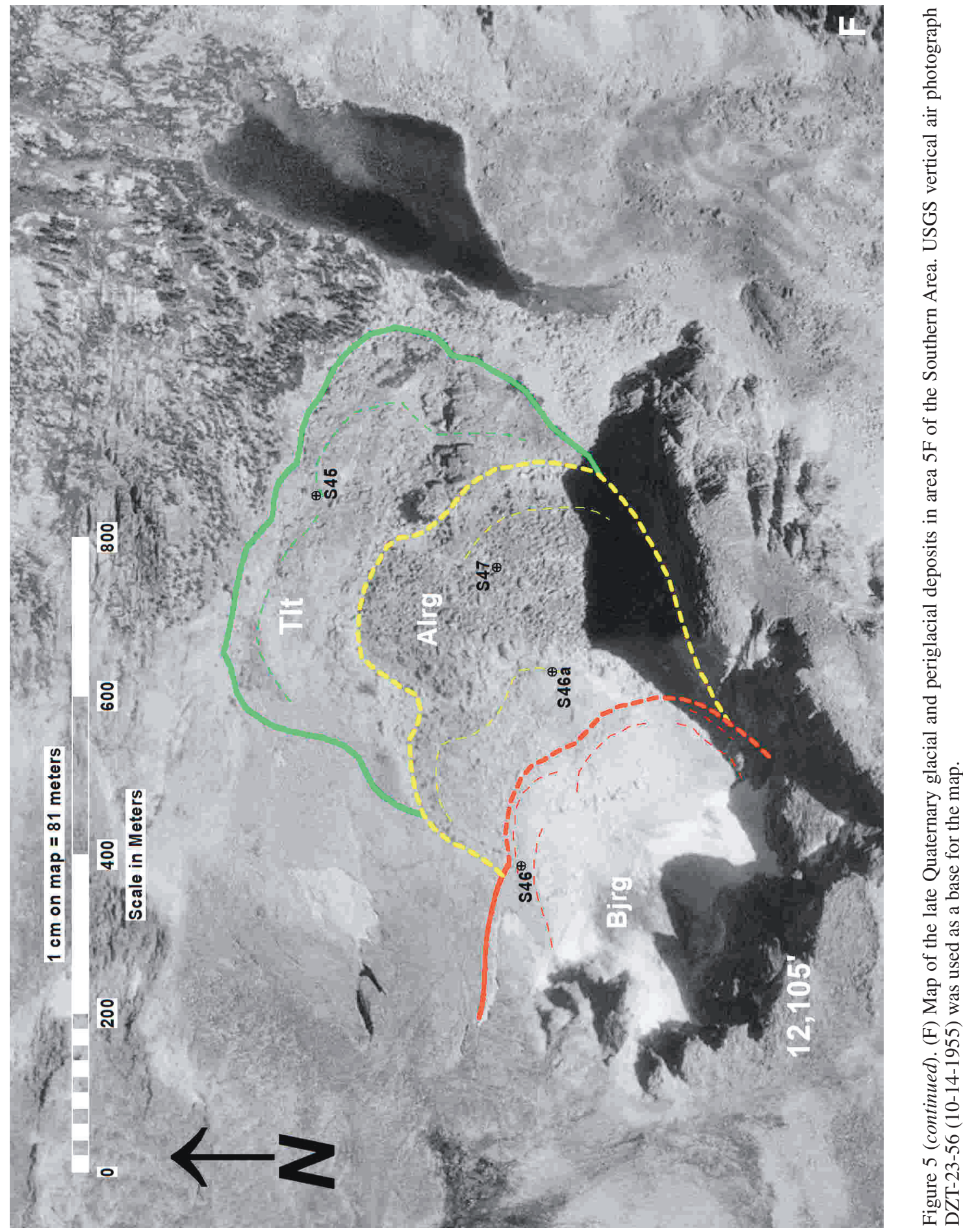


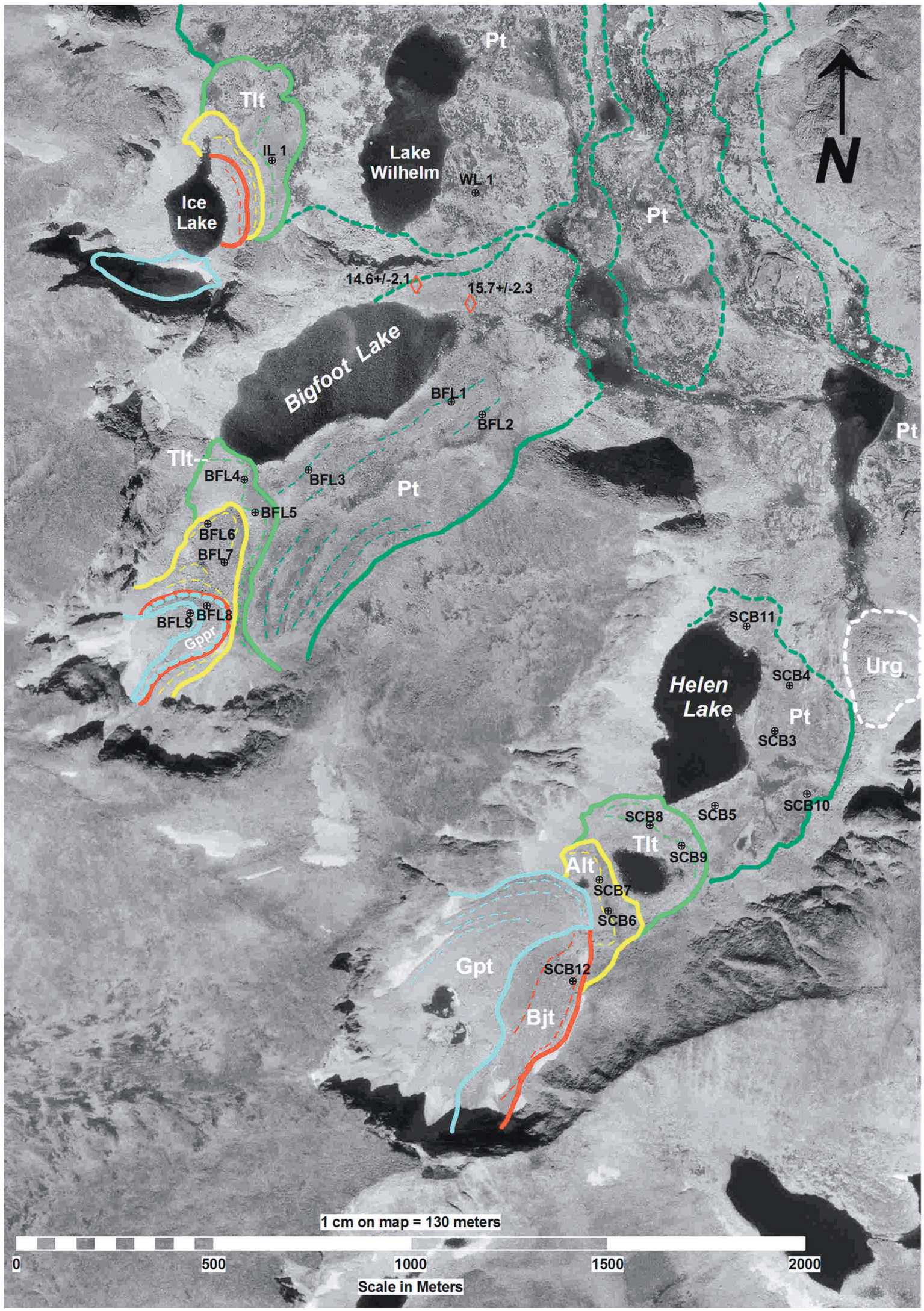

Figure 6. Map of the late Quaternary glacial and periglacial deposits in the southern region of Stough Creek Basin, in the southern Wind River Range, Wyoming. The image is a portion of the SE quadrant of the Sweetwater Gap U.S. Geological Survey orthophoto quadrangle. Explanation of colors, lines, and symbols for all detailed maps given in Figure 7 . The ${ }^{10} \mathrm{Be}$ ages shown NE of Bigfoot Lake are given as k.y. 


\section{Correlation of Allostratigraphic Units}

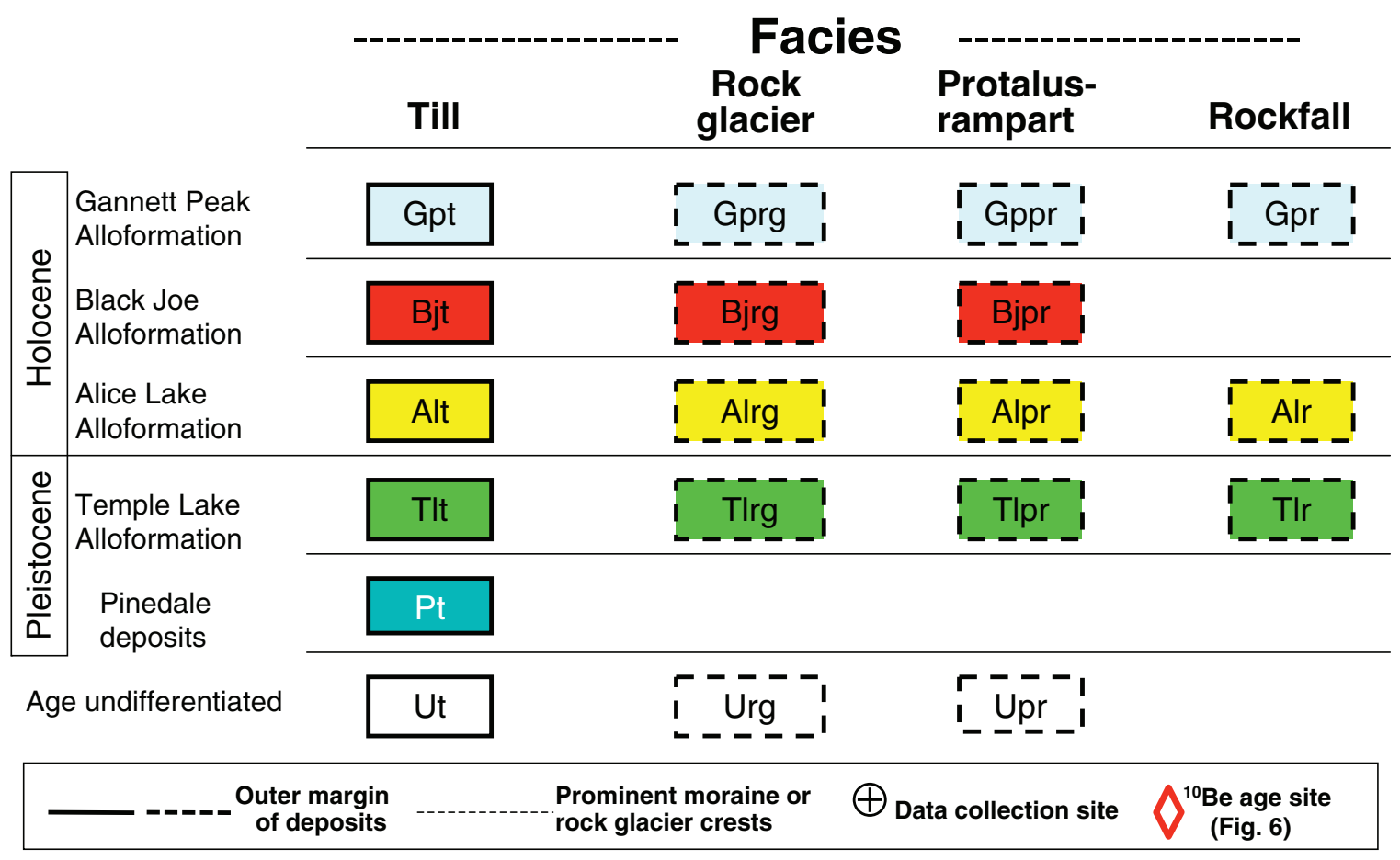

Figure 7. Key to mapped allostratigraphic units (Figs. 3, 4A-4F, 5A-5F, 6) in the three study areas of the Wind River Range. For visual clarity, only the till units are mapped with solid lines.

al. (1995), Gosse et al. (1995a, 1995b, 1999), Miller and Birkeland (1974), Mahaney (1978, 1984a, 1984b, 1987, 1988), Burke and Birkeland (1983), Mahaney et al., (1984a, 1984b), Mahaney and Halvorson (1986), Zielinski (1989), and Zielinski and Davis (1987, 1988). Most of the above studies took place before the development of cosmogenic dating techniques. The advantage of the RA methods is that they can be used in the field while mapping. RA methods can also be used to identify suitable sites for subsequent cosmogenic dating.

\section{Lichen Parameters}

Too few numerical ages are yet available from the Wind River Range from which to construct a detailed growth-rate curve for the range similar to that constructed by Benedict for the Front Range of Colorado (1967, 1968, 1973, 1981, 1985). The first lichen data for the Wind River Range was published by Miller and Birkeland (1974) for the Temple Lake valley in the southern part of the range. Mahaney (1987) constructed the first lichen growth curve for the Wind River Range from Stroud Basin $(\sim 3 \mathrm{~km}$ east of Titcomb Basin) in the northern range based on a single ${ }^{14} \mathrm{C}$ age. Mahaney's reported growth rate $(3.0 \mathrm{~mm} / 100 \mathrm{yr})$ for the linear portion of the lichen growth curve (above the great growth period of the initial $100 \mathrm{yr}$ ) for Rhizocarpon geographicum, sensu lato is lower than Benedict's (1985) growth rate $(3.3 \mathrm{~mm} / 100 \mathrm{yr})$ for the Colorado Front Range. Benedict's curves for the Colorado Front
Range (1967, 1968, 1985) and Mahaney's curve for Stroud Basin were both constructed using the largest maximum thalli diameter. Mahaney's curve was based on a single radiocarbon age of $2760+110$ yr B.P. (Gak-9597) from "a pocket of detrital plant material" found in/on "an outwash deposit (STR21)"..."between an outer and inner end moraine of Indian Basin age" (Mahaney, 1987). Thus, the relation between the deposition of the outwash and that of either moraine is uncertain.

Dahms (2002) developed a growth curve for $R$. geographicum, s.l. on moraine boulders in Stough Creek Basin of $\sim 2.2 \mathrm{~mm} / 100 \mathrm{yr}$ using different parameters (average of the five largest minimum thalli diameters) based only on the inferred ages of the deposits in the basin (Fig. 6 of this report). Using the lichen diameters of $R$. geographicum, s.l. that we present in Tables 4, 5, and 6 of this report (e.g., all studied valleys), Dahms (2002, figure 6 therein) also calculated a growth-rate curve for the greater Wind River Range. The growth rate represented by this "all Wind River Range" curve is $2.4 \mathrm{~mm} / 100 \mathrm{yr}$, close to the growth rate calculated for Stough Creek Basin. Dahms' two growth rates (2002) are based on our minimum limiting ${ }^{14} \mathrm{C}$ age of $3895 \pm 190{ }^{14} \mathrm{C}$ yr B.P. (GX 3242) on organics in a bog on Alice Lake till below the Dinwoody Glacier (site N10b, Fig. 3).

We originally assumed that growth rates might differ from north-to-south in the Wind River Range because climatic conditions in the north appear to relate more to those of the Yellowstone region than to those in the south (located between the 
semi-desert Green River and Wind River basins). Until additional numeric ages can be obtained from our map units, however, we must emphasize that our growth rates are based only on the presently inferred ages of the deposits mapped in this report. The volume of lichen size-data presented in this report, however, when combined with future numeric ages on these deposits, eventually should allow a more well-constrained growth curve to be developed for the Wind River Range.

The lichen species used in this study and the methods of data collection are similar to those of other workers (Benedict, 1967; Locke et al., 1980). We measured the diameters of the largest nearly-circular $R$. geographicum, s.l., Lecanora thomsonii, Lecidea atrobrunnea, and Lecanora aspicilia thalli; for each non-circular thallus, the smaller thallus diameter was measured to avoid the possibility of measuring two intergrown thalli. In contrast, other workers (e.g., Benedict and Mahaney) measured the maximum thallus diameter. (One should keep this in mind when comparing data of various workers.) Most of the lichens were readily identified, but we are not certain that all lichens reported as $R$. geographicum are indeed that species (see Benedict, 1967). Field identification is difficult and laboratory study is usually necessary for correct identification (Benedict, 1967, 1988). For this reason, Rodbell (1992) suggested the term Rhizocarpon subspecies Geographicum. We use the term R. geographicum in the broad sense, for the yellow-green Rhizocarpon species (here termed $R$. geographicum, s.1.).

Each site for which lichen measurements are reported represents the results of a search for large thalli that commonly lasted $\sim 30$ min or more. In addition to size, the maximum percent lichen cover on boulders and the average percent lichen cover on boulders were visually estimated at most sites (Tables 4-6).

\section{Boulder-Weathering Features}

We measured a variety of time-dependent rock-weathering parameters at each site (Tables 4-6). Included in our present data are those previously published by Miller and Birkeland (1974). Mahaney (1978, 1984a, 1984b) and Mahaney et al. (1984b) has published boulder-weathering data for the northern part of the Wind River Range. Currey (1974) published similar data from the Temple Lake valley. Descriptions follow for the various weathering features that we collected.

A. Oxidation of exposed boulder surfaces. As weathering proceeds, the surfaces of clasts become oxidized. Three classes are recognized in this study; unoxidized, slightly oxidized, and oxidized. The latter two classes are distinguished on the basis of intensity and uniformity of oxidation; if oxidation is quite patchy, the boulder is classified as slightly oxidized.

B. Phenocryst relief. K-feldspar phenocrysts locally project above the surface of boulders owing to differential weathering and sloughing off of adjacent minerals. The height of the phenocrysts above the adjacent rock surface was measured.

C. Boulder weathering. Weathered boulders are here defined as those on which at least 25 percent of the exposed surface has minerals that stand in relief. The amount of relief is approximately one-half the diameter of the average mineral. Thus, surfaces of boulders are relatively rough to the touch, whereas fresh ones are relatively smooth. Boulders were classified as either weathered or fresh. According to this definition, boulder surfaces may have lost material by weathering (e.g., spalling) and still be identified as fresh. Degree of weathering was determined on 50-100 boulders at each site.

D. Boulder pitting. Pitted boulders are here defined as boulders on which weathering, presumably by grain-by-grain disintegration, has created a closed depression or circular "pit" on boulder surfaces. Pits with planar sides that seem to result from spalling were not measured. Measurements of weathered boulders are separate from measurements of pitted ones, because all combinations of weathering and pitting are possible; just because a boulder is classed as weathered does not mean that it also is pitted, and vice versa. Pit depths can give an indication of the minimum amount of material removed from boulder surfaces. Pit depth was measured from the average boulder surface to the base of the pit. For most deposits, the range of maximum pit depths on many boulders was recorded. About 50-100 boulders were examined at each site.

$\boldsymbol{E}$. Weathering rinds. As rocks weather, the outermost part becomes discolored to produce an oxidized weathering rind. Such rinds were measured on various rock types from the rock surface to the innermost part of the rind. Rinds were not always present on boulders in our study areas. We believe that this is due to several factors: (1) the relative youthfulness of many of the deposits, (2) the coarse grain size of the granitic rock, and (3) diabase, the best rock for rind studies, was not present at many of the sites. Hence, sampling was not systematic enough for rind data to be of much use for age assignment.

\section{Loess Mantle}

Loess in Rocky Mountain alpine areas is recognized by its grain size, which consists of high proportions of silt and clay and species of heavy minerals different than those in the underlying deposit (Boulding and Boulding, 1981; Dahms, 1991, 1993). Loess is recognized in the field as a non-gritty loam or silt loam which contrasts markedly with the underlying gritty sandy loam or loamy sand matrix of underlying coarser-grained deposits. Typically, loess has been mixed somewhat with the underlying deposit. In this study, loess generally makes up parent material of the upper parts of the soils on older deposits and its maximum thickness is measured, usually at soil sites (Tables 3-5). Loess thickness is measured because it is locally helpful for discriminating between middle Holocene and latest Pleistocene deposits (Birkeland, 1973).

\section{Degree of Soil Development}

A number of soil profiles were examined in hand-dug pits within each mapped area (Tables 2, 3). Various soil parameters 
TABLE 2. LABORATORY DATA FOR SELECTED SOILS, WIND RIVER RANGE, WYOMING

\begin{tabular}{|c|c|c|c|c|c|c|c|c|}
\hline \multirow[b]{2}{*}{ Locality } & \multirow[b]{2}{*}{ Age and facies } & \multirow[b]{2}{*}{ Horizon } & \multirow{2}{*}{$\begin{array}{l}\text { Depth } \\
\text { (cm) }\end{array}$} & \multirow{2}{*}{$\begin{array}{l}\text { Color } \\
\text { (d) }\end{array}$} & \multicolumn{3}{|c|}{ Particle-size distribution* $(<2 \mathrm{~mm})$} & \multirow[b]{2}{*}{$\mathrm{pH}^{\star *}$} \\
\hline & & & & & Sand (2-0.05) & Silt (0.05-0.002) & Clay $(<0.002)$ & \\
\hline \multicolumn{9}{|c|}{ Dinwoody Glacier (Fig. 3) } \\
\hline N9 & Gpt & $\mathrm{Cu}$ & $0-17+$ & $10 Y 6.5 / 1$ & 69.4 & 22.8 & 7.8 & 7.7 \\
\hline \multirow[t]{4}{*}{$\mathrm{N} 10 \mathrm{a}$} & Alt & $A$ & $0-7$ & 10YR 2/2 & 40.3 & 38.6 & 21.1 & 5 \\
\hline & & $2 B w$ & $7-17$ & 10YR $3 / 3$ & 72.7 & 20.4 & 6.9 & 5.3 \\
\hline & & $2 \mathrm{Cox} 1$ & $17-43$ & 10YR 6/3.5 & 70.2 & 25.4 & 4.4 & 5.3 \\
\hline & & $2 \operatorname{Cox} 2$ & $43-72+$ & 10YR 6/3.5 & 82.5 & 13.7 & 3.8 & 5 \\
\hline \multirow[t]{5}{*}{ N16 } & TIt & A & $0-2$ & 10YR 4/2 & 64.6 & 22.9 & 12.5 & 5.7 \\
\hline & & $\mathrm{Bt}$ & $2-18$ & $7.5 Y R 5 / 4$ & 31.5 & 42.7 & 25.8 & 5.9 \\
\hline & & $2 \operatorname{Cox} 1$ & $18-26$ & 10YR 6/4 & 79 & 13.8 & 7.2 & 5 \\
\hline & & $2 \mathrm{Cox} 2$ & $26-146$ & $5 Y 7 / 2$ & 76.4 & 19.3 & 4.3 & 5.1 \\
\hline & & $2 \mathrm{Cu}$ & $146+$ & $5 Y 7 / 2$ & 71.8 & 22.9 & 5.3 & 5.3 \\
\hline \multirow[t]{5}{*}{ N17 } & TIt & A & $0-3$ & 10YR 3.5/2 & 22.3 & 52.2 & 25.5 & 4 \\
\hline & & $\mathrm{Bw}$ & $3-17$ & 7.5YR 5/4 & 25.1 & 48.9 & 26 & 4.3 \\
\hline & & $2 \mathrm{Bt}$ & $17-32$ & 10YR 6/4 & 61.8 & 27.1 & 11.1 & 4.3 \\
\hline & & $2 \operatorname{Cox} 1$ & $32-72$ & 10YR 6/3.5 & 72.3 & 19.8 & 7.9 & 4.3 \\
\hline & & $2 \operatorname{Cox} 2$ & $72-79+$ & $2.5 Y 6 / 3$ & 79.2 & 15.5 & 5.3 & 4.4 \\
\hline \multicolumn{9}{|c|}{ Gannett Glacier (Fig. 3) } \\
\hline \multirow[t]{2}{*}{ N1 } & Gpt & Cox & $0-6$ & $5 Y 7 / 2$ & 83.2 & 13.2 & 3.6 & 5.6 \\
\hline & & $\mathrm{Cu}$ & $6-25+$ & $5 Y 7 / 1$ & 81.4 & 13.8 & 4.8 & 5.8 \\
\hline \multirow[t]{2}{*}{ N4 } & Bjt & Cox & $0-14$ & $5 Y 7 / 2$ & 73.6 & 20.4 & 6 & 5.5 \\
\hline & & $\mathrm{Cu}$ & 14-39+ & $5 Y 7 / 1$ & 77.2 & 17.1 & 5.7 & 6 \\
\hline \multirow[t]{4}{*}{ N5 } & Alt & $A$ & $0-11$ & 10YR 3/2 & 41.7 & 36.6 & 21.7 & 4.8 \\
\hline & & $2 \operatorname{Cox} 1$ & $11-19$ & 10YR 5/3 & 62.9 & 30.1 & 7 & 4.9 \\
\hline & & 2Cox2 & $19-49$ & 10YR 6/3 & 66.3 & 27.7 & 6 & 4.8 \\
\hline & & $2 \mathrm{Cox} 3$ & $49-55+$ & $2.5 Y 7 / 3$ & 75.9 & 17.8 & 6.3 & 4.6 \\
\hline N8 & TIt & $A$ & $0-4$ & 10YR 4/2 & 48.5 & 34 & 17.5 & 5 \\
\hline & & Cox & $4-25$ & 10YR 5/3 & 41.3 & 37.2 & 21.5 & 4.5 \\
\hline & & $A b$ & $25-27$ & 10YR 4/2 & 44.2 & 33.9 & 21.9 & 4.5 \\
\hline & & $2 B t b$ & $27-38$ & 10YR $5 / 4$ & 67.2 & 21 & 11.8 & 4.4 \\
\hline & & $2 \mathrm{Cox} 1 \mathrm{~b}$ & $38-52$ & 10YR 6/4 & 76.5 & 18.2 & 5.3 & 4.6 \\
\hline & & $2 \mathrm{Cox} 2 \mathrm{~b}$ & $52-76+$ & $2.5 Y 7 / 3$ & 77.9 & 18.2 & 3.9 & 4.7 \\
\hline SE of Mc & (Fig. 4B) & & & & & & & \\
\hline M25a & $\overline{\text { Alt }}$ & $\mathrm{Bt} ?$ & $0-14$ & 10YR 4/3 & 58.2 & 32.6 & 9.2 & 5.3 \\
\hline & & $2 \mathrm{Cu}$ & 14-20+ & $2.5 Y 6 / 1$ & 79.4 & 16.8 & 3.8 & 5.9 \\
\hline M23a & Alt & $A$ & $0-3$ & 10YR 5/2 & 68.9 & 21.6 & 9.5 & 5.5 \\
\hline & & $2 \mathrm{Bt}$ & $3-14$ & 10YR 5/3 & 52.5 & 35.1 & 12.4 & 5.8 \\
\hline & & $2 \operatorname{Cox} 1$ & $14-25$ & 10YR $7 / 3$ & 88.8 & 6.7 & 4.5 & 6.4 \\
\hline & & 2Cox2 & 25-28+ & 10YR 6/3 & 82.7 & 12.2 & 5.1 & 6.3 \\
\hline M22a & TIt & A & $0-7$ & 10YR 5/3 & 55.7 & 31.7 & 12.6 & 5.2 \\
\hline & & $\mathrm{Bt}$ & $7-24$ & 10YR 5/4 & 43.7 & 40 & 16.3 & 5.5 \\
\hline & & $2 B w$ & $24-43$ & 10YR $5 / 3$ & 72.2 & 18.9 & 8.9 & 5.4 \\
\hline & & 2Cox & $43-52+$ & 10YR 5/3 & 80.6 & 13.3 & 6.1 & 5.5 \\
\hline S of Gra & ig. $4 \mathrm{C})$ & & & & & & & \\
\hline$\overline{\mathrm{M} 2 \mathrm{a}}$ & Bjt & Cox & $0-7$ & $5 Y 5 / 2$ & 82.2 & 13.3 & 4.5 & 5.6 \\
\hline & & $\mathrm{Cu}$ & $7-22+$ & $5 Y 7 / 2$ & 76.3 & 18.9 & 4.8 & 6.1 \\
\hline M1 & Alt & A & $0-3$ & 10YR 3.5/2 & 35.3 & 44.6 & 20.1 & 5.1 \\
\hline & & $2 \operatorname{Cox} 1$ & $3-40$ & 10YR 5/3 & 77.5 & 16.7 & 5.8 & 5.1 \\
\hline & & $2 \operatorname{Cox} 2$ & $40-50+$ & $2.5 Y 7 / 2$ & 82.6 & 13.6 & 3.8 & 5.4 \\
\hline M12 & Tlt & Bw & $5-10$ & 10YR 4/4 & 74.5 & 19.5 & 6 & 5.3 \\
\hline M16 & Tlt or Pt & $A$ & $0-4$ & 10YR 2/3 & 43.5 & 36.2 & 20.3 & 5.2 \\
\hline & & $\mathrm{Bw}$ & $4-12$ & 7.5YR 4.5/4 & 54.4 & 28.9 & 16.7 & 4.8 \\
\hline & & $2 \mathrm{Bt}$ & $12-32$ & 7.5YR 6/6 & 74.1 & 14.9 & 11 & 4.8 \\
\hline & & $2 \operatorname{Cox} 1$ & $32-46$ & $2.5 Y 5.5 / 4$ & 73.6 & 20.6 & 5.8 & 4.8 \\
\hline & & $2 \operatorname{Cox} 2$ & $46-70+$ & $2.5 Y 6 / 4$ & 69.2 & 24.7 & 6.1 & 4.8 \\
\hline East of $\mathrm{N}$ & hakie (Fig. 4F) & & & & & & & \\
\hline M59 & Bjt & Cox & $0-5$ & $2.5 Y 6 / 2.5$ & 77.7 & 16.8 & 5.5 & 5.5 \\
\hline & & $\mathrm{Cu}$ & $5-22+$ & $2.5 Y 6 / 1$ & 80.3 & 13.8 & 5.9 & 5.8 \\
\hline
\end{tabular}


TABLE 2. LABORATORY DATA FOR SELECTED SOILS, WIND RIVER RANGE, WYOMING (Continued)

\begin{tabular}{|c|c|c|c|c|c|c|c|c|}
\hline \multirow[b]{2}{*}{ Locality } & \multirow[b]{2}{*}{ Age and facies } & \multirow[b]{2}{*}{ Horizon } & \multirow{2}{*}{$\begin{array}{c}\text { Depth } \\
\text { (cm) }\end{array}$} & \multirow{2}{*}{$\begin{array}{l}\text { Color } \\
\text { (d) }\end{array}$} & \multicolumn{3}{|c|}{ Particle-size distribution* $(<2 \mathrm{~mm})$} & \multirow[b]{2}{*}{$\mathrm{pH}^{* *}$} \\
\hline & & & & & Sand $(2-0.05)$ & Silt (0.05-0.002) & Clay $(<0.002)$ & \\
\hline \multicolumn{9}{|c|}{ South Fork Lakes (Fig. 4E) } \\
\hline \multirow[t]{3}{*}{$\overline{\mathrm{M} 42}$} & Bjt & Cox & $0-6$ & $2.5 Y 4.5 / 2$ & 66.5 & 25.5 & 8 & 5.5 \\
\hline & & $2 \operatorname{Cox}$ & $6-15$ & $2.5 Y 5 / 2$ & 86.9 & 8 & 5.1 & 5.7 \\
\hline & & $2 \mathrm{Cu}$ & $15-25+$ & $2.5 Y 5 / 1$ & 91.4 & 5.2 & 3.4 & 5.8 \\
\hline \multirow[t]{3}{*}{ M44 } & Alt & Bw & $0-10$ & 10YR $4.5 / 3$ & 76.3 & 18 & 5.7 & 5.8 \\
\hline & & Cox1 & $10-30$ & 10YR 6/3 & 84.2 & 11.4 & 4.4 & 6 \\
\hline & & Cox2 & $30-38+$ & 10YR $7 / 2$ & 86.7 & 9.7 & 3.6 & 6.2 \\
\hline \multirow[t]{4}{*}{ M47 } & Alt & A & $0-2$ & 10YR 2/3 & 39.7 & 41.7 & 18.6 & 5.8 \\
\hline & & $\mathrm{Bw}$ & $2-9$ & 10YR $3 / 3$ & 55.7 & 30.1 & 14.2 & 5.4 \\
\hline & & 2Cox1 & $9-27$ & 10YR 6/4 & 86.1 & 10 & 3.9 & 5.4 \\
\hline & & 2Cox2 & $27-50+$ & 10YR 7/3 & 90.3 & 6.9 & 2.8 & 5.5 \\
\hline \multirow[t]{4}{*}{ M48b } & Alt & A & 0-4 & 10YR $3 / 3$ & 45.7 & 36.5 & 17.8 & 6.2 \\
\hline & & $2 \mathrm{Bt}$ & $4-15$ & 10YR 4/4 & 66.8 & 23.9 & 9.8 & 6 \\
\hline & & $2 \operatorname{Cox} 1$ & $15-45$ & 10YR 6/4 & 84.9 & 10.6 & 4.5 & 5.8 \\
\hline & & 2Cox2 & $45-55+$ & $5 Y 7 / 3$ & 75.4 & 19.6 & 5 & 5.7 \\
\hline \multirow[t]{4}{*}{ M41 } & Alt & A & $0-16$ & 10YR $3 / 3$ & 39.7 & 39.3 & 21 & 5 \\
\hline & & Bw & $16-29$ & 7.5YR 5/4 & 46.5 & 34.3 & 19.2 & 5.1 \\
\hline & & $2 \operatorname{Cox} 1$ & $29-54$ & 10YR 6/3 & 69.3 & 24.4 & 6.3 & 5.1 \\
\hline & & 2Cox2 & $54-60+$ & $2.5 Y 7 / 3$ & 56.1 & 38.8 & 5.1 & 5 \\
\hline \multirow[t]{5}{*}{ M51a } & TIt & A & $0-5$ & 10YR 4/3 & 48.5 & 35.4 & 16.1 & 5.6 \\
\hline & & $\mathrm{Ej}$ & $5-9$ & 10YR 5/4 & 41.3 & 40.3 & 18.4 & 5.1 \\
\hline & & 2Bw1 & $9-19$ & 10YR 6/7 & 60.5 & 30.1 & 9.4 & 5.2 \\
\hline & & 2Bw2 & 19-35 & 10YR 6/6 & 61.2 & 31.6 & 7.2 & 5.2 \\
\hline & & $2 \mathrm{Cox}$ & $35-46+$ & $2.5 Y 7 / 2.5$ & 61.8 & 29.4 & 8.8 & 5.1 \\
\hline \multicolumn{9}{|c|}{ Cirque of the Towers (Fig. 4F) } \\
\hline S54a & Alt & $A$ & $0-3$ & 10YR 5/4 & 54 & 33.3 & 12.7 & 5.1 \\
\hline & & $\mathrm{Bt}$ & $3-16$ & 10YR 4/5 & 46.4 & 36.2 & 17.4 & 5.2 \\
\hline & & $2 \operatorname{Cox}$ & $16-27+$ & $5 Y 5.5 / 4$ & 76.7 & 17.5 & 5.8 & 5.5 \\
\hline S66 & Tlt & A & $0-3$ & 10YR $3 / 2$ & 25 & 50.2 & 24.8 & 4.6 \\
\hline & & Bw & $3-25$ & 10YR 4/3 & 26.1 & 47.6 & 26.3 & 4.7 \\
\hline & & $2 \operatorname{Cox} 1$ & $25-32$ & 10YR 5.5/4 & 66.2 & 23.2 & 10.6 & 5.1 \\
\hline & & 2Cox2 & $32-43+$ & $2.5 Y 5 / 4$ & 56.7 & 34.8 & 8.5 & 5.3 \\
\hline Temple Lak & & & & & & & & \\
\hline$\overline{\mathrm{S} 11}$ & Alt & $A$ & $0-3$ & 10YR 4/2 & 78.1 & 13.9 & 8 & 5.5 \\
\hline & & $\mathrm{Bt}$ & $3-12$ & 10YR 6/3 & 71.4 & 19.4 & 9.2 & 5.9 \\
\hline & & Cox1 & $12-27$ & 10YR 5/3 & 82.8 & 12.1 & 5.1 & 5.7 \\
\hline & & Cox2 & $27-52$ & $2.5 Y 5 / 3$ & 81.4 & 13.8 & 4.8 & 5.9 \\
\hline & & Cox3 & $52-66+$ & $2.5 Y 5 / 3$ & 85.2 & 10.5 & 4.3 & 5.1 \\
\hline SE of S6a & Alrg & A & $0-2$ & 10YR 3/2 & 56.8 & 28.2 & 15 & 6.2 \\
\hline & & $\mathrm{Bt}$ & $2-8$ & 10YR 3/3.5 & 62.1 & 24.3 & 13.6 & 5.9 \\
\hline & & Cox & $8-34$ & $2.5 Y 4 / 2$ & 80.7 & 15.7 & 3.6 & 5.9 \\
\hline & & $\mathrm{Cu}$ & $34+$ & $5 Y 5 / 2.5$ & 84.2 & 12.5 & 3.3 & 6 \\
\hline S7d & Tlt & A & $0-8$ & 10YR 5/3 & 52.5 & 28.9 & 18.6 & 5.9 \\
\hline & & $\mathrm{Bt}$ & $8-25$ & 10YR 5/3 & 54.4 & 30.6 & 15 & 5.5 \\
\hline & & 2Cox & $25-45$ & $2.5 Y 6 / 3$ & 58.4 & 29.6 & 12 & 4.9 \\
\hline & & $2 \mathrm{Cu}$ & $45-60+$ & $5 Y 6 / 2$ & 61.3 & 27.9 & 10.8 & 5.1 \\
\hline S5a & Tlt & $A$ & 0-4 & 10YR 3/2.5 & 54 & 31 & 15 & 5.9 \\
\hline & & $2 \mathrm{Bt}$ & $4-17$ & 10YR 4/5 & 68.3 & 21.7 & 10.3 & 6 \\
\hline & & 2 Cox & $17-54+$ & 10YR 5/4 & 78 & 15.3 & 6.7 & 5.9 \\
\hline Deep Lake & & & & & & & & \\
\hline$\overline{\mathrm{S} 14 a}$ & Alt & A & $0-4$ & 10YR 4/2.5 & 84.2 & 9.4 & 6.4 & 5.6 \\
\hline & & Bw & $4-12$ & 10YR 4/3 & 81 & 12.6 & 6.4 & 5.4 \\
\hline & & Cox & $12-50+$ & 10YR 6/3 & 80.2 & 14.3 & 5.5 & 5.3 \\
\hline S15 & Tlt & $A$ & $0-5$ & 10YR 3/3 & 29 & 48.5 & 22.5 & 4.9 \\
\hline & & $A$ or $B$ & $5-17$ & 10YR 4/3 & 38.9 & 40.1 & 21 & 4.8 \\
\hline & & $2 \mathrm{Bt}$ & $17-32$ & 7.5YR 5/5 & 56.2 & 27.5 & 16.3 & 4.9 \\
\hline & & 2Cox & $32-52+$ & 10YR 7/4 & 53.2 & 39.7 & 6.5 & 5.1 \\
\hline
\end{tabular}


TABLE 2. LABORATORY DATA FOR SELECTED SOILS, WIND RIVER RANGE, WYOMING (Continued)

\begin{tabular}{|c|c|c|c|c|c|c|c|c|}
\hline \multirow[b]{2}{*}{ Locality } & \multirow[b]{2}{*}{ Age and facies } & \multirow[b]{2}{*}{ Horizon } & \multirow{2}{*}{$\begin{array}{l}\text { Depth } \\
\text { (cm) }\end{array}$} & \multirow{2}{*}{$\begin{array}{l}\text { Color } \\
\text { (d) }\end{array}$} & \multicolumn{3}{|c|}{ Particle-size distribution* $(<2 \mathrm{~mm})$} & \multirow[b]{2}{*}{$\mathrm{pH}^{* *}$} \\
\hline & & & & & Sand $(2-0.05)$ & Silt (0.05-0.002) & Clay $(<0.002)$ & \\
\hline \multicolumn{9}{|c|}{ NE of East Temple Peak (Fig. 5D) } \\
\hline \multirow[t]{3}{*}{ S19 } & Bjt & $A$ & $0-1$ & 10YR 4/2 & 73.6 & 17.6 & 8.8 & 5.2 \\
\hline & & Cox & $1-6$ & $5 Y 6 / 2$ & 77.7 & 17.5 & 4.5 & 6 \\
\hline & & $\mathrm{Cu}$ & $6+$ & $5 Y 7 / 2$ & 85.9 & 10.6 & 3.5 & 6.2 \\
\hline \multirow[t]{4}{*}{ S20a } & Alrg & $A$ & $0-4$ & 10YR 3/3.5 & 66 & 21.9 & 12.1 & 5.9 \\
\hline & & $\mathrm{Bw}$ & $4-11$ & 10YR $3.5 / 3$ & 69.5 & 20.3 & 10.2 & 5.7 \\
\hline & & $2 \operatorname{Cox}$ & $11-19$ & $2.5 Y 6 / 3$ & 79.4 & 15.4 & 5.2 & 5.7 \\
\hline & & $2 \mathrm{Cu}$ & 19-35+ & $5 Y 6 / 2$ & 80.9 & 13.7 & 5.4 & 5.3 \\
\hline \multicolumn{9}{|c|}{ NE of East Temple Peak (Fig. 5D) } \\
\hline \multirow[t]{2}{*}{$\mathrm{S} 24$} & Alt & $\mathrm{Bt}$ & $2-8$ & 10YR 4/3 & 57 & 29.4 & 13.6 & 5.3 \\
\hline & & $\mathrm{Cu}$ & $12-20+$ & $5 Y 7 / 2$ & 63.1 & 30 & 6.9 & 5.5 \\
\hline \multirow[t]{3}{*}{ S23a } & TIt & $A$ & $0-16$ & 10YR 3/2 & 47.1 & 34 & 18.9 & 5 \\
\hline & & $\mathrm{Bt}$ & $16-46$ & 7.5YR $5 / 3$ & 33.2 & 43.5 & 23.3 & 4.7 \\
\hline & & 2 Cox & $46-52+$ & 10YR 6/2 & 68 & 21.5 & 10.5 & 4.7 \\
\hline \multicolumn{9}{|c|}{ West of Wind River Peak (Fig. 5D) } \\
\hline \multirow[t]{4}{*}{ S28 } & Alt & $\mathrm{A} 1$ & $0-7$ & 10YR 3/3 & 23.8 & 48.7 & 27.5 & 5.6 \\
\hline & & A3 & $7-15$ & 10YR $3 / 2$ & 51 & 31.7 & 17.3 & 5.9 \\
\hline & & $2 B w$ & $15-27$ & 10YR $4 / 3$ & 73.9 & 17.9 & 8.2 & 5.7 \\
\hline & & 2 Cox & $27-43+$ & $2.5 Y 3.5 / 5$ & 53.9 & 33.7 & 12.4 & 5.8 \\
\hline North of Wind & r Peak (Fig. 5D) & & & & & & & \\
\hline S48-3rd ridge & Gpt & $A$ & $0-2$ & $2.5 Y 5 / 2$ & 82.5 & 12.3 & 5.2 & 5.9 \\
\hline & & $\mathrm{Cu}$ & $2+$ & $5 Y 7 / 1$ & 61.9 & 26.5 & 11.6 & 6.8 \\
\hline S51 & Alt & $A$ & $0-5$ & 10YR 3/2 & 65.5 & 21.8 & 12.7 & 6.4 \\
\hline & & $2 \mathrm{Bw}$ & $5-18$ & 10YR 4/3 & 76.8 & 15.7 & 7.5 & 6.1 \\
\hline & & 2Cox & 18-35+ & $2.5 Y 6 / 3$ & 80.3 & 13.9 & 5.8 & 6.1 \\
\hline Stough Creek & n (Fig. 6) & & & & & & & \\
\hline$\overline{\text { BFL9 }}$ & $\mathrm{Gpt}$ & Cox & $0-5$ & $2.5 \mathrm{Y} 3 / 2(\mathrm{~m})$ & 83.7 & 11.5 & 4.8 & - \\
\hline & & $2 \mathrm{Cu}$ & $5-25$ & $5 Y 5 / 2$ & 90.4 & 5.9 & 3.7 & - \\
\hline BFL8 & Bjt & Cox & $0-5$ & $2.5 Y 5 / 3$ & 85.0 & 9.1 & 5.9 & - \\
\hline & & $\mathrm{Cu}$ & $5-25$ & $5 Y 5 / 3$ & 86.6 & 9.0 & 4.3 & - \\
\hline SCB12 & Bjt & $A$ & $0-2$ & 10YR 5/2 & 79.9 & 14.6 & 5.5 & - \\
\hline & & Cox & $2-10$ & $5 Y 4 / 3$ & 82.5 & 12.4 & 5.1 & - \\
\hline & & $2 \mathrm{Cu}$ & $10-30+$ & $5 Y 5 / 2$ & 91.8 & 3.6 & 4.6 & - \\
\hline BFL6 & Alt & $A$ & $0-10$ & 10YR 5/2 & 57.0 & 23.9 & 19.1 & - \\
\hline & & $2 \mathrm{Bt}$ & $10-20$ & 10YR $5 / 3$ & 66.7 & 21.2 & 12.1 & - \\
\hline & & $2 \mathrm{Cox} 1$ & $20-28$ & $2.5 Y 5 / 3$ & 68.3 & 21.9 & 9.8 & - \\
\hline & & $2 \mathrm{Cox} 2$ & $28-45+$ & $2.5 Y 6 / 2$ & 74.5 & 16.9 & 8.6 & - \\
\hline BFL7 & Alt & A & $0-7$ & 10YR 5/2 & 63.5 & 24.3 & 12.2 & - \\
\hline & & $2 B w$ & $7-15$ & 10YR 5/3 & 72.5 & 17.8 & 9.7 & - \\
\hline & & $2 \mathrm{Cox} 1$ & $15-30$ & $2.5 Y 5 / 3$ & 73.3 & 17.1 & 9.6 & - \\
\hline & & $2 \mathrm{Cox} 2$ & $30-45+$ & $2.5 Y 6 / 2$ & 70.5 & 19.6 & 9.9 & - \\
\hline SCB6 & Alt & $A$ & $0-5$ & 10YR 3/1 & 39.8 & 41.4 & 18.8 & - \\
\hline & & $\mathrm{Bt}$ & $5-17$ & 10YR 3/2 & 46.2 & 39.3 & 14.4 & - \\
\hline & & $2 \operatorname{Cox} 1$ & $17-30$ & 10YR 6/2 & 64.1 & 27.9 & 8.1 & - \\
\hline & & 2Cox2 & $30-50+$ & $2.5 Y 6 / 2$ & 65.6 & 27.4 & 7.0 & - \\
\hline SCB7 & Alt & A & $0-5$ & 10YR 4/2 & 65.6 & 24.2 & 10.3 & - \\
\hline & & Bw & $5-15$ & 10YR 5/2 & 69.0 & 23.9 & 7.0 & - \\
\hline & & $2 \operatorname{Cox} 1$ & $15-25$ & $2.5 Y 6 / 3$ & 72.7 & 21.5 & 5.8 & - \\
\hline & & $2 \mathrm{Cox} 2$ & $25-50+$ & $2.5 Y 6 / 2$ & 80.1 & 15.3 & 4.6 & - \\
\hline BFL4 & TIt & $\mathrm{OA}$ & $0-5$ & 10YR 5/2 & 71.7 & 17.1 & 11.1 & - \\
\hline & & $\mathrm{Bt}$ & $5-13$ & 10YR 5/3 & 64.4 & 25.0 & 10.6 & - \\
\hline & & $2 \mathrm{Cox} 1$ & $13-37$ & $2.5 Y 6 / 4$ & 74.6 & 18.6 & 6.9 & - \\
\hline & & 2Cox2 & $37-63+$ & $2.5 Y 6 / 2$ & 73.6 & 19.2 & 7.2 & - \\
\hline BFL5 & Tlt & A & 0-9 & 10YR 4/2 & 63.1 & 23.0 & 13.9 & - \\
\hline & & $2 \mathrm{Bt}$ & $9-22$ & 10YR 5/4 & 63.7 & 24.0 & 12.3 & - \\
\hline & & $2 \mathrm{Cox} 1$ & $22-55$ & $2.5 Y 6 / 4$ & 70.2 & 20.0 & 9.8 & - \\
\hline & & $2 \operatorname{Cox} 2$ & $55-75+$ & $2.5 Y 7 / 2$ & 82.9 & 12.0 & 5.1 & - \\
\hline
\end{tabular}


TABLE 2. LABORATORY DATA FOR SELECTED SOILS, WIND RIVER RANGE, WYOMING (Continued)

\begin{tabular}{|c|c|c|c|c|c|c|c|c|}
\hline \multirow[b]{2}{*}{ Locality } & \multirow[b]{2}{*}{ Age and facies } & \multirow[b]{2}{*}{ Horizon } & \multirow{2}{*}{$\begin{array}{l}\text { Depth } \\
(\mathrm{cm})\end{array}$} & \multirow{2}{*}{$\begin{array}{l}\text { Color } \\
\text { (d) }\end{array}$} & \multicolumn{3}{|c|}{ Particle-size distribution $^{\star}(<2 \mathrm{~mm})$} & \multirow[b]{2}{*}{$\mathrm{pH}^{* *}$} \\
\hline & & & & & Sand $(2-0.05)$ & Silt $(0.05-0.002)$ & Clay $(<0.002)$ & \\
\hline \multicolumn{9}{|c|}{ Stough Creek Basin (Fig. 6) } \\
\hline \multirow[t]{4}{*}{ SCB8 } & $\bar{T}$ Tlt & A & $0-7$ & 10YR 4/2 & 49.2 & 35.4 & 15.4 & 一 \\
\hline & & $\mathrm{Bt}$ & $7-15$ & 10YR 4/3 & 55.1 & 32.3 & 12.5 & - \\
\hline & & 2Cox1 & 15-39 & 10YR 4/4 (m) & 84.1 & 14.3 & 1.5 & - \\
\hline & & 2Cox & $39-50+$ & $2.5 Y 6 / 3$ & 83.4 & 16.4 & 0.2 & - \\
\hline \multirow[t]{4}{*}{ SCB9 } & Tlt & A & $0-5$ & 10YR 4/2 & 61.8 & 26.4 & 11.8 & - \\
\hline & & $2 \mathrm{Bt}$ & $5-11$ & 10YR 4/3 & 62.2 & 29.0 & 8.8 & - \\
\hline & & $2 \operatorname{Cox} 1$ & $11-35$ & 10YR 4/4 (m) & 69.3 & 30.3 & 0.4 & - \\
\hline & & 2Cox2 & $35-50+$ & $2.5 Y 6 / 2$ & 80.4 & 19.5 & 0.1 & - \\
\hline \multirow[t]{4}{*}{ IL1 } & Tlt & $A$ & $0-15$ & 10YR 4/2 & 48.1 & 33.0 & 18.9 & - \\
\hline & & $\mathrm{Bt}$ & $15-35$ & 10YR 5/4 & 52.5 & 30.4 & 17.1 & - \\
\hline & & $2 \mathrm{BC}$ & $35-55$ & 10YR 6/4 & 70.3 & 23.2 & 6.5 & - \\
\hline & & 2 Cox & $55+$ & $2.5 Y 7 / 3$ & 72.3 & 19.7 & 8.0 & - \\
\hline \multirow[t]{5}{*}{ BFL1 } & $\mathrm{Pt}$ & $A$ & $0-8$ & 10YR 3/2 & 57.4 & 28.2 & 14.4 & - \\
\hline & & $\mathrm{Bt}$ & $8-18$ & 7.5YR $4 / 3$ & 62.8 & 20.0 & 17.1 & - \\
\hline & & $2 B C$ & $18-27$ & 10YR 7/4 & 80.1 & 16.1 & 3.8 & - \\
\hline & & $2 \operatorname{Cox} 1$ & $27-65$ & $2.5 Y 7 / 4$ & 60.5 & 30.0 & 9.5 & - \\
\hline & & 2Cox 2 & 65-90+ & $2.5 Y 6 / 4$ & 78.1 & 15.8 & 6.1 & - \\
\hline \multirow[t]{5}{*}{ BFL2 } & $\mathrm{Pt}$ & A & 0-5 & 10YR 3/2 & 56.5 & 25.4 & 18.0 & - \\
\hline & & $A B$ & $5-18$ & $7.5 Y R 4 / 3$ & 66.2 & 20.3 & 13.5 & - \\
\hline & & $2 \mathrm{Bt}$ & $18-60$ & 10YR 6/4 & 63.7 & 23.0 & 13.3 & - \\
\hline & & 2Cox1 & $60-80$ & $2.5 Y 6 / 4$ & 75.1 & 17.5 & 7.4 & - \\
\hline & & 3 Cox2 & $80+$ & $2.5 Y 6 / 4$ & 78.1 & 15.8 & 6.1 & - \\
\hline \multirow[t]{5}{*}{ BFL3 } & $\mathrm{Pt}$ & A & $0-12$ & 10YR 4/2 & 65.2 & 19.7 & 15.1 & - \\
\hline & & $A B$ & $12-23$ & $7.5 Y R \quad 4 / 3$ & 63.5 & 21.5 & 15.0 & - \\
\hline & & $\mathrm{Bt}$ & $23-60$ & 10YR 6/4 & 57.7 & 30.9 & 11.4 & - \\
\hline & & 2Cox1 & $60-72$ & $2.5 Y 6 / 4$ & 64.7 & 24.1 & 11.2 & - \\
\hline & & 2Cox2 & $72+$ & $2.5 Y 6 / 4$ & 78.0 & 16.0 & 6.0 & - \\
\hline \multirow[t]{4}{*}{ SCB2 } & $\mathrm{Pt}$ & $A$ & $0-9$ & 10YR 3/2 & 59.1 & 22.4 & 18.4 & - \\
\hline & & $\mathrm{Bt}$ & $9-22$ & 10YR 4/4 & 59.0 & 26.0 & 15.0 & - \\
\hline & & $B C$ & $22-33$ & 10YR 5/4 & 66.4 & 23.4 & 10.2 & - \\
\hline & & $2 \operatorname{Cox}$ & $33-60+$ & $2.5 Y 6 / 4$ & 83.6 & 11.1 & 5.3 & - \\
\hline \multirow[t]{5}{*}{ SCB3 } & $\mathrm{Pt}$ & $A$ & $0-10$ & 10YR 3/2 & 53.8 & 26.0 & 20.2 & - \\
\hline & & $A B$ & 10-26 & 10YR 4/3 & 69.1 & 16.6 & 14.3 & - \\
\hline & & $2 \mathrm{Bw}$ & $26-48$ & 10YR 5/3 & 76.1 & 19.3 & 4.6 & - \\
\hline & & $2 \operatorname{Cox}$ & $48-65$ & $2.5 Y$ 6/3 & 69.6 & 24.6 & 5.8 & - \\
\hline & & $2 \mathrm{Cu}$ & $65-80+$ & $5 Y 4 / 2(m)$ & 83.0 & 13.8 & 3.2 & - \\
\hline \multirow[t]{5}{*}{ SCB4 } & $\mathrm{Pt}$ & $A$ & $0-7$ & 10YR $3 / 1$ & 52.0 & 27.9 & 20.1 & - \\
\hline & & $\mathrm{Bt}$ & $7-20$ & 10YR $4 / 3$ & 62.9 & 24.8 & 12.3 & - \\
\hline & & $2 \mathrm{BC}$ & $20-43$ & 10YR 5/4 & 62.7 & 29.0 & 8.3 & - \\
\hline & & 2 Cox & $43-55$ & $2.5 Y 6 / 4$ & 50.9 & 38.2 & 10.9 & - \\
\hline & & $2 \mathrm{Cu}$ & 55-65+ & $5 Y 4 / 2(m)$ & 79.0 & 17.1 & 3.9 & - \\
\hline \multirow[t]{5}{*}{ SCB5 } & $\mathrm{Pt}$ & A & $0-10$ & 10YR $3 / 2$ & 66.7 & 18.4 & 14.9 & - \\
\hline & & $\mathrm{Bt}$ & $10-25$ & 10YR 4/2 & 62.5 & 20.5 & 17.0 & - \\
\hline & & $2 \mathrm{BC}$ & $25-52$ & 10YR 5/4 & 76.7 & 17.6 & 5.7 & - \\
\hline & & $2 \operatorname{Cox}$ & $52-62$ & $2.5 Y 6 / 3$ & 67.3 & 25.5 & 7.2 & - \\
\hline & & $2 \mathrm{Cu}$ & $62+$ & $5 Y$ 6/2 & 79.0 & 17.1 & 3.9 & - \\
\hline SCB11 & $\mathrm{Pt}$ & A & $0-9$ & 10YR 3/2 & 51.9 & 30.9 & 17.2 & - \\
\hline & & $\mathrm{Bt}$ & $9-20$ & $10 Y R 4 / 3$ & 43.1 & 36.5 & 20.4 & - \\
\hline & & $2 \mathrm{BC}$ & 20-30 & 10YR 5/4 & 77.9 & 15.8 & 6.3 & - \\
\hline & & $2 \operatorname{Cox} 1$ & $30-45$ & $2.5 Y 5 / 4$ & 77.9 & 18.9 & 3.1 & - \\
\hline & & 2Cox2 & $45-55+$ & $2.5 Y 6 / 3$ & 85.1 & 13.1 & 1.7 & - \\
\hline
\end{tabular}


TABLE 2. LABORATORY DATA FOR SELECTED SOILS, WIND RIVER RANGE, WYOMING (Continued)

\begin{tabular}{|c|c|c|c|c|c|c|c|c|}
\hline \multirow[b]{2}{*}{ Locality } & \multirow[b]{2}{*}{ Age and facies } & \multirow[b]{2}{*}{ Horizon } & \multirow{2}{*}{$\begin{array}{l}\text { Depth } \\
\text { (cm) }\end{array}$} & \multirow{2}{*}{$\begin{array}{l}\text { Color } \\
\text { (d) }\end{array}$} & \multicolumn{3}{|c|}{ Particle-size distribution* $(<2 \mathrm{~mm})$} & \multirow[b]{2}{*}{$\mathrm{pH}^{\star \star}$} \\
\hline & & & & & Sand $(2-0.05)$ & Silt $(0.05-0.002)$ & Clay $(<0.002)$ & \\
\hline \multicolumn{9}{|c|}{ Stough Creek Basin (Fig. 6) } \\
\hline \multirow[t]{6}{*}{ SCB1 } & $\mathrm{Pt}$ & $A$ & $0-6$ & 10YR 4/2 & 56 & 27 & 17 & - \\
\hline & & $E$ & $6-10$ & 10YR $5 / 3$ & 51 & 37 & 13 & - \\
\hline & & 2Bs1 & $10-22$ & 10YR 5/6 & 68 & 23 & 9 & 一 \\
\hline & & 2Bs2 & $22-40$ & $10 Y R 6 / 6$ & 67 & 28 & 5 & - \\
\hline & & 2Cox1 & $40-60$ & $2.5 Y 7.4$ & 66 & 32 & 2 & - \\
\hline & & $2 \mathrm{Cox} 2$ & $60-80+$ & $2.5 Y 7 / 2$ & 65 & 34 & 1 & 一 \\
\hline \multirow[t]{7}{*}{ SCB10 } & $\mathrm{Pt}$ & A & $0-6$ & 10YR 3/2 & 17 & 50 & 33 & - \\
\hline & & $\mathrm{Ej}$ & $6-7$ & 10YR 4/3 & 24 & 50 & 27 & - \\
\hline & & $\mathrm{Bw}$ & $7-11$ & 10YR 3/3 & 41 & 32 & 27 & - \\
\hline & & $2 \mathrm{ABb}$ & $11-23$ & 10YR 4/2 & 58 & 23 & 20 & - \\
\hline & & 2Bwb & 23-29 & 10YR 5/4 & 75 & 16 & 9 & - \\
\hline & & 2Cox1b & $29-75$ & $2.5 Y$ 6/4 & 87 & 8 & 5 & - \\
\hline & & 2Cox2b & $75-85+$ & $2.5 Y 6 / 4$ & 80 & 14 & 6 & - \\
\hline \multirow[t]{6}{*}{ LC1 } & $\mathrm{Pt}$ & 0 & $0-3$ & - & - & - & - & - \\
\hline & & $E$ & $3-6$ & 10YR 5/3 & 66 & 23 & 12 & - \\
\hline & & Bs1 & $6-18$ & 7.5YR 6/6 & 60 & 33 & 7 & - \\
\hline & & Bs2 & $18-45$ & 7.5YR 6/6 & 65 & 28 & 7 & - \\
\hline & & $2 \operatorname{Cox} x$ & $45-80$ & 10YR 6/4 & 74 & 18 & 9 & - \\
\hline & & $2 \mathrm{Cu}$ & $80+$ & $5 Y 7 / 4$ & 65 & 34 & 1 & - \\
\hline \multirow[t]{6}{*}{ WL1 } & $\mathrm{Pt}$ & $\mathrm{AO}$ & $0-5$ & 10YR $5 / 3$ & 79 & 14 & 7 & - \\
\hline & & $\mathrm{Ej}$ & $5-9$ & 10YR 6/4 & 51 & 37 & 12 & - \\
\hline & & $B w$ & $9-30$ & 10YR 6/6 & 63 & 23 & 14 & - \\
\hline & & $2 \mathrm{BCx}$ & $30-52$ & $10 Y R$ 6/4 & 65 & 23 & 12 & - \\
\hline & & 2Coxx & $52-68$ & $2.5 Y 6 / 4$ & 68 & 22 & 10 & - \\
\hline & & $2 \mathrm{Cu}$ & $68+$ & $5 Y 7 / 2$ & 68 & 23 & 9 & - \\
\hline \multirow[t]{8}{*}{ RFP1 } & $\mathrm{Pt}$ & $\mathrm{A} 1$ & $0-5$ & 10YR 3/3 & 35 & 33 & 32 & - \\
\hline & & $\mathrm{A} 2$ & $5-13$ & 10YR 4/3 & 39 & 35 & 26 & - \\
\hline & & Bw1 & $13-24$ & 7.5YR 5/4 & 62 & 23 & 15 & - \\
\hline & & Bw2 & 24-32 & 7.5YR 5/4 & 69 & 19 & 12 & - \\
\hline & & Bw3 & $32-59$ & 10YR 5/6 & 77 & 14 & 9 & - \\
\hline & & $2 \mathrm{BC} 1$ & 59-92 & 10YR 5/6 & 86 & 8 & 7 & - \\
\hline & & $3 B C 2$ & $92-120$ & 10YR 5/4 & 68 & 19 & 13 & - \\
\hline & & 4 Cox & $120+$ & $2.5 Y 5 / 4$ & 73 & 20 & 8 & - \\
\hline \multirow[t]{5}{*}{ RFP2 } & $\mathrm{Pt}$ & $A$ & $0-13$ & 10YR 4/2 & 40 & 36 & 24 & - \\
\hline & & $\mathrm{Bt} 1$ & $13-23$ & 10YR 5/4 & 62 & 22 & 15 & - \\
\hline & & $2 \mathrm{Bt} 2$ & $23-50$ & 10YR 6/4 & 68 & 20 & 12 & - \\
\hline & & $2 B C$ & $50-60$ & 10YR 6/4 & 71 & 20 & 9 & - \\
\hline & & $2 \operatorname{Cox}$ & $60-75+$ & $2.5 Y 6 / 4$ & 73 & 20 & 8 & - \\
\hline
\end{tabular}

${ }^{*}$ Pipette method (Day, 1965).

${ }^{*}$ Soil:water ratio of 1:2.5. 
TABLE 3. SELECTED DATA FOR UNANALYZED SOILS, WIND RIVER RANGE, WYOMING

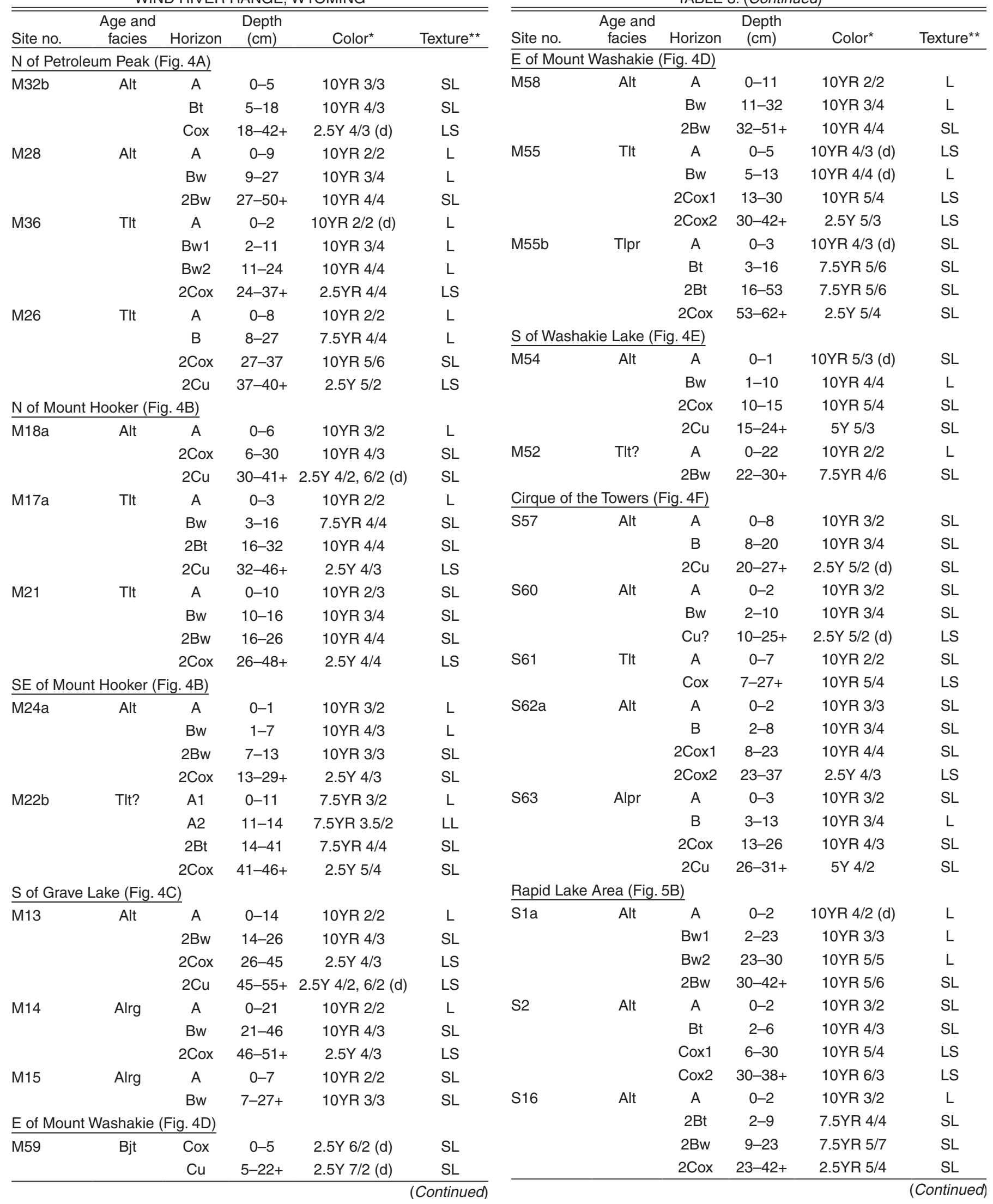


TABLE 3. (Continued)

\begin{tabular}{|c|c|c|c|c|}
\hline Site no. & $\begin{array}{c}\begin{array}{c}\text { Age and } \\
\text { facies }\end{array} \\
\end{array}$ & Horizon & $\begin{array}{l}\text { Depth } \\
\text { (cm) }\end{array}$ & Color* \\
\hline \multicolumn{5}{|c|}{ Temple Lake Area (Fig. 5C) } \\
\hline \multirow[t]{2}{*}{ S52a } & Gpt & Cox & $0-4$ & $5 Y 4 / 2$ \\
\hline & & $\mathrm{Cu}$ & $4+$ & $5 Y 4 / 1$ \\
\hline \multirow[t]{3}{*}{ S6a } & Alrg & A & $0-2$ & 10YR 3/2 \\
\hline & & $\mathrm{Bt}$ & $2-10$ & 10YR $5 / 5 d$ \\
\hline & & $2 \mathrm{Cox}$ & $10-20+$ & $5 Y 5 / 3$ \\
\hline \multirow[t]{4}{*}{ SE of S6a } & Alrg & A & $0-2$ & 10YR $3 / 2$ \\
\hline & & $\mathrm{Bt}$ & $2-8$ & 10YR $5 / 5 d$ \\
\hline & & $\mathrm{Bw}$ & $8-34$ & 10YR $4 / 4$ \\
\hline & & $\mathrm{Cu}$ & $34+$ & $7.5 Y 5 / 2 d$ \\
\hline \multirow[t]{4}{*}{ S7d } & Tlt & A & $0-8$ & 10YR 3/4d \\
\hline & & B & $8-25$ & $10 Y R 3 / 3,5 / 3 d$ \\
\hline & & $2 \mathrm{Cox} 1$ & $25-45$ & 10YR 5/4 \\
\hline & & 2Cox2 & $45-60+$ & 10YR $5 / 2$ \\
\hline
\end{tabular}

NE of East Temple Peak (Fig. 5D)

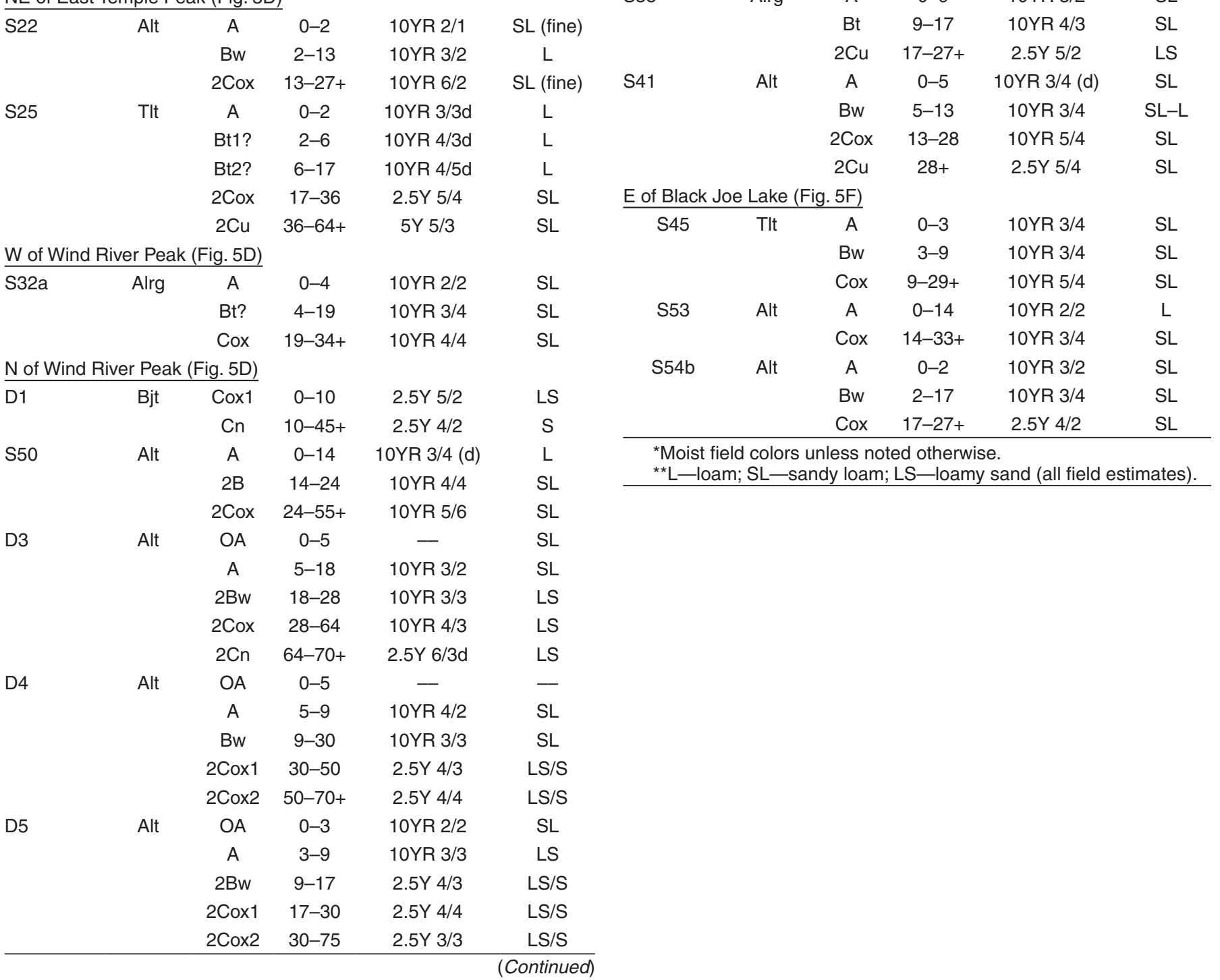

TABLE 3. (Continued)

\begin{tabular}{|c|c|c|c|c|c|}
\hline Site no. & $\begin{array}{c}\text { Age and } \\
\text { facies }\end{array}$ & Horizon & $\begin{array}{l}\text { Depth } \\
\text { (cm) }\end{array}$ & Color* & Texture $^{\star}$ \\
\hline \multicolumn{6}{|c|}{ N of Wind River Peak (Fig. 5D) } \\
\hline \multirow[t]{4}{*}{ D8 } & Alt & OA & $0-4$ & - & - \\
\hline & & $A B$ & $4-12$ & 10YR $2 / 2$ & SL \\
\hline & & Bw & $12-20$ & 10YR $3 / 2$ & SL \\
\hline & & 2Cox & $20-40$ & $2.5 Y 4 / 3$ & LS/S \\
\hline \multirow[t]{4}{*}{ D6 } & Tlt & OA & $0-4$ & 10YR $2 / 2$ & L \\
\hline & & Bw1 & $4-10$ & 10YR $3 / 2$ & SL \\
\hline & & 2Bw2 & ‘10-13 & 10YR $4 / 3$ & LS \\
\hline & & 2 Cox & $13-25+$ & $2.5 Y 4 / 3$ & LS \\
\hline \multirow[t]{4}{*}{ D7 } & Tlt & OA & $0-8$ & 10YR $2 / 1$ & SL \\
\hline & & Bw & $8-17$ & 10YR $2 / 2$ & SL \\
\hline & & $2 \operatorname{Cox} 1$ & $17-30$ & 10YR $4 / 2$ & LS \\
\hline & & 2Cox2 & $30-40+$ & 10YR $4 / 2$ & LS \\
\hline
\end{tabular}

L OR L

SL

N of Black Joe Lake (Fig. 5E)

S38 Alrg A $\quad 0-9$ 10YR 3/2

SL
SL
SL
LS
LS
L
SL OR L
SL
SL
Texture**

SL

$\mathrm{SL}$

$S L$

LS 
have been used previously to help date young tills and rock-glacier deposits in the Wind River Range (Currey, 1974; Miller and Birkeland, 1974; Mahaney, 1978, 1984a, 1984b; Mahaney et al., 1984a, 1984b; Mahaney and Halvorson, 1986; Birkeland et al., 1989; Dahms, 2002, 2004a). Till is an ideal material for soil-development studies in granitic terrain because it commonly is gray when deposited-a color markedly different from colors imparted by pedogenic processes. To avoid the effects of erosion and deposition after till deposition, all soils were described and sampled at sites located on the flattest and hence most stable surfaces available.

Soil-horizon designations follow Birkeland (1999). Ej horizons are slightly lighter in color than either the overlying A or underlying B horizons, probably due to the downward movement of iron under forest conditions; they do not qualify as albic horizons. Two types of B horizons were recognized; those based mainly on color are Bw horizons, whereas those based on both color and an increase in clay content are Bt horizons. Oxidized horizons that do not qualify as Bw horizons are designated as Cox horizons, and unoxidized horizons (parent material) as $\mathrm{Cu}$ horizons.

Typically, the dry color of the sieved $<2 \mathrm{~mm}$ fraction is best for distinguishing among $\mathrm{Cu}$, Cox, and Bw horizons. Unweathered till or rock-glacier parent materials ( $\mathrm{Cu}$ horizons) usually have $2.5 \mathrm{Y}$ and $10 \mathrm{Y}$ hues, values between 4 and 7 , and chromas between 1 and 2.5. Cox horizons are more oxidized than $\mathrm{Cu}$ horizons, and although this distinction is very subtle for some of the youngest soils, most Cox horizons have $2.5 \mathrm{Y}$ or $10 \mathrm{YR}$ hues. In contrast, Bw horizons have a 10YR hue, and some have a 7.5YR hue. Distinguishing between Bw and Cox horizons is difficult. Most of these horizons in this study have 10YR hue; horizons with values of 5 or more are designated Cox, and those with values of 4 or less are designated $\mathrm{Bw}$. We have no way of determining the original color of loess because, at the sites studied, loess deposits are thin enough to have been altered by pedogenic processes. All subsurface horizons formed in loess are $\mathrm{Bw}$ or Bt horizons.

Bt horizons are weakly developed in our study area, and not all workers may accept our criteria for designating argillic (Bt) horizons. Modified criteria for identifying Bt horizons (Soil Survey Staff, 1999) were used. Bt horizons formed in loess have at least 1.2 times more clay than the overlying A horizons. If, however, the parent material of the Bt horizon is till or rock-glacier material, the Bt horizon has to have at least 3 percent more clay than the underlying Cox horizon. In both above cases, we judge that most of the fines have been translocated from the horizon(s) overlying the Bt.

Arabic numerals in front of the master horizon designation indicate parent material layering. When no such numbers are used; the soil is formed in the same glacial or periglacial deposit. In older soils, however, it is common to have non-gritty material (loess or loess mixed with coarser materials) overlying gritty parent materials. In these soils the lower deposit is identified by a " 2 " in front of the soil horizon designation.

\section{USE OF RELATIVE-AGE DATA}

Each RA method used in this study has limitations in its usefulness to differentiate and correlate map units (Birkeland, 1973, figure 11 therein). Because of these limitations, we do not feel confident in using any single method to the exclusion of others. Hence, after all the data were collected (Tables 2-6), we tried to determine which data may be most meaningful and which may be the least useful at each site and come to a consensus as to the age assignment for the deposit. Using this approach we feel confident in consistently assigning deposits to one of the four alloformations in most cirques (Figs. 3-6). At a few sites where the data were conflicting, we have indicated this on the maps and assigned two possible ages to the map unit. Stough Creek Basin stratigraphy map units (Fig. 6) are based mainly on soils and lichen data (Dahms and Birkeland, 2000; Dahms, 2002).

\section{DESCRIPTIONS OF TYPE LOCALITIES OF ALLOFORMATIONS}

The type localities of the four alloformations are on till. RA data are included in Tables 2-6; data presented below are for those sites, and the range of each data set is given in Figure 7 and Table 1.

\section{Gannett Peak Alloformation}

The type locality for the Gannett Peak alloformation is on three right-lateral moraines at the foot of the Gannett Glacier near Gannett Peak in the northern part of the Wind River Range (site N1, Fig. 3). These moraines were originally described by Richmond (1957, 1965). Vegetation cover is sparse, consisting of widely scattered grasses and vascular plants at the few locations where enough sand and finer materials exist to support plants and promote soil formation. Surface boulders are unweathered and show no signs of oxidation. Lichen cover on boulders reaches a maximum of $\sim 5$ percent, and is found on only a few boulders. Few $R$. geographicum, s.l. thalli were observed. The soil consists of subtle oxidation in a 6-cm-thick incipient Cox horizon of $5 \mathrm{Y}$ $5 / 2$ dry color overlying a $\mathrm{Cu}$ horizon of $5 \mathrm{Y} 7 / 1$ dry color.

Gannett Peak till, as described here, includes the youngest deposits of the cirque moraines of Moss (1951b), the Gannett Peak moraines of Richmond (1965), the later neoglacial moraine of Currey (1974), and the Gannett Peak till of Miller and Birkeland (1974) and Dahms (2002). There is some debate whether till of the Gannett Peak moraine of Mahaney et al. (1984a, 1984b) and Mahaney (1988) is Gannett Peak till or Black Joe till (Dahms, 2002).

\section{Black Joe Alloformation}

The type locality for the Black Joe alloformation is on two left-lateral moraines in an unnamed cirque located $3 \mathrm{~km}$ south of Black Joe Lake in the southern Wind River Range (site S30, 
TABLE 4. LICHENOMETRIC, ROCK-WEATHERING, AND LOESS-THICKNESS DATA FOR FIGURE 3, WIND RIVER RANGE, WYOMING

\begin{tabular}{|c|c|c|c|c|c|c|c|c|c|c|c|c|c|}
\hline \multirow[b]{2}{*}{ Site no. } & \multirow[b]{2}{*}{$\begin{array}{c}\text { Age and } \\
\text { facies }^{\dagger}\end{array}$} & \multicolumn{5}{|c|}{ Maximum diameter of lichen thalli $(\mathrm{mm})$} & \multirow{2}{*}{$\begin{array}{c}\text { Maximum } \\
\text { lichen } \\
\text { cover } \\
(\%)\end{array}$} & \multirow{2}{*}{$\begin{array}{c}\text { Average } \\
\text { lichen } \\
\text { cover } \\
(\%)\end{array}$} & \multirow[b]{2}{*}{$\begin{array}{l}\text { Surface } \\
\text { oxidation } \\
\text { of boulders }\end{array}$} & \multicolumn{3}{|c|}{ Rock weathering characteristics } & \multirow[b]{2}{*}{$\begin{array}{l}\text { Loess } \\
\text { thickness } \\
\text { (cm) }\end{array}$} \\
\hline & & R.g. & L.t. & L.atro. & L.asp. & C.e. & & & & $\begin{array}{c}\% \\
\text { weathered }\end{array}$ & $\begin{array}{c}\% \\
\text { pitted }\end{array}$ & $\begin{array}{c}\text { Maximum } \\
\text { depth of pitting } \\
(\mathrm{mm})\end{array}$ & \\
\hline N6 & Gpt & 0 & 0 & 0 & 0 & 0 & 0 & 0 & 0 & 0 & 0 & 0 & 0 \\
\hline $\mathrm{N} 1$ & Gpt & 0 & 20 & 9 & 42 & 45 & 5 & 0 & 0 & 0 & 0 & 0 & 0 \\
\hline N7 & Gpt & 4 & 61 & 29 & 55 & 37 & 5 & 0 & 0 & 0 & 0 & 0 & 0 \\
\hline N2 & Bjt & 42 & 108 & 82 & 116 & 35 & 50 & $5-15$ & sl. ox. & - & - & incipient & 0 \\
\hline N5 & Alt & 82 & - & - & - & - & $85-90$ & - & ox. & 21 & 19 & $75-90$ & 11 \\
\hline N8 & Tlt & $60-70$ & - & - & - & - & $85-90$ & - & ox. & - & - & 75 & 27 \\
\hline \multicolumn{14}{|l|}{ N9 } \\
\hline \multicolumn{14}{|l|}{ N13 } \\
\hline N14 & Gpty & 0 & 0 & 0 & 0 & 0 & 0 & 0 & 0 & 0 & 0 & 0 & 0 \\
\hline N12 & Gpty & 0 & 3 & 0 & 0 & 13 & 1 & 0 & 0 & 0 & 0 & 0 & 0 \\
\hline N16 & TIt & $>90$ & - & - & - & - & $85-90$ & - & ox. & - & - & 120 & 18 \\
\hline N17 & Tlt & - & - & - & - & - & - & - & ox. & 17 & 18 & 120 & 17 \\
\hline
\end{tabular}

and the next moraine to the north, Figs. 5, 5D). Here, Black Joe till lies immediately down valley of Gannett Peak till. Black Joe moraines generally have less than 5-10 percent cover of vascular plants. The till is bouldery and contains a few slightly oxidized boulders. Some boulders are pitted to depths of 20-30 mm and only 2 percent are weathered. Lichen cover on individual boulders reaches 30 percent, whereas lichen cover for the site is 15-20 percent, with $L$. thompsonii (largest diameter, $115 \mathrm{~mm}$ ) and L. atrobrunnea (largest diameter, $124 \mathrm{~mm}$ ) being the dominant lichen species. Thalli of $R$. geographicum, s.l. reach $48 \mathrm{~mm}$. The characteristic soil developed in Black Joe till is not well expressed at the type locality; a more characteristic soil with an A/Cox/Cu profile is at S19, north of East Temple Peak (Fig. 5D).

Black Joe till includes deposits in the Wind River Range referred to earlier as possible Audubon equivalent till (Miller and Birkeland, 1974; Dahms, 2002), Audubon advance (Mahaney et al., 1984a, 1984b; Mahaney, 1988), and Audubon moraine (Mahaney et al., 1984a, 1984b; Mahaney, 1988; Richmond, 1986).

\section{Alice Lake Alloformation}

The type locality of the Alice Lake alloformation is located $\sim 200 \mathrm{~m}$ northeast of Alice Lake, near the headwall of the cirque above Temple Peak (sites S11, S12, S13; Fig. 5C). The three prominent moraines at the type locality are located $\sim 2-2.5 \mathrm{~km}$ upvalley from the type locality for the Temple Lake till and several hundred meters downvalley from the Gannett Peak and Black Joe moraines (just below the lower limit of the unnamed glacier on the north side of Temple Peak). The surface of the Alice Lake till at its type locality is stable and moraine crests support 20 30 percent alpine turf cover between boulders. A fairly advanced degree of weathering and lichen colonization characterizes this till relative to younger tills. Surface boulders generally are weathered and pitted, (30 and 44 percent, respectively), maximum pit depths reach $80 \mathrm{~mm}$, and K-feldspar phenocrysts commonly protrude $20 \mathrm{~mm}$ above clast surfaces. Lichen cover reaches 80 85 percent on most boulders, and the largest $R$. geographicum, s.l. is $107 \mathrm{~mm}$. The soil has an A/Bt/Cox profile at least $66 \mathrm{~cm}$ thick, with a maximum hue of 10YR. The Bt horizon is subtle and only $9 \mathrm{~cm}$ thick. Loess is less than $13 \mathrm{~cm}$ thick.

Alice Lake till includes part of the multiple cirque moraines of Moss (1951a, 1951b), the earlier neoglacial moraines of Currey (1974), the early Neoglacial till of Miller and Birkeland (1974), and probably the Indian Basin ground moraine of Mahaney (1988).

\section{Temple Lake Alloformation}

The type locality of the Temple Lake alloformation is on till that forms a broad, low, turf-covered end/lateral moraine on the northeast margins of Miller and Temple lakes north of Temple Peak (sites S5a, S6b, S7c; Fig. 5C). The moraine lies within $2.5 \mathrm{~km}$ of the headwall of the cirque above the south shore of the lake, and was produced by a glacier advancing northeastward from a series of steep cirque headwalls on the west side of the valley.

An extensive turf cover, partial cover of krumholz vegetation, and advanced weathering characterize Temple Lake till. 


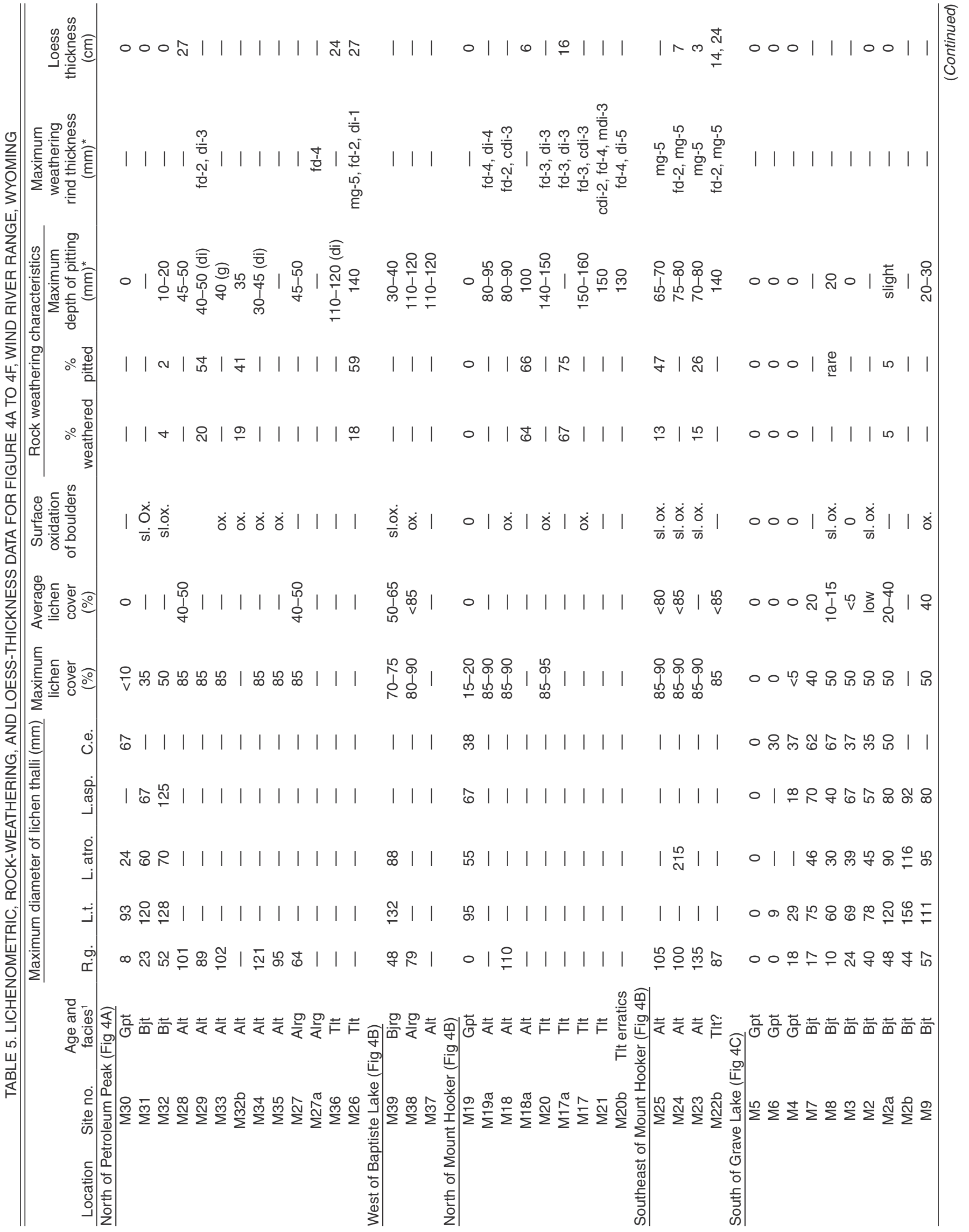




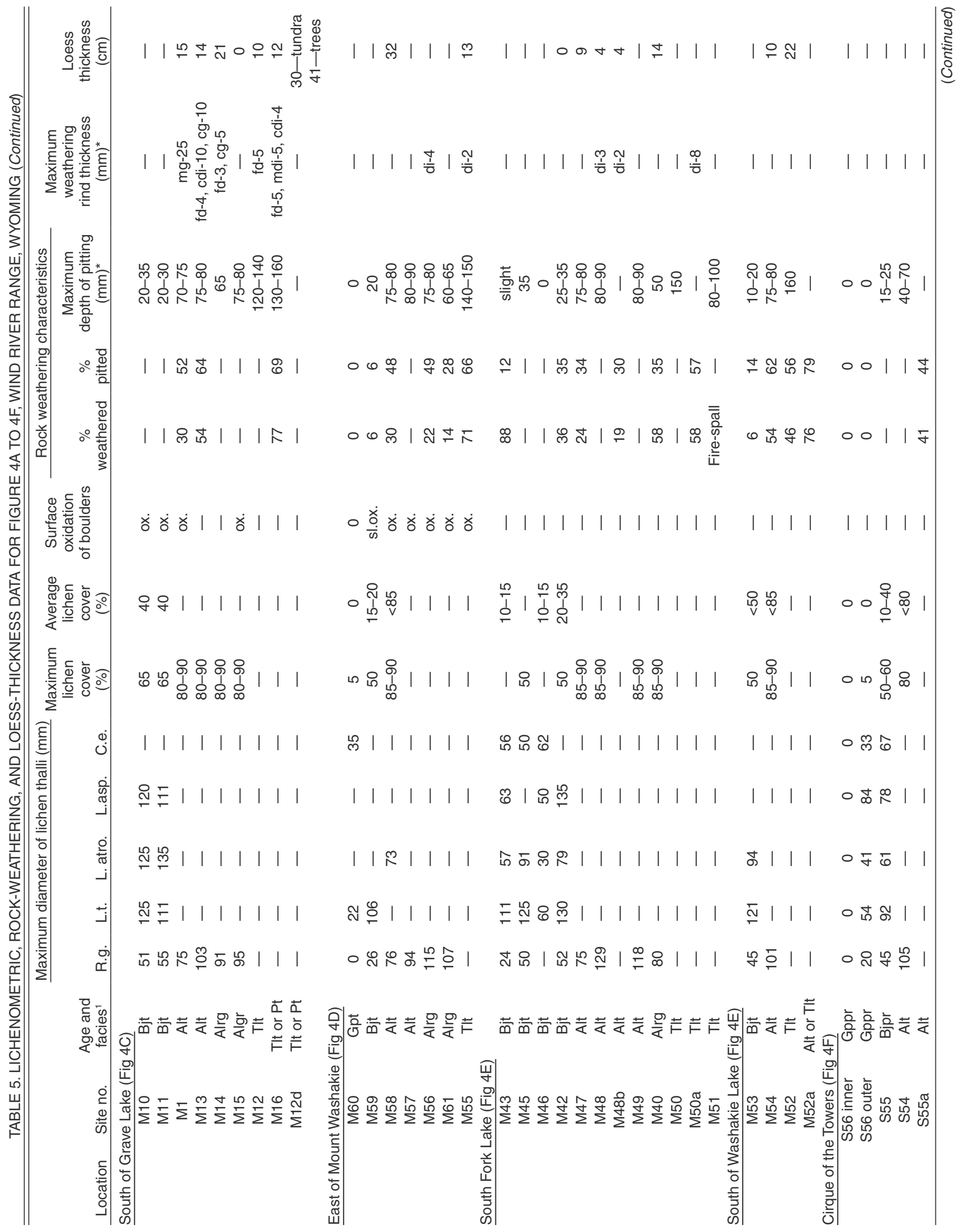




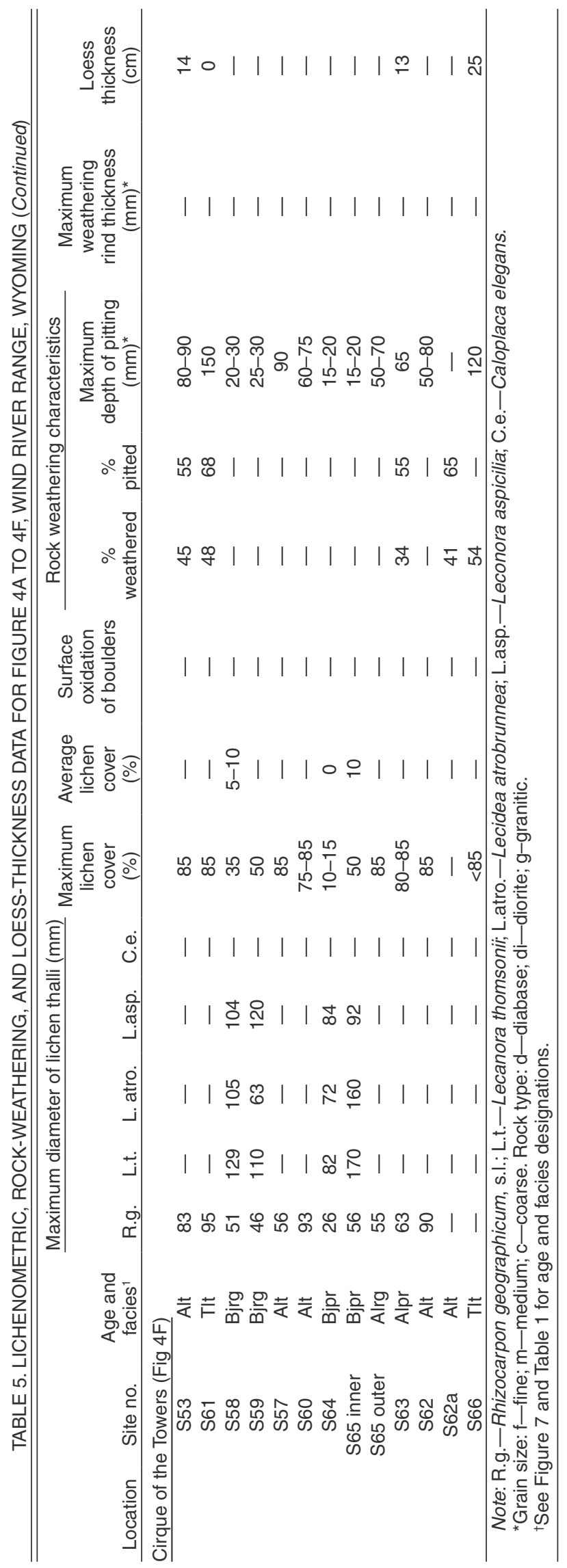









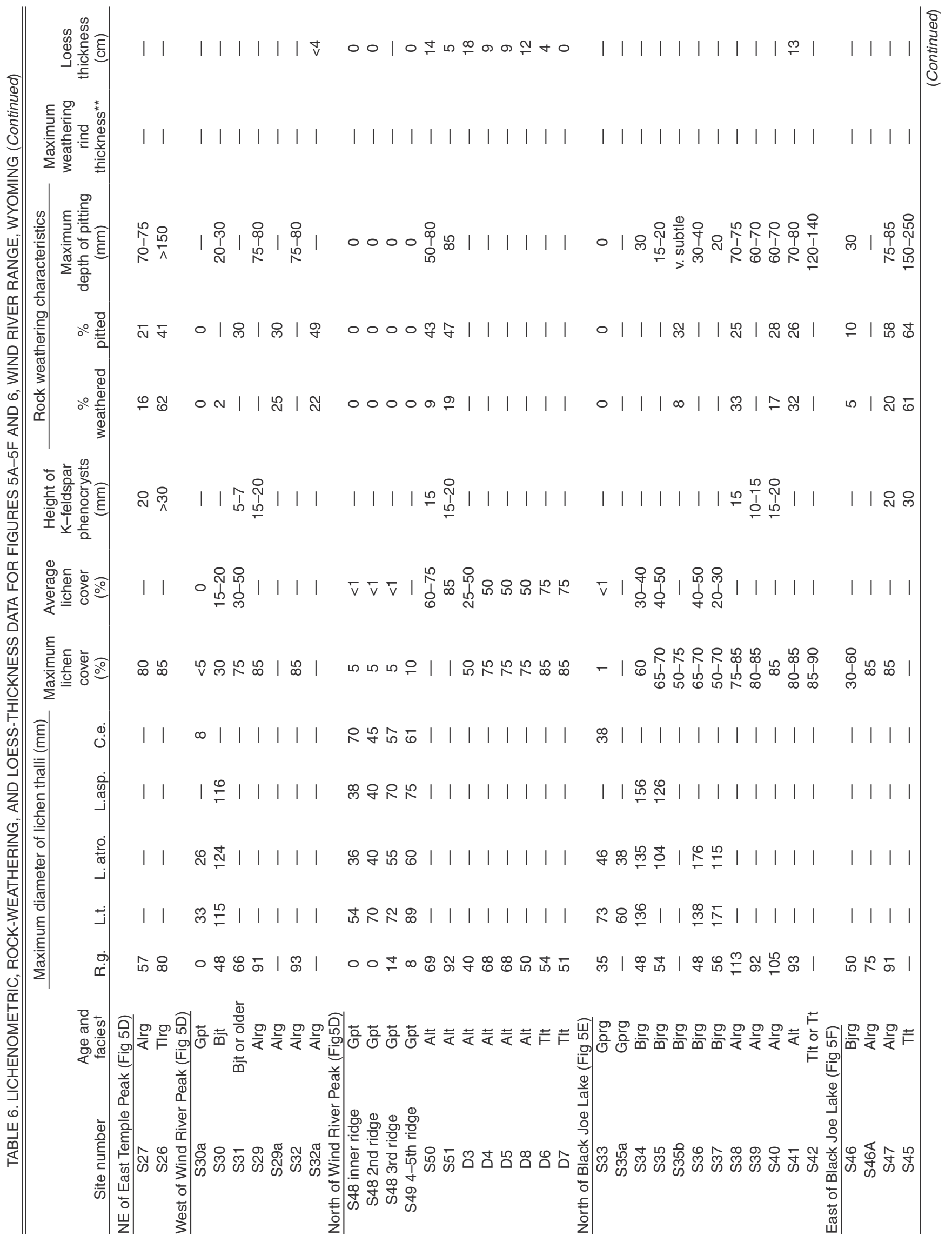




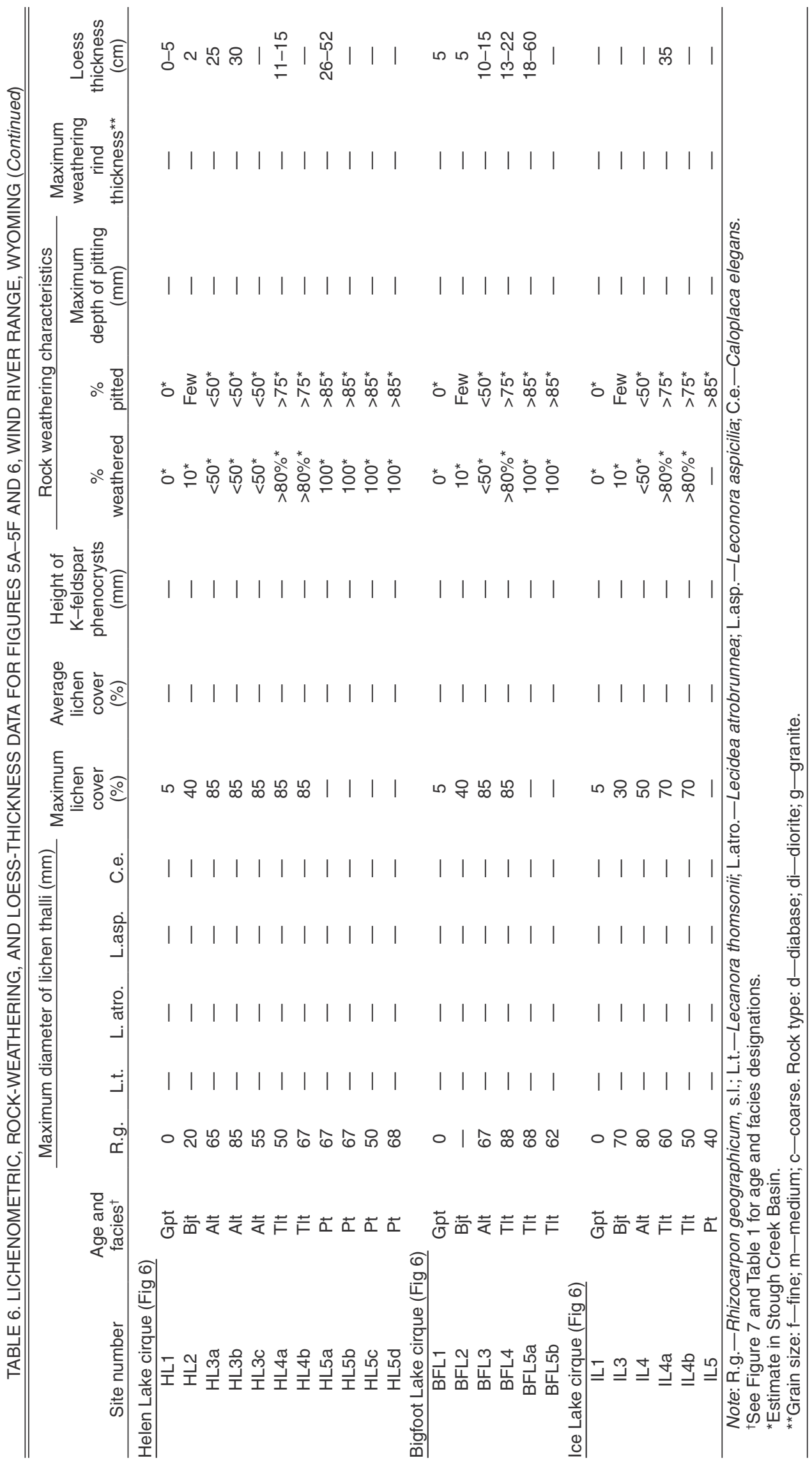


Degree of boulder weathering, depth of boulder pitting, and loess thickness are 50-100 percent greater than those values measured on Alice Lake till (Tables 4-6). Soils are characterized by $\mathrm{A} / \mathrm{Bt} / \mathrm{Cox}$ profiles. These soils have more clay and stronger 10YR and 7.5YR colors relative to the soils developed in Alice Lake till (Tables 2, 3).

Temple Lake till includes the deposit referred to as the Temple Lake Moraine by Hack (1943) and Moss (1951a, 1951b), most of the deposits mapped as Temple Lake Moraine by Currey (1974), and Temple Lake till of Miller and Birkeland (1974). Till in a similar down-valley position in Titcomb Basin in the northern part of the range is mapped as Pinedale by Mahaney et al. (1984a), but ${ }^{14} \mathrm{C}$ and ${ }^{10} \mathrm{Be} /{ }^{26} \mathrm{Al}$ analyses demonstrate that it is coeval with Temple Lake till at its type locality (Zielinski and Davis, 1987; Gosse et al., 1995a, 1999, 2003).

\section{APPROXIMATE AGES OF ALLOFORMATIONS}

Recent work has generated a body of numeric-age data for deposits coeval with deposits of the Temple Lake alloformation, but there is little numeric age control for our other alloformations in this study. Radiocarbon ages and ${ }^{10} \mathrm{Be}$ and ${ }^{26} \mathrm{Al}$ exposure ages from boulders help limit the age of Temple Lake till, whereas ${ }^{14} \mathrm{C}$ and lichen growth rate age estimates provide limits for Alice Lake till. The ages of the other alloformations are estimated only by maximum sizes and growth rates of $R$. geographicum, s.1.

\section{Deposits of Pinedale Glaciation}

The only deposits of the Pinedale glaciation in the alpine valleys of this study are considered to be recessional moraines and (or) stagnant-ice deposits. As such, these Pinedale deposits are younger than the Pinedale terminal moraines mapped along the mountain front ca. 20-30 km downvalley from deposits discussed here (Gosse et al., 1995b, 2003; Chadwick et al., 1997). The only numeric ages available for deposits of the Pinedale glaciation mapped in this study are those related to Dahms' work in Stough Creek Basin (2002; unpublished data). Preliminary exposure ages of $14,400 \pm 1.4$ and $14,500 \pm 1.4{ }^{10} \mathrm{Be}$ yr were obtained from two boulders on lateral (recessional?) moraines mapped on the eastern valley wall (Fig. 6; D. Fabel, 2009, written commun.).

\section{Temple Lake Alloformation}

One radiocarbon sample collected by Miller and Birkeland (1974) provides a minimum age for Temple Lake till. The date is on charcoal from a buried A horizon at 25-27 cm depth at site N8, Gannett Glacier area (Fig. 3). The buried A horizon is part of a soil formed in Temple Lake till, and the overlying sediment is interpreted as loess. The date, $4500 \pm 650{ }^{14} \mathrm{C}$ yr B.P. (GX 4241), is a minimum age for the underlying till, and a maximum for the overlying loess. The overlying loess probably predates the Black Joe till, because the latter generally lacks a surface loess deposit.
Radiocarbon ages obtained by other workers at its type locality (Fig. 5C) indicate a much older minimum age for Temple Lake till. Currey (1974) reports an age of $6500 \pm 230{ }^{14} \mathrm{C}$ yr B.P. on organic matter in sediment that overlies the till, and Zielinski and Davis (1987) obtained an even older age of $11,400 \pm 630{ }^{14} \mathrm{C} \mathrm{yr} \mathrm{B.P.}$ for basal gyttja in a core from a lake that lies on the till. The latter date indicates that the till is latest Pleistocene in age.

Corroboration for a latest Pleistocene age for Temple Lake till comes from Gosse et al. (1995a, 2003) in Titcomb Basin, immediately south of the Gannett Glacier locality, and from Dahms (2002) in Stough Creek Basin. Gosse et al. (2003) report mean exposure ages of $12.9{ }^{10} \mathrm{Be}$ yr B.P. and $13.1{ }^{26} \mathrm{Al}$ yr B.P. from erratics on Mahaney's (1978) late Pinedale moraine situated between upper and lower Titcomb Lakes. Thus, the tills of Mahaney's (1978) late Pinedale moraines (1978) seem to correlate with Temple Lake till at its type locality. Additionally, Gosse et al. (1999) obtained lake-bottom ${ }^{14} \mathrm{C}$ ages of ca. $10,000{ }^{14} \mathrm{C}$ yr B.P. (ca. 11,400 cal yr B.P.) from sediments in upper Titcomb Lake. All of these data support Zielinski and Davis' (1987) correlation of Temple Lake till at its type locality with the Younger Dryas climatic event. Furthermore, Dahms (2002) reported preliminary ${ }^{10} \mathrm{Be}$ exposure ages (production rate based on Lal's 1991 scaling) of $14.6 \pm 2.1$ and $15.7 \pm 2.3 \mathrm{k}$.y. B.P. from striated bedrock on the cirque lip (riegel) $0.6 \mathrm{~km}$ downvalley from the Temple Lake moraine in Bigfoot Lake cirque (Fig. 6). These ages suggest ice was absent from this location prior to the purported advance of Temple Lake ice during the Younger Dryas.

\section{Alice Lake Alloformation}

We estimate the age of the Alice Lake alloformation to be ca. 3800-6000 yr B.P. Two radiocarbon ages obtained for this study provide minimum limiting dates for deposition of the alloformation. One age is on charcoal at $37-38 \mathrm{~cm}$ depth in stream alluvium located just upstream from site M48, south of South Fork Lakes (Fig. 4E). Field relations indicate that the alluvium postdates the till, therefore the age of $2415 \pm 174{ }^{14} \mathrm{C}$ yr B.P. (GX 3240) is a minimum age for Alice Lake till. The second age is on finely divided humic materials from a depth of 59-64 cm in a bog that overlies Alice Lake till at site N10b at the Dinwoody Glacier area (Fig. 3). The total depth of the bog deposit is unknown, but it is $>69 \mathrm{~cm}$ deep, and consists mainly of an organic-rich loam (10YR $2 / 1$ moist color). We consider the age of the organic material, $3895 \pm 190{ }^{14} \mathrm{C}$ yr B.P. (GX 3242), to be the most reliable of the above two minimum limiting ages for the Alice Lake till. Since the charcoal at South Fork Lakes could have been washed to its collected position at any time after deposition of the moraine, it is likely the older (bog) date is closer to the true age of the till, although still a minimum age.

Age estimates from lichen diameters vary from ca. 4000 to ca. 6000 yr B.P., depending on the growth rates used for the calculations. We consider that the use of the largest measured lichen diameter to calculate growth rate results in a minimum limiting age for a deposit because (1) an unknown period of time elapses 
before lichens colonize a site, (2) when the largest lichen isn't equidimensional, we prefer to measure the smaller lichen diameter (rather than the largest) to avoid measuring two intergrown thalli, and (3) the lichens may have experienced snow kill.

The largest $R$. geographicum, s.l. thallus we measured on a deposit of the Alice Lake alloformation is $138 \mathrm{~mm}$ in diameter. Growth rates of 3.0-3.3mm/100 yr (see "Lichen Parameters" above) suggested by Benedict $(1967,1985)$ and Mahaney (1987) result in minimum age calculations of ca. $4180-4600 \mathrm{yr}$ B.P. If, however, we use Dahms' (2002) growth rate of $2.4 \mathrm{~mm} / 100 \mathrm{yr}$ (calculated from the average of the five largest minimum thalli diameters (Tables 4-6), a $138 \mathrm{~mm}$-diameter lichen might be as old as ca. 5750 yr. Recall, however, that the lichen growth-rate curve is estimated to be reliable only to ca. $3000 \mathrm{yr}$ B.P., because senescence apparently begins after this (see Benedict 1967). Ages older than ca. $3000 \mathrm{yr}$ B.P. estimated from lichen diameters can only be minimum limiting ages.

Our estimate of the age of the Alice Lake deposits includes more than estimates from minimum limiting ${ }^{14} \mathrm{C}$ ages and lichen growth rates. Using lichen growth data alone, the Alice Lake deposits appear only slightly older than the Black Joe deposits (ca. 2000 versus ca. 3800 yr B.P.). Soil and boulder weathering data, however, suggest a larger age difference. Soil horizons are distinctly more developed on Alice Lake moraines than on Black Joe moraines. When we account for differences in soil development between Black Joe and Alice Lake deposits, age-related parameters such as clay percent in B horizons, B horizon thickness, and profile thickness (A-B-Cox horizons) are significantly more developed in Alice Lake deposits than in Black Joe deposits (Tables 2-3). No Black Joe soils exhibit B horizons while Bt horizons are common in Alice Lake soils (Tables 2-3). It is reasonable to conclude that the Alice Lake deposits are considerably older than the minimum-limiting bog and lichen age estimates.

The work of Zielinski (1989) has important implications concerning our age assignments based on RA data. Zielinski cored lake sediments in Miller and Rapid Lakes (Figs. 5, 5B) and performed detailed analyses of particle size, organic carbon, extractable $\mathrm{Fe}$, and clay mineralogy. The oldest radiocarbon age from the Miller Lake sediment core is $8300 \pm 475{ }^{14} \mathrm{C} \mathrm{yr}$, and that from the Rapid Lake core is $11,770 \pm 710{ }^{14} \mathrm{C} \mathrm{yr}$.

Our mapping indicates that Alice Lake rock glacier deposits border the west shores of both lakes. Zielinski (1989) argues that these rock glacier deposits are too young to be assigned to the Alice Lake alloformation. He suggests that as they advanced into the lakes, Alice Lake age rock glaciers (extending to the lakes' edge) should have produced a diagnostic clastic layer on the lake floors above these two dated layers. Neither core, however, records a major period of clastic sedimentation younger than (above) the two dated intervals (ca. 8300 and ca. 11,700 yr B.P.) that can be attributed to the presence of rock glaciers. He identifies a minor clastic layer in one core that could possibly have been produced by a rock glacier advance $\sim 7500$ years ago, but he prefers an older age for this layer. Three interpretations are possible of Zielinski's data are possible: (i) our RA-based age estimates for these rock-glacier deposits are too young; (ii) these rock-glacier deposits postdate the lake sediments in Zielinski's cores; or (iii) the rock-glacier may have produced clastic sediment that did not extend far enough in the lake to appear in Zielinski's cores.

Fall et al. (1995) produce pollen data and additional ${ }^{14} \mathrm{C}$ analyses of Zielinski's cores and place the beginning of neoglaciation in Temple Lake valley at ca. $3300{ }^{14} \mathrm{C}$ yr B.P. Preliminary analyses of cores elsewhere in the Wind River Range, however (from upper and lower Titcomb Lakes in the northern part of the range), suggest neoglaciation began as early as $9500-8000 \mathrm{cal}$ yr B.P. or as late as 6000-5300 cal yr B.P. (Gosse et al., 1999; J.C. Gosse, 2000 , written commun.). We presently assign a minimum age of ca. $4000 \mathrm{yr}$ B.P. for deposition of the Alice Lake alloformation based on our lichen data and the ostensible lag time between deposition of till and the formation of $>5 \mathrm{~cm}$ of organics in the bog below Dinwoody Glacier. Our soil development and boulder weathering characteristics, however, as well as the Titcomb Lakes' core data (above) suggest this alloformation could be as old as or older than $6000 \mathrm{yr}$ B.P.

\section{Black Joe Alloformation}

No radiocarbon ages are presently available for deposits of the Black Joe alloformation. The largest $R$. geographicum, s.l. thallus on a boulder assigned to the Black Joe alloformation has a diameter of $70 \mathrm{~mm}$ (Table 5, Ice Lake, Fig. 6). This diameter suggests a minimum age of between 1842 and 1944 yr B.P., using Benedict's (1985) and Mahaney's (1987) growth-rate curves. Use of the 3.0-3.3 mm/yr growth rates appear more appropriate on Black Joe deposits than for the older deposits (above) because senescence would not appear to be a problem on the younger deposits (Benedict 1967, 1985). That is, growth rate estimates from maximum diameters seem more appropriate here than averages of minimum diameter thalli measurements. When we compare our lichen, boulder weathering, and soil data from the Black Joe units to adjacent Gannett Peak and Alice Lake units (Tables 4-6), the use of Dahms' (2002) $2.4 \mathrm{~mm} / 100 \mathrm{yr}$ growth rate results in anomalous lichen age-estimates (ca. 2900 yr B.P.). Thus, we consider the Black Joe alloformation to be no older than ca. 2000 yr B.P.

\section{Gannett Peak Alloformation}

The largest, $R$. geographicum, s.l. thallus on a deposit assigned to the Gannett Peak alloformation has a diameter of $35 \mathrm{~mm}$ (Table 5, north of Black Joe Lake, Fig. 5E), which suggests an age of ca. $700 \mathrm{yr}$ B.P., using Mahaney's (1987) growthrate $(3.0 \mathrm{~mm} / 100 \mathrm{yr})$ and including the "great growth period" described by Benedict (1967). In some cirques, Gannett Peak deposits could be considerably younger based on lichen and other parameters (Tables 4-6). For example, at site N9 (Fig. 3) sand- and pebble-sized material still rests on the tops of large glacial erratics, suggesting deposition within the twentieth century. 


\section{SUMMARY}

Relative-age (RA) criteria are used to quantify postdepositional alteration of glacial and periglacial deposits in the Wind River Range, west-central Wyoming. We distinguished and mapped deposits of latest Pleistocene and Holocene age on the basis of these RA criteria. Map units are till, rock-glacier, protalus-rampart, and rockfall deposits (facies) of four alloformations. All type localities are on till.

The oldest unit is the Temple Lake alloformation of latest Pleistocene age. Its type locality was described by Hack (1943) and Moss (1951a, 1951b) in the southern part of the Wind River Range. The progressively younger Alice Lake and Black Joe alloformations are of Holocene age; their type localities are near that of the Temple Lake. The youngest unit is the Gannett Peak alloformation. Its type locality is near Gannett Peak in the northern area of the Wind River Range (Richmond, 1957, 1965). Radiocarbon ages from this and other studies, along with relative-age data that include soil development characteristics, lichen size-age estimates, and boulder weathering parameters, provide chronologic control for the map units and suggest the following broad age estimates: Temple Lake is coeval to the Younger Dryas (Alley et al., 1993) at ca. 12,000 yr B.P.; Alice Lake is greater than $4000 \mathrm{yr}$ B.P. and possibly as old or older than ca. 6000 yr B.P.; Black Joe is ca. 1700-2000 yr B.P.; and Gannett Peak ranges from 750 to $150 \mathrm{yr}$ B.P. We anticipate future cosmogenic radionuclide $\left({ }^{10} \mathrm{Be},{ }^{26} \mathrm{Al}\right.$, etc $)$ age estimates will help constrain the ages of these deposits, using our maps as a guide to sample sites.

\section{ACKNOWLEDGMENTS}

Helpful field visits were had with D.R. Currey, G.M. Richmond, and S.E. White. Mark Anders assisted us during the first summer. Sue and Karl Birkeland, Dick and Betty Bloomer, Eric Miller, Gerry Richmond, and Jack Shields helped us by transporting gear and samples. Dahms thanks Allyson Anderson (1996) as well as Ron Sammons and Jeff Bertel (2000) for their help as field assistants. Robin Birkeland and Marsha Simpkins typed pre-computer drafts of the manuscript. This work was supported by the U.S. Geological Survey and by grants to Birkeland and (or) Miller from the Geological Society of America, the University of Colorado Council on Research and Creative Work, the Colgate Research Council, and Colgate University. Grants to Dahms from the University of Northern Iowa Graduate College (Summer Fellowships 1994, 1996, 2000) and a sub award under National Science Foundation \#SBR9631437 provided support for the work in Stough Creek Basin and Deep Creek Lakes cirque. The University of Missouri's Department of Geological Sciences kindly provided field support for Dahms at Camp Edwin B. Branson during 1993-1996, and Birkeland and Dahms during 2000. This manuscript was greatly improved by thorough reviews of an early version of the manuscript by D.R. Crandell and R.D. Miller. W.E. Scott, J.
Pitlick, J.C. Gosse, and R.D. Hall reviewed a later version of the manuscript. A recent version of the manuscript benefitted from a thoughtful review by Margaret Berry.

\section{REFERENCES CITED}

Alley, R.B., Meese, D.A., Shuman, C.A., Gow, A.J., Taylor, K.C., Grootes, P.M., White, J.W.C., Ram, M., Waddington, E.D., Mayewski, P.A., and Zielinski, G.A., 1993, Abrupt increase in Greenland snow accumulation at the end of the Younger Dryas Event: Nature, v. 362, p. 527-529, doi: 10.1038/362527a0.

Barry, R.G., 1973, A climatological transect along the east slope of the Front Range, Colorado: Arctic and Alpine Research, v. 5, p. 89-110, doi: $10.2307 / 1550251$.

Benedict, J.B., 1967, Recent glacial history of an alpine area in the Colorado Front Range, USA-I. Establishing a lichen-growth curve: Journal of Glaciology, v. 6, p. 817-832.

Benedict, J.B., 1968, Recent glacial history of an alpine area in the Colorado Front Range, USA-II. Dating the glacial deposits: Journal of Glaciology, v. 7, p. 77-87.

Benedict, J.B., 1973, Chronology of cirque glaciation, Colorado Front Range: Quaternary Research, v. 3, p. 584-599, doi: 10.1016/0033-5894 (73)90032-X.

Benedict, J.B., 1981, The Fourth of July Valley: Ward, Colorado, Center for Mountain Archeology, Research Report No. 2, 139 p.

Benedict, J.B., 1985, Arapaho Pass: glacial geology and archaeology at the crest of the Colorado Front Range: Ward, Colorado, Center for Mountain Archaeology, Research Report 3, 197 p.

Benedict, J.B., 1988, Techniques in lichenometry: Identifying the yellow Rhizocarpons: Arctic and Alpine Research, v. 20, p. 285-291, doi: $10.2307 / 1551260$.

Beschel, R.E., 1957, A project to use lichens as indicators of climate and time: Arctic, v. 10, p. 60.

Birkeland, P.W., 1973, Use of relative age dating methods in a stratigraphic study of rock glacier deposits, Mount Sopris, Colorado: Arctic and Alpine Research, v. 5, p. 401-416, doi: 10.2307/1550131.

Birkeland, P.W., 1999, Soils and Geomorphology: New York, Oxford University Press, $430 \mathrm{p}$.

Birkeland, P.W., Crandell, D.R., and Richmond, G.M., 1971, Status of Correlation of Quaternary stratigraphic units in the western conterminous United States: Quaternary Research, v. 1, p. 208-227, doi: 10.1016/0033 -5894(71)90042-1.

Birkeland, P.W., Colman, S.M., Burke, R.M., Shroba, R.R., and Meierding, T.C., 1979, Nomenclature of alpine glacial deposits, or, what's in a name?: Geology, v. 7, p. 532-536, doi: 10.1130/0091-7613(1979)7<532: NOAGDO $>2.0 . \mathrm{CO} ; 2$.

Birkeland, P.W., Burke, R.M., and Shroba, R.R., 1987, Holocene Alpine Soils in Gneissic Cirque Deposits, Colorado Front Range: U.S. Geological Survey Bulletin 1590-E, 21p.

Birkeland, P.W., Burke, R.M., and Benedict, J.B., 1989, Pedogenic gradients for iron and aluminum accumulation and phosphorus depletion in arctic and alpine soils as a function of time and climate: Quaternary Research, v. 32, p. 193-204, doi: 10.1016/0033-5894(89)90075-6.

Boulding, B.H., and Boulding, J.R., 1981, Genesis of Silty and Clayey Material in some Alpine Soils in the Teton Mountains, Wyoming and Idaho: Indiana Academy of Science Proceedings, v. 91, p. 552-562.

Burke, R.M., and Birkeland, P.W., 1983, Holocene glaciation in the mountain ranges of the western United States, in Wright, H.E., Jr., ed., LateQuaternary Environments of the United States, The Holocene: Minneapolis, University of Minnesota Press, v. 2, p. 3-11.

Chadwick, O.A., Hall, R.D., and Phillips, F.M., 1997, Chronology of Pleistocene glacial advances in the central Rocky Mountains: Geological Society of America Bulletin, v. 109, p. 1443-1452, doi: 10.1130/0016-7606(1997)109<1443:COPGAI >2.3.CO;2.

Colman, S.M., Pierce, K.L., and Birkeland, P.W., 1987, Suggested terminology for Quaternary-dating methods: Quaternary Research, v. 28, p. 314-319, doi: 10.1016/0033-5894(87)90070-6.

Currey, D.R., 1974, Probable pre-neoglacial age of the type Temple Lake moraine, Wyoming: Arctic and Alpine Research, v. 6, p. 293-300, doi: $10.2307 / 1550065$. 
Dahms, D.E., 1991, Eolian Sedimentation and Soil Development on Moraine Catenas of the Wind River Mountains, West-Central Wyoming [Ph.D. dissertation]: Lawrence, University of Kansas, 340 p.

Dahms, D.E., 1993, Mineralogical Evidence for Eolian Sediments in Soils on Late Quaternary Moraines, Wind River Mountains, Wyoming: Geoderma, v. 59, p. 175-196, doi: 10.1016/0016-7061(93)90068-V.

Dahms, D.E., 2002, Glacial Stratigraphy of Stough Creek Basin, Wind River Range, Wyoming: Geomorphology, v. 42, p. 59-83, doi: 10.1016/S0169 -555X(01)00073-3.

Dahms, D.E., 2004a, Relative and Numeric Age-Data for Pleistocene Glacial Deposits and Diamictons in and Near Sinks Canyon, Wind River Range, Wyoming: Arctic, Antarctic, and Alpine Research, v. 36, no. 1, p. 59-76, doi: 10.1657/1523-0430(2004)036[0059:RANADF]2.0.CO;2.

Dahms, D.E., 2004b, Glacial Limits in the Middle and Southern Rocky Mountains, U.S.A., south of the Yellowstone Ice Cap, in Ehlers, J., and Gibbard, P.L., eds., Quaternary Glaciations-Extent and Chronology, Part II: North America: Amsterdam, Elsevier, Developments in Quaternary Science, v. 2b, p. 269-282 (map included on CD-ROM; scale 1:1,000,000).

Dahms, D.E., and Birkeland, P.W., 2000, Glacial Stratigraphy of Stough Creek Basin, Wyoming and a Latest Quaternary glacial and periglacial stratigraphy for the Wind River Range: Geological Society of America Abstracts with Programs, v. 32, no. 7, p. A-16.

Dahms, D.E., Hall, R.D., Shroba, R.R., Sorenson, C.J., Lynch, E.A., and Applegarth, M.T., 2003. The Rocky Mountain glacial model: The Wind River Range, Wyoming, in Easterbrook, D.J., ed., Quaternary Geology of the United States, INQUA 2003 Field Guide Volume: Reno, Nevada, Desert Research Institute, p. 345-364.

Davis, P.T., 1988, Holocene glacier fluctuations in the America cordillera: Quaternary Science Reviews, v. 7, p. 129-157, doi: 10.1016/0277-3791 (88) $90003-0$

Davis, P.T., Gosse, J.C., Romito, M., Sorenson, C., Klein, J., Dahms, D., Zielinski, G., and Jull, A.J.T., 1998, Younger Dryas Age for Type Titcomb Basin and Type Temple Lake moraines, Wind River Range, Wyoming, USA: Geological Society of America Abstracts with Programs, v. 30, no. 7, p. A-66.

Denton, G.H., 1975, Glaciers of the American Rocky Mountains, in Field, W.O., ed., Mountain glaciers of the Northern Hemisphere, Vol. 1: Cold Regions Research and Engineering Laboratory, Hanover, New Hampshire, p. 509-542.

Fall, P.L., Davis, P.T., and Zielinski, G.A., 1995, Late Quaternary vegetation and climate of the Wind River Range, Wyoming: Quaternary Research, v. 43, p. 393-404, doi: 10.1006/qres.1995.1045.

Frost, B.R., and Frost, C.D., 1993, The Archean history of the Wyoming Province, in Snoke, A.W., Steidtmann, J.R., and Roberts, S.M., eds., Geology of Wyoming: Geological Survey of Wyoming Memoir 5, p. 58-76.

Frost, B.R., Chamberlain, K.R., Swapp, S., Frost, C.D., and Hulsebosch, T.P., 2000, Late Archean structural and metamorphic history of the Wind River Range: Evidence for a long-lived active margin on the Archean Wyoming craton: Geological Society of America Bulletin, v. 112, p. 564-578, doi: 10.1130/0016-7606(2000)112<0564:LASAMH>2.3.CO;2.

Giardino, J.R., Shroder, J.F., and Vitek, J.D., eds., 1987, Rock Glaciers: Boston, Allen and Unwin, 355 p.

Gosse, J.C., Evenson, E.D., Klein, J., Lawn, B., and Middleton, R., 1995a, Precise cosmogenic ${ }^{10} \mathrm{Be}$ measurements in western North America: Support for a global Younger Dryas cooling event: Geology, v. 23, p. 877-880, doi: 10.1130/0091-7613(1995)023<0877:PCBMIW>2.3.CO;2.

Gosse, J.C., Klein, J., Evenson, E.B., Lawn, B., and Middleton, R., 1995b, Beryllium-10 dating of the duration and retreat of the last Pinedale glacial sequence: Science, v. 268, p. 1329-1333, doi: 10.1126/science .268.5215.1329.

Gosse, J., Davis, P.T., Burr, G., Jull, T., Bozarth, S., Sorenson, C., Klein, J., Lawn, B., and Dahms, D., 1999, Late Pleistocene/Holocene Glacial and Paleoclimatic History of Titcomb Basin, Wind River Range, Wyoming based on lake sediments and cosmogenic nuclide dating: Geological Society of America Abstracts with Programs, v. 31, no. 7, p. A-56.

Gosse, J.C., Evenson, E.B., Klein, J., and Sorenson, C., 2003, Cosmogenic nuclide glacial geochronology in the Wind River Range, Wyoming, in Easterbrook, D.J., ed., Quaternary Geology of the United States, INQUA 2003 Field Guide Volume: Reno, Nevada, Desert Research Institute, p. 49-56.

Granger, H.C., McKay, E.J., Mattick, R.E., Patten, L.L., and McIlroy, P., 1971, Mineral resources of the Glacier Primitive Area, Wyoming: U.S. Geological Survey Bulletin 1319-F.
Hack, J.T., 1943, Antiquity of the Finley site: American Antiquity, v. 8, p. 235245, doi: $10.2307 / 275903$

Hulsebosch, T.P., 1993, Aspects of crustal evolution in the Archean Wind River Range, Wyoming [Ph.D. dissertation]: Laramie, Wyoming, Department of Geology and Geophysics, University of Wyoming, 153 p.

Lal, D., 1991, Cosmic ray labeling of erosion surfaces: In situ nuclide production rates and erosion models: Earth and Planetary Science Letters, v. 104, p. $424-439$.

Locke, W.W., III, Andrews, J.T., and Webber, P.J., 1980, A manual for lichenometry: British Geomorphological Research Group, Technical Bulletin $26,47 \mathrm{p}$

Lowham, H.W., 1988, Streamflows in Wyoming: U.S. Geological Survey Water Resources Investigations Report 88-4045, 78 p.

Mahaney, W.C., 1972, Audubon: New name for Colorado Front Range neoglacial deposits formerly called "Arikaree": Arctic and Alpine Research, v. 4, p. 355-357, doi: 10.2307/1550276.

Mahaney, W.C., 1978, Late-Quaternary stratigraphy and soils in the Wind River Mountains, western Wyoming, in Mahaney, W.C., ed., Quaternary soils: Norwich, England, Geo Abstracts, p. 223-264.

Mahaney, W.C., 1984a, Superposed neoglacial and late Pinedale (Wisconsinan) tills, Titcomb Basin, Wind River Mountains, western Wyoming: Palaeogeography, Palaeoclimatology, Palaeoecology, v. 45, p. 149-163, doi: 10.1016/0031-0182(84)90038-5.

Mahaney, W.C., 1984b, Indian Basin advance in western and north-central Wyoming: Northwest Science, v. 58, p. 94-102.

Mahaney, W.C., 1987, Tentative growth curve for Rhizocarpon geographicum s.l. in Stroud Basin, Wind River range, western Wyoming: Northwest Science, v. 61, p. 13-19.

Mahaney, W.C., 1988, Comments on "Late Pleistocene age of the Type Temple Lake moraine, Wind River Range, Wyoming, U.S.A." by G.A. Zielinski and P.T. Davis: Geographie physique et Quaternaire, v. 42, p. 337-342.

Mahaney, W.C., and Halvorson, D.L., 1986, Rates of mineral weathering in the Wind River Mountains, western Wyoming, in Colman, S.M., and Dethier, D.P., eds., Rates of chemical weathering of rocks and minerals: New York, Academic Press, p. 147-167.

Mahaney, W.C., Boyer, M.G., Halvorson, D.L., and Sanmugadas, K., 1984a, Glacial chronology of the Rocky Mountains: Some problems in western Wyoming, in Mahaney, W.C., ed., Correlation of Quaternary Chronologies: Norwich, England, Geo Books, p. 225-241.

Mahaney, W.C., Halvorson, D., Piegat, J., and Sanmugadas, K., 1984b, Evaluation of dating methods used to assign ages in the Wind River and Teton Ranges, western Wyoming, in Mahaney, W.C., ed., Quaternary dating methods: New York, Elsevier Science Publishers Co. Inc., p. 355-374.

Marston, R.A., Pochop, L.O., Kerr, G.L., Varuska, M.L., and Veryzer, D.J., 1991, Recent glacier changes in the Wind River Range, Wyoming: Physical Geography, v. 12, p. 115-123.

Mears, B., 1974, The evolution of the Rocky Mountain Glacial Model, in Coates, D.R., ed., Glacial Geomorphology: State University of New York-Binghamton, p. 11-40.

Meier, M.F., 1951, Glaciers of the Gannett Peak-Fremont Area, Wyoming [M.S. thesis]: Ames, Iowa, Iowa State University, 159 p.

Meyer, G.A., Wells, S.G., and Jull, A.J.T., 1995, Fire and alluvial chronology in Yellowstone National Park: Climatic and Intrinsic Controls on Holocene geomorphic processes: Geological Society of America Bulletin, v. 107, p. 1211-1230, doi: 10.1130/0016-7606(1995)107<1211:FAACIY>2.3.CO;2.

Miller, C.D., and Birkeland, P.W., 1974, Probable pre-Neoglacial age for the type Temple Lake moraine, Wyoming: Discussion and additional relative-age data: Arctic and Alpine Research, v. 6, p. 301-306, doi: $10.2307 / 1550066$

Millspaugh, S.H., and Whitlock, C., 1995, A 750-year fire history based on lake sediment records in central Yellowstone National Park: The Holocene, v. 5, p. 283-292, doi: 10.1177/095968369500500303.

Millspaugh, S.H., and Whitlock, C., 2003, Postglacial fire, vegetation, and climate history of the Yellowstone-Lamar and Central Plateau provinces, Yellowstone national park, in Wallace, L., ed., After the Fires: The Ecology of Change in Yellowstone National Park: New Haven, Connecticut, Yale University Press.

Millspaugh, S.H., Whitlock, C., and Bartlein, P.J., 2000, Variations in fire frequency and climate over the last 17,000 years in central Yellowstone National Park: Geology, v. 28, p. 211-214, doi: 10.1130/0091-7613(2000)28<211:VIFFAC $>2.0 . C O ; 2$. 
Mock, C.J., and Brunelle-Daines, A.R., 1999, A modern analogue of western United States summer Paleoclimate at 6000 years before present: The Holocene, v. 9, p. 541-545, doi: 10.1191/095968399668724603.

Moss, J.H., 1949, Possible new glacial substage in the Middle Rocky Mountains [abs.]: Geological Society of America Bulletin, v. 60, p. 1972, doi: 10.1130/0016-7606(1949)60[1967:AOPPAM]2.0.CO;2.

Moss, J.H., 1951a, Early man in the Eden Valley (Wyoming): University of Pennsylvania Museum Monograph, v. 6, p. 6-92.

Moss, J.H., 1951b, Late glacial advances in the southern Wind River Mountains, Wyoming: American Journal of Science, v. 249, p. 865-883.

Naftz, D.L., 1993, Ice-core records of the chemical quality of atmospheric deposition and climate from mid-latitude glaciers, Wind River Range, Wyoming [Ph.D. thesis]: Golden, Colorado, Colorado School of Mines, 175 p.

Naftz, D.L., and Miller, K.A., 1992, USGS Collects Ice Core through Alpine Glacier: Eos (Transactions, American Geophysical Union), v. 73, p. 27, doi: 10.1029/91EO00024.

Naftz, D.L., and Smith, M.E., 1993, Ice Thickness, Ablation, and Other Glaciological Measurements on Upper Fremont Glacier, Wyoming: Physical Geography, v. 14, p. 404-414.

Naftz, D.L., Michel, R.L., and Miller, K.A., 1993, Isotopic Indicators of Climate in Ice Cores, Wind River Range, Wyoming, in Swart, P.K., Lohmann, K.C., McKenzie, J., and Savin, S., eds., Climate Change in Continental Isotopic Records: Geophysical Monograph 78, American Geophysical Union, p. 55-66.

Naftz, D.L., Susong, D.D., Schuster, P.F., Cecil, L.D., Dettinger, M.D., Michel, R.L., and Kendall, C., 2002, Ice core evidence of rapid air temperature increases since 1960 in alpine areas of the Wind River Range, Wyoming, United States: Journal of Geophysical Research, v. 107, no. D13, 4171, p. ACL1-ACL16, doi: 10.1029/2001JD000621.

North American Commission on Stratigraphic Nomenclature, 1983, North American stratigraphic code: The American Association of Petroleum Geologists Bulletin, v. 67, p. 841-875.

Pearson, R.C., Kiilsgaard, T.H., Patten, L.L., and Mattick, R.E., 1971, Mineral Resources of the Popo Agie Primitive Area, Fremont and Sublette Counties, Wyoming: Washington, D.C., U.S. Government Printing Office, U.S. Geological Survey Bulletin 1353-B.

Reheis, M.J., 1975, Source, transportation and deposition of debris on Arapaho Glacier, Front Range, Colorado: Journal of Glaciology, v. 14, p. 407-420.

Richmond, G.M., 1948, Modification of Blackwelder's sequence of Pleistocene glaciation in the Wind River Range, Wyoming: Geological Society of America Abstracts with Programs, v. 59, p. 1400-1401.
Richmond, G.M., 1957, Correlation of Quaternary deposits in the Rocky Mountain region, USA, V International Congress, International Association of Quaternary Research, Resumes Des Communications, Madrid-Barcelona, p. 157.

Richmond, G.M., 1962, Quaternary stratigraphy of the La Sal Mountains, Utah: U.S. Geological Survey Professional Paper 324, 135 p.

Richmond, G.M., 1965, Glaciation of the Rocky Mountains, in Wright, H.E., Jr., and Frey, D.G., eds., The Quaternary of the United States: Princeton, New Jersey, Princeton University Press, p. 217-230.

Richmond, G.M., 1986, Stratigraphy and correlation of glacial deposits of the Rocky Mountains, the Colorado Plateau and the ranges of the Great Basin: Quaternary Science Reviews, v. 5, p. 99-127.

Rodbell, D.T., 1992, Lichenometric and Radiocarbon Dating of Holocene glaciation, Cordillera Blanca, Peru: The Holocene, v. 2, p. 19-29.

Soil Survey Staff, 1999, Soil Taxonomy: U.S. Department of Agriculture Handbook no. 436, 2nd edition, 869 p.

Wahrhaftig, C., and Cox, A., 1959, Rock Glaciers in the Alaska Range: Geological Society of America Bulletin, v. 70, p. 383-436, doi: 10.1130/0016-7606(1959)70[383:RGITAR]2.0.CO;2.

Washburn, A.L., 1979, Geocryology: London, Edward Arnold, 406 p.

Whitlock, C.A., and Bartlein, P.J., 1993, Spatial Variations of Holocene Climatic Change in the Yellowstone region: Quaternary Research, v. 39, p. 231-238, doi: 10.1006/qres.1993.1026.

Whitlock, C.A., and Bartlein, P.J., 2004, Holocene Fire Activity as a record of past environmental change, in Gillespie, A.R., Porter, S.C., and Atwater, B.F., eds., The Quaternary Period in the United States: Elsevier, Developments in Quaternary Science 1, p. 479-490.

Zielinski, G.A., 1989, Lacustrine sediment evidence opposing Holocene rock glacier activity in the Temple Lake valley, Wind River Range, Wyoming, U.S.A: Arctic and Alpine Research, v. 21, no. 1, p. 22-33, doi: $10.2307 / 1551514$

Zielinski, G.A., and Davis, P.T., 1987, Late Pleistocene Age for the Type Temple Lake Moraine, Wind River Range, Wyoming, USA: Geographie Physique et Quaternaire, v. 41, p. 397-401.

Zielinski, G.A., and Davis, P.T., 1988, Reply to comments on "Late Pleistocene age of the type Temple Lake moraine, Wind River Range, Wyoming, U.S.A.”: Geographie physique et Quaternaire, v. 42, p. 340-342.

Zielinski, G.A., and Davis, P.T., 1989, Handout for self-guided trip to Temple Lake Valley: High country portion of Field Trip to Wind River Mountains, Wyoming: Friends of the Pleistocene, Rocky Mountain Cell.

Manuscript Accepted by the Society 20 June 2009 